QL:

508

$S B$

$\$ 3$

\title{
U.C.I.
}

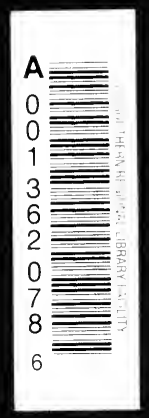




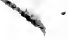 \\ LIBRARY \\ University of California}

IRVINE 
? 





\title{
III.
}

\section{THE NORTH AMERICAN CEUTHOPHILI.}

\author{
By Samuel H. Scudder.
}

Presented May 9, 1894

The Ceuthophili are wingless Locustarians in which the tarsi are distinctly compressed rather than depressed, with no pulvilli,* the hind tibiæ furnished on the outer margins above with spines of two distinct grades, $\uparrow$ the fore femora without foramina or genicular spines, the hind femora with the angle of their insertion on the inner and not on the outer side beneath, and the antennæ strongly approximated at base: They are all apterous.

With the exception of the genus Troglophilus Krauss, with two species from European caverns, and the genus Talitropis Bol., with a single species from New Zealand, placed respectively at one and the other end of the series, they are known only from America; and with the further exception of Heteromallus Brunner, with two species from Chili, they are all peculiar to the United States and Northern Mexico. Here they include six genera and sixty-seven species, the genus Ceuthophilus alone containing above fifty species. The larger proportion of them, if not all (excepting Udeopsylla nigra), frequent dark places, such as burrows, pits, caverns, wells, hollow trees, and especially the crevices beneath fallen logs.

They were first made known in this country by the descriptions of Haldeman, Girard, and Harris, and before their time only a single species from this country had been described, by Burmeister. Not a species of the group, even the European, was known to Serville. My first systematic paper, in 1861, was a study of "Rhaphidophora" (Proc. Bost. Soc. Nat. Hist., VIII.) where seven of our species were

* Brunner states that Gammarotettix has a single pulvillus on the first tarsal joint; but although the treading surface of this joint (as of the succeeding) is broad, I can find no indication of a true pulvillus.

$\dagger$ This feature is obscure in Gammarotettix, where there are alternating longer and shorter spines of such slight inequality as easily to be overlooked, and which in the Table of Genera given below is ignored.

vol. $x \times x \cdot($ N. s. $x \times 11$ ) 
described or catalogued; but their diversity was hardly fully recognized when in the following year I published my Materials for a Monograph of the Forth American Orthoptera (Bost: Journ. Nat. Hist., VII.), where eighteen species and five genera were characterized or indicated; since then a few more species have been described, by 'Thomas, Brunner, Bruner, Packard, Walker, Blatchley, and myself, until now the number of nominal species is twenty-eight, which must, however, be reduced by synonymy and by reference to other genera to twenty.

In 1888, Brunner, in his Monographie der Stenopelmatiden und Gyllacriden (Verh. Zool.-bot. Gesellsch. Wien), subjected all the species known to him to systematic treatment; but as the larger part of our species and some of our genera were unknown to him, and the number of separately described species has multiplied so greatly while still not including, at least in Ceuthophilus, the half of our species, it has seemed desirable to undertake a revision of the group, so far as our native species are concerned, and in the genus Ceuthophilus to redescribe all the older forms, as well as to publish the noyelties. Accordingly in the present paper thirty-eight additional species of the group are characterized, together with a new genus, while $I$ shall further show the validity of Daihinia of Haldeman, which has been called in question by Brunner, and shall point out first that one of the genera thought to belong here should be separated as a member of a distinct group. The total number of genera from North America is therefore six, and of the species sixty-seven, while a number of other species are known to me imperfectly by a single sex or poor examples.

\section{TROPIDISCHIA Scudder.}

Tropidischia Scudd., Bost. Journ. Nat. Hist., vii. 440-441 (1862).

In his Monograph of the Stenopelmatidæ, Brunner von Wattenwyl, from the insufficient data given in my two statements regarding the structure of this creature, incorrectly surmised that this genus should be placed in the Ceuthophili, and was perhaps congeneric with Heteromallus, a Chilian genus. Since, however, the hind tibiæ are supplied above with spines of one grade only, it is plainly more nearly related to the Dolichopodæ, from which it may be distinguished by the similarly spined margins of the under surface. It seems to form a group apart, between the Dolichopodx and Ceuthophili, and of equivalent value. It appears to come nearer Hadenœcus and Dolichopoda than to any other described genera. 
In addition to the characters mentioned above and those given in previous descriptions, I may add that all the legs are tetraquetrous, with all the margins spined, the spines similar in character and uniformly crowded, excepting on the lower margins of the fore femora, the inner carina of which is sparsely spined, the outer carina unarmed; also the lower margins of the middle femora, both carinæ of which are sparsely spined on the apical half; and the hind femora, the four carinæ of which, even on the swollen portion, are armed excepting at the extreme base, though both the inferior carinæ are rather sparsely spined. There are no spines on the genicular lobes of the femora, excepting a very slight one on the posterior side of the middle femora. There are but two pair of calcaria on the hind tibiæ, the upper the longer and less than half as long as the first tarsal joint. The hind tarsi are very strongly compressed, carinate beneath without pulvilli, about two fifths as long as the hind tibiæ, the first joint nearly as long as the remaining joints together, the second and fourth joints of the same length and either of them three times as long as the third. Finally, the subgenital lamina of the male is ample, the hind margin entire, with minute styles, consisting of a single bluntly conical joint; and the ovipositor is slender, gently arcuate, tapering and acuminate, unarmed at tip.

\section{Tropidischia xanthostoma.}

Rhaphidophora xanthostoma Scudd.!, Proc. Bost. Soc. Nat. Hist., viii. 12 (1861).

Tropidischia xanthostoma Scudd.!, Bost. Journ. Nat. Hist., vii. 441 (1862).

Originally described from Crescent City, Cal. (A. Agassiz). I have since received both sexes from Mendocino, Cal., through the favor of Mr. J. Behrens. 


\section{Table of the Genera of Ceuthophili.}

$a^{1}$. Last palpal joint cleft apically on the under side. Descending lobes of the mesonotum but little longer than those of the pronotum; sides of fore and middle coxæ externally laminate, the lamination elevated to a denticle or compressed spine either mesially or (on middle legs) apically, occasionally (Hadenœcus) wanting on middle legs. Fore tibiæ not sulcate above; hind tibiæ with spines of two grades on both outer and inner margins of upper surface. Outer valves of ovipositor unarmed above before the apex.

$b^{1}$. Palpi long. Hind tibiæ usually considerably longer than the hind femora. Third hind tarsal joint only half or less than half as long as the second.

$c^{1}$. Vertex obscurely bituberculate at apex. Last palpal joint no longer or scarcely longer than the third, and cleft beneath only apically. Middle coxæ unarmed. Middle femora with a feeble genicular spine on posterior margin. Hind tibiæ with more than four pairs of spurs. First hind tarsal joint almost as long as the others together. Subgenital plate of male triangular and rather deeply and narrowly emarginate . . . Hadencecus. $c^{2}$. Vertex not tuberculate. Last palpal joint distinctly longer than the third, cleft beneath for almost its entire length. Middle coxæ spined mesially. Middle femora with a distinct genicular spine on posterior margin. Hind tibiæ with only four pairs of spurs. First hind tarsal joint generally a third shorter than the rest combined. Subgenital plate of male ample and broadly emarginate . . . . . . . . . . . Ceuthophilus.

$b^{2}$. Palpi short. Hind tibiæ shorter or at most but little longer than the hind femora. Third hind tarsal joint hardly shorter than the second, or (in Daihinia) wanting. (Lamination of middle coxæ produced inferiorly to the semblance of a spine.)

$c^{1}$. Third palpal joint as long as fifth, the inferior cleft of the latter extending over only the apical half. Middle femora unarmed at tip or with a very feeble spine. Hind tibiæ shorter or at least no longer than the hind femora, with few spines of the second grade on the upper surface, those of the first grade relatively numerous, at least in the $\&$, more or less irregularly placed and of unequal length; the calcaria three in number on each side, the uppermost generally a little the longest and unusually distant from the extreme apex, so as to appear rather as an addi- 
tional pair of spurs. Subgenital plate of male greatly produced and apically deeply fissured.

$d^{1}$. Descending lobes of mesonotum slightly longer than those of prouotum. Last tarsal joint very much shorter than the remaining joints together, the third joint normal, though but little shorter than the second. Subgenital plate of male ample, rather deeply and broadly emarginate, the sides extending backwards as slender threads . . . . Phrixocnemis. $d^{2}$. Descending lobes of mesonotum no longer than those of pronotum. Last tarsal joint about as long as the rest together; third tarsal joint wanting (as also on fore legs). Subgenital plate of male immensely produced and so deeply fissured as to form two tapering ribbons . . . . . . . Daihinia. $c^{2}$. Third palpal joint shorter than the fifth, the inferior cleft of the latter extending its whole length. Middle femora with a genicular spine on posterior side. Hind tibia slightly longer than the hind femora, with numerous spines of the second grade uniform in length and pretty regularly separated; calcaria three in number on each side, the middle one much longer than the others. (First hind tarsal joint a third shorter than the rest combined.) Subgenital plate of male ample, apically bituberculate . . . . . . . . . . . . . . Udeopsylla. $a^{2}$. (Vertex bituberculate. Palpi short), the last joint apically with no inferior cleft. Descending lobes of mesonotum considerably longer than those of pronotum; sides of fore and middle coxæ neither caridate nor spined. (Fore and middle femora unarmed.) Fore tibiæ sulcate above; hind tibix (of the same length as the hind femora) with only one grade* of spines above on the lateral margins; (calcaria two in number on each side, subequal and not long. Third hind tarsal joint half as long as the second. Subgenital plate of male ample, apically broadly and not deeply emarginate); outer valves of ovipositor serrate above before the apex . . . . . Gammarotettix.

* See introductory remarks. 


\section{HADENGECUS ScUdDER.}

Hadenœcus Scudd., Bost. Journ. Nat. Hist., vii. 439-440 (1862); Brunn., Monogr. Stenop., 66 (1888).

\section{Table of the Species of Hadenocus.}

Body pale testaceous. Ovipositor nearly or quite as long as the body. Subgenital plate of $\hat{\delta}$ broadly emarginate at apex.

cavernarum.

Body dark brown. Ovipositor only half as long as the body. Subgenital plate of $\delta$ narrowly emarginate at apex . . putearus.

\section{Hadengcus cavernarum.}

Phalangopsis sp. Thomps., Ann. Mag. Nat. Hist., xiii. 113 (1844).

Rhapidophora cavernarum Sauss., Ann. Soc. Entom. France (4), i. 492 (1860).

Hadenœcus cavernarum Scudd.!, Proc. Bost. Soc. Nat. Hist., xii. 409 (1869); xix. 38 (1877); Boliv., Ann. Soc. Ent. France (5), x. 72 (1880); Riley, Stand. Nat. Hist., ii. 184, fig. 260 (1884); Comst., Intr. Ent., 114 (1888); Blatchl., Proc. Ind. Acad. Sc., 1892, 153.

Rhapidophora subterranea Scudd.!, Proc. Bost. Soc. Nat. Hist., viii. 8 (1861) ; Pack., Amer. Nat., v. 745, fig. 126 (1871) ; Cope, Ibid., vi. 409 (1872) ; Hubb., Amer. Ent., iii. 37 (1880).

Hadenøecus subterraneus Scudd.!, Bost. Journ. Nat. Hist., vii. 441 (1862) ; Walk., Catal. Derm. Salt. Brit. Mus., i. 201 (1869) ; Pack., Guide Ins., 565 (1869) ; Glover, Ill. N. A. Ent., Orth., pl. 8, fig. 6 (1872) ; Cope-Pack., Amer. Nat., xv. 882 (1881) ; Brunn., Monogr. Stenop., 66, fig. 34 (1888); Pack., Mem. Nat. Acad. Sc., iv. 67-70, 83,116, fig. 16, pl. 17, fig. 3 (1888) ; Id., Psyche, v. 198-199 (1889); Garm., Ibid., vi. 105, fig. (1891).

Early notices of this insect by Telkampf will be found in Mûller's Arch. Anat. Phys., 1844, 318, and Wiedemann's Arch. Naturg., 1844, 384 ; also by Schiödte in K. Danske Vid. Selsk. Skrift. 1849, 5 ; by Agassiz in Silliman's Amer. Journ. Sc., 1851, 127; and by Lesquereux in the Actes Soc. Helv. Sc. Nat., 40 Sess., 52-53 (1855).

I have studied specimens only from the Mammoth Cave, Ky. It is also reported by Packard from many other caves in the Mammoth Cave region, as Dixon's, White's, Salt, Ice, Diamond, Grand Avenue, Poynter's, Wetzel's, Haunted, and Emerson Spring Branch caves; besides Mail Robbers', One Hundred Dome, Walnut Hill Spring, 
Short, Proctor's, Little Lithographic, and Sugar Bowl caves, and a cave under Gardiner's Knob, - all near Glasgow Junction; also a cave near Baker's Furnace, and John and Fred's Cave on the east bank of Dismal Creek; further in Carter County caves, viz. Gray Tom's, Zwingle's, Bat, Van Meter's, Grayson Springs, and Burchell's caves; and finally in Nickajack Cave, Tenn. Blatchley also reports it from Wyandotte Cave, Ind., on the authority of Cope, but it is not so given by Cope in the references quoted; and Walker, of course in error, from the "west coast of America"! I have also seen specimens in the Museum of Comparative Zoölogy, Cambridge, from Turner's Caves, Pennington Gap, Lee County, Va. (H. G. Hubbard), and Ely Cave, Lee County, Va. (N. S. Shaler).

\section{Hadengcus puteanus.}

Hadenøecus puteanus Scudd.!, Proc. Bost. Soc. Nat. Hist., xix. 37 (1877).

On sides and under covering of wells in North Carolina; also in Mississippi.

\section{CEUTHOPHILUS ScUdDER.}

Ceuthophilus Scudd., Bost. Journ. Nat. Hist., vii. 433-434 (1862); Brunn., Monogr. Stenop., 61 (1888).

This is one of the dominant American genera of Locustarix, confined to North America and almost entirely to the United States, embracing a large number of species in every section of the country, of which fifty-five are here characterized. Several others are known to me by single specimens or mutilated examples. The following table is based principally upon the males. It has been impossible to construct it so as to bring together the allied species, whose relationship is better shown by the order in which they are described, though even here the arrangement is far from satisfactory, nearly allied species being sometimes separated at considerable distances in order to bring them in closer relation with other allies. Although $I$ have had six hundred and fifty examples to study at this time, besides others in alcohol, the material is still insufficient to make a satisfactory disposition of our species, and I am confident that very many more yet remain to be discovered. 


\section{Table of the Species of Ceuthophilus.}

$a^{1}$. Second joint of hind tarsi at least half as long again, usually twice or more than twice as long, as the third.

$b^{1}$. Fore femora one third or more than one third longer than the pronotum, at least in the $\delta$; hind tibiæ of $\delta$ almost always straight, never greatly bowed.

$c^{1}$. Hind tibiæ of $\delta$ at least a tenth longer than the hind femora.

$d^{1}$. Ovipositor much shorter than the fore femora.

$e^{1}$. Hind femora stout, not three times as long as broad, at least in the $\delta$. . . . . . 1. variegatus. $e^{2}$. Hind femora slender, four times as long as broad in the \&. . . . . . . . . . 2. ensifer. $d^{2}$. Ovipositor much longer than the fore femora.

$e^{1}$. Hind tibial spurs less than twice as long as the tibial depth ; outer carina of hind femora of $\delta$ generally with some spines at least half as long as the tibial spurs.

$f^{1}$. Fore femora of $\delta$ three fourths as long again as the pronotum . . . . . . . . . 3. stygius. $f^{2}$. Fore femora of $\delta$ from one half to two thirds as long again as the pronotum.

$g^{1}$. Hind femora of $\delta$ much less than four times as long as broad; hind tibiæ of $\delta$ very long and more or less sinuous at base in old individuals.

$h^{1}$. Largest spines of outer carina of hind femora of $\delta$ simple and similar to the others.

4. gracilipes.

$h^{2}$. Largest spines as above greatly tumid at base.

5. latebricola.

$g^{2}$. Hind femora of $\delta$ much more than four times as long as broad; hind tibiæ of $\delta$ scarcely more than one tenth longer than the hind femora, straight.

6. grandis.

$e^{2}$. Hind tibial spurs fully twice, generally much more than twice, as long as tibial depth; outer carina of hind femora of $\delta$ with no spines a third as long as the tibial spurs.

$f^{1}$. Armature of outer carina of hind femora of $\delta$ developed as distinct spines rather than as serrations; ovipositor arcuate . . . . . . 7. secretus. 
$f^{2}$. Armature of outer carina of hind femora of $\delta$ developed only as recumbent serrations; ovipositor almost or quite straight.

$g^{1}$. Hind femora of $\delta$ slender, almost or quite four times as long as broad; hind tibiæ exceptionally long, nearly or quite one sixth longer than the femora.

$h^{1}$. Hind femora of $\delta$ more than twice as long as the fore femora; ovipositor very feebly arcuate, only two thirds as long as the hind femora.

8. palmeri.

$h^{2}$. Hind femora of $\delta$ less than twice as long as the fore femora; ovipositor straight, three fourths as long as the hind femora . . . 9. corticicola. $g^{2}$. Hind femora of $\delta$ less slender, being less than three and three quarters times as long as broad; hind tibiæ but little more than one tenth longer than the femora . . . . . . . 10. varicator.

$c^{2}$. Hind tibiæ of $\delta$ distinctly less than a tenth longer than the hind femora; ovipositor always longer than the fore femora.

$d^{2}$. Hind tibiæ of $\delta$ straight; outer carina of hind femora of $\delta$ never conspicuously spined.

$e^{1}$. Hind tibial spurs nearly three times as long as the tibial depth . . . . . . . . . . 11. latibuli. $e^{2}$. Hind tibial spurs at most less than twice as long as the tibial depth, rarely half as long again.

$f^{1}$. Prevailing colors blackish fuscous above, the lighter colors being distinctly less extensive than the dark (which is generally nearly black) and appearing as dots or roundish spots, and sometimes also as a broad mediodorsal stripe.

$g^{1}$. Fore femora of $\delta$ at most scarcely more than a third longer than the pronotum; outer carina of hind femora of $\delta$ serrulate, not spined.

$h^{1}$. Hind femora relatively long and slender, three and three quarters times as long as broad.

12. seclusus.

$h^{2}$. Hind femora relatively stout, not over three and a half times longer than broad.

$i^{1}$. Hind tibiæ but little longer than the femora, the spurs not longer than the tibial depth, the hind femora considerably more than twice as long as the fore femora. 
$j^{1}$. Hind femora less than three times as long as broad . . . . . . . 13. terrestris.

$j^{2}$. Hind femora three and a half times as long as broad . . . . . 14. celatus.

$i^{2}$. Hind tibiæ considerably longer than the femora, the spurs half as long again as the tibial depth, the hind femora only about .twice as long as the fore femora . . . . . 15. brevipes.

$g^{2}$. Fore femora of $\delta$ nearly one half longer than the pronotum ; outer carina of hind femora of male spined, not serrulate. . . . . 16. lapidicola. $f^{2}$. The lighter colors which are more massive prevail above, the darker appearing principally as posterior bands to the segments and rarely darker than fuscocastaneous, rarely with a light mediodorsal line.

$g^{1}$. Outer carina of hind femora of $\delta$ armed with only a few raised points.

$h^{1}$. Hind femora slender, nearly three and a half times longer than broad . . 17. arizonensis. $h^{2}$. Hind femora stout, about two and a half times longer than broad ... . . 18. uniformis.

$d^{2}$. Hind tibiæ of $\delta$ arcuate or sinuous; outer carina of hind femora of $\delta$ always conspicuously spined.

$e^{1}$. Hind femora very long, four times as long as broad, the fore femora fully three fourths as long again as the pronotum . . . . . . . . . . 19. heros. $e^{2}$. Hind femora relatively short, not more than three and a half times longer than broad, the fore femora considerably less than half as long again as the pronotum.

$f^{1}$. Inferior sulcus of hind femora of $\delta$ broadening proximally . . . . . . . . 20. uhleri. $f^{2}$. Inferior sulcus of hind femora of $\delta$ of uniform width . . . . . . . . 21. blatchleyi.

$b^{2}$. Fore femora but little if any longer than the pronotum even in the male; hind tibiæ of male usually straight, but often bowed or sinuate.

$c^{1}$. Dorsal surface of abdomen of $\delta$ smooth and even.

$d$. Hind tibiæ of $\delta$ arcuate or sinuate in basal half.

$e^{1}$. Hind tibiæ of $\delta$ considerably longer than the femora; hind tibial spurs usually at least half as long again as the tibial depth. 
$f^{1}$. Hind femora of $\delta$ relatively long, three and a half times as long as broad; no large spines on outer carina.

30. maculatus.

$f^{2}$. Hind femora of $\delta$ relatively stout, rarely exceeding three, never three and a quarter, times as long as broad; some spines on outer carina as long as the tibial spurs.

$g^{1}$. Hind tibiæ of $\delta$ at least a tenth longer than the femora.

$h^{1}$. Hind femora of $\delta$ two and a half times longer than the fore femora; hind tibial spurs only slightly longer than the tibial depth.

28. meridionalis.

$h^{2}$. Hind femora of $\delta$ but little more than twice as long as the fore femora; hind tibial spurs nearly twice as long as the tibial depth . 45. inquinatus.

$g^{2}$. Hind tibiæ of $\delta$ less than one tenth longer than the femora . . . . . . . . 22. spinosus. $e^{2}$. Hind tibix of $\delta$ at most scarcely longer than the femora; hind tibial spurs rarely longer than the tibial depth.

$f^{1}$. Hind femora of $\delta$ three or more than three times as long as broad; fore femora nearly or quite a fifth longer than the pronotum.

$g^{1}$. Hind tibiæ of $\delta$ at most feebly sinuate at base.

39. agassizii.

$g^{2}$. Hind tibiæ of $\delta$ very strongly bowed.

34. valyus.

$f^{2}$. Hind femora of $\delta$ less than three times as long as broad; fore femora only an eighth longer than the pronotum.

$g^{1}$. Hind tibiæ of $\delta$ strongly bowed, armed below with a row of spines mounted on nodules.

33. nodulosus.

$g^{2}$. Hind tibiæ of $\delta$ faintly sinuate at base, normally armed beneath . . . . . . 51. latipes.

$d^{2}$. Hind tibiæ of $\delta$ straight throughout.

$e^{1}$. Outer carina of hind femora of $\delta$ armed with prominent conical spines, generally well separated.

$f^{1}$. Hind tibix of $\delta$ less than one tenth longer than the femora.

$g^{1}$. Dorsal surface of body almost uniformly very dark, almost black, the lighter markings themselves 
not very light nor extensive, and therefore inconspicuous.

$h^{\mathbf{1}}$. Hind tibial spurs generally excessively divergent, extending in nearly opposite directions on the two sides and set at a high angle with the tibia.

35. divergens.

$h^{2}$. Hind tibial spurs rarely exceeding $120^{\circ}$ in divergence, and set at an angle with the tibia not exceeding $50^{\circ}$.

$i^{1}$. Smaller species, with pallid sides, luteous legs, and narrow dorsal stripe, the hind tibiæ of the $\delta$ a twelfth as long again as the femora.

23. cacus.

$i^{2}$. Larger species, with castaneous sides and legs and broad dorsal stripe, the hind tibiæ of $\delta$ not a thirtieth longer than the femora - 26. sallei. $g^{2}$. Dorsal surface of body with conspicuously contrasted dark and light markings, neither prevailing over the other . . . . . . 47. pallidus. $f^{2}$. Hind tibiæ of $\delta$ a tenth longer than the femora.

32. bicolor.

$e^{2}$. Outer carina of hind femora of $\delta$ more or less delicately serrate or armed with recumbent spines.

$f^{1}$. Body of male very compact, short subfusiform, not or hardly more than two and a quarter times as long as broad.

$g^{1}$. Hind femora of $\delta$ relatively stout, considerably less than three times as long as broad, the hind tibix longer than the femora, and the spurs only as long as the tibial depth . . . . . . 24. nigricans. $g^{2}$. Hind femora of $\delta$ relatively slender, three times as long as broad, the hind tibiæ shorter than the femora and the spurs nearly half as long again as the tibial depth . . . . . . . 25. fusiformis. $f^{2}$. Body of $\delta$ much more elongated, rarely distinctly fusiform, over three and generally at least four times as long as broad.

$g^{1}$. Hind tibiæ of $\delta$ at least a tenth longer than the femora.

$h^{1}$. Body without conspicuously contrasted colors; hind femora of $\delta$ relatively slender, four times as long as broad . . . . . . 36. occultus. 
$h^{2}$. Body with conspicuously contrasted colors; hind femora of $\delta$ relatively slender, less than three and a quarter times as long as broad . 46. discolor. $g^{2}$. Hind tibiæ of $\delta$ less than one tenth longer than the femora.

$h^{1}$. Hind femora of $\delta$ with no raised points on the upper distal half.

$i^{1}$. Outer carina of hind femora of $\delta$ almost unarmed; markings of the body more or less marmorate or maculate.

$j^{1}$. A broad continuous light dorsal stripe on pronotum, usually extending over the whole thorax.

$k^{1}$. Hind tibial spurs distinctly marked with black at base; ovipositor twice as long as fore femora . . . . 27. latens. $k^{2}$. Hind tibial spurs at most indistinctly infuscated at base; ovipositor shorter than fore femora . . . . 31. tenebrarum. $j^{2}$. A narrow and very unequal light dorsal stripe on pronotum, interrupted, if present, on rest of thorax . . . . . 38. bruneri. $i^{2}$. Outer carina of hind femora of $\delta$ finely and closely serrate; dark markings of body confined to transverse borderings of the segments.

48. vinculatus.

$h^{2}$. Hind femora of $\delta$ with a greater or less number of raised points on upper distal balf.

$i^{1}$. Hind femora of $\delta$ with only a few distant recumbent spines on outer carina.

$j^{1}$. Hind tibir of $\delta$ a tenth longer than the femora; spurs fully twice as long as tibial depth . . . . . . . . . 44. pinguis. $j^{2}$. Hind tibix of $\delta$ less than a tenth longer than the femora; spurs much less than twice as long as tibial depth . . 40. mexicanus. $i^{2}$. Hind femora of $\delta$ with numerous denticulations on the outer carina, forming a more or less close serration.

$j^{1}$. Ovipositor relatively short, at most but little more than half as long as hind femora. 
$k^{1}$. Hind femora of $\delta$ less than twice as long as fore femora.

$l^{1}$. Hind tibiæ of $\delta$ no longer than femora; spurs only a little longer than tibial depth, and divaricating about $60^{\circ}$; inner carina of fore femora minutely serratulate . . . 50. culifornianus. $l^{2}$. Hind tibix of $\delta$ a little longer than femora; spurs fully twice as long as tibial depth, and divaricating about $90^{\circ}$; inner carina of fore femora simply spined.

49. testaceus.

$k^{2}$. Hind femora of $\delta$ two and a fourth times as long as fore femora . . 29. neglectus. $j^{2}$. Ovipositor relatively long, two thirds as long as hind femora or more.

$k^{1}$. Hind femora of $\delta$ relatively slender, at least three times as long as broad.

$l^{1}$. Hind tibiæ of $\delta$ of same length as femora; colors moderately dark.

37. alpinus.

$l$. Hind tibix of $\delta$ considerably longer than femora; colors rather pallid.

41. pallescens.

$k^{2}$. Hind femora of $\delta$ relatively siout, hardly more than two and a half times as long as broad . . . 43. crassus.

$c^{2}$. Dorsal surface of abdomen of $\delta$ closely tuberculate; hind tibiæ strongly arcuate.

$d^{1}$. Both outer and inner carinæ of hind femora of $\delta$ armed with a large compressed spine as long as the depth of the genicular lobes . . . . . . . . 52. pacificus. $d^{2}$. Outer carina of hind femora of $\delta$ elevated to a high lamina, suddenly terminating acutely before the genicular lobes . . . . . . . . . . . 53. henshawi. $a^{2}$. Second joint of hind tarsi but little longer than the third.

$b^{1}$. Large species; outer carina of hind femora considerably and uniformly elevated throughout . . . . . . 54. devius. $b^{2}$. Small species; ouier carina of hind femora elevated distally much more than proximally . . . . 55. neomexicanus.

The male being unknown to me, $C$, sylvestris does not appear in the above table. It will be found below as No. 41 . 


\section{Ceuthophilus variegatus, sp. nov.}

Blackish fuscous with a slight olivaceous tinge, marked with yellowish luteous; there is an interrupted dorsal stripe of the lighter color especially interrupted on the anterior half of the pronotum; this is heavily margined by subconfluent dark blotches or spots, and the dark color prevails over the rest of the thorax, with oblique patches of the lighter tints on the meso- and metanotum, irregular vermiculate blotches of greater or less extent on the pronotum and the lower edges of the descending lobes of the thorax margined not very narrowly with luteous; the sides of the abdomen are prevailingly luteous, but the anterior outer margins are mostly fuscous; the hind femora have the usual scalariform markings very pronounced, while the other legs are prevailingly luteous and much streaked with fuliginous, excepting the tarsi ; the longer spines are bright luteous, but black tipped. The antennæe are two or three times as long as the body, moderately stout at the base and gradually tapering, and the legs moderately short. Fore femora distinctly broader than the middle femora, nearly half as long again $(\delta)$ or scarcely a fourth as long again ( $q$ ) as the pronotum, and less than half as long as the hind femora, the inner carina with three long spines, the distal subapical and very long. Middle femora with 2-3 long spines on the front carina, one subapical and very long, and on the hind carina 1-2 long spines besides a long genicular spine. Hind femora slightly ( $\delta$ ) or considerably (\$) more than twice as long as the fore femora, very broad and stout, distinctly less than three times as long as broad especially in the male, a few very distant and scattered raised points over the whole apical half of the surface, excepting beneath and especially on the inner side above, the outer carina with 3-4 very unequal spines in the apical half, one, sometimes two, much larger than the rest, coarse and as long as the tibial spurs $(\delta)$ or with a single inconspicuous spine in the pregenicular sinus ( $q$ ), the inner carina with half a dozen small uniform but irregularly distant spinules, the intervening sulcus rather narrow. Hind tibiæ straight in both sexes, moderately slender, scarcely expanded distally, distinctly but not greatly longer than the femora, armed beneath with a single subapical spine besides the apical pair; spurs subalternate, the basal before the end of the proximal fourth of the tibia, half as long again as the tibial depth. set at an angle of $40-45^{\circ}$ with the tibia and divaricating about $50-60^{\circ}$, their tips considerably incurved; inner middle calcaria a little larger than the outer, twice as long as the others or as the spurs, and nearly as long as the first tarsal 
joint. Hind tarsi considerably less than half as long as the tibia, the first joint unusually prolonged below and as long as the rest together, the second fully twice as long as the third and with it as long as the fourth. Cerci moderately stout, regularly tapering, as long as the pronotum. Ovipositor very short, not so long as the pronotum, rapidly tapering at base, beyond slender, the armature of the inner valves consisting of moderately stout but rather prominent bluntly pointed spines.

Length of body, \& $15 \mathrm{~mm}$., $\$ 19 \mathrm{~mm}$; antennæ (est.), ठ $30+$ mm., $\$ 45+\mathrm{mm}$.; pronotum, of $5.5 \mathrm{~mm}$., $\$ 6.5 \mathrm{~mm}$.; fore femora, के $8 \mathrm{~mm}$., \& $7.75 \mathrm{~mm}$; hind femora, of $16.75 \mathrm{~mm}$., $\& 17.75 \mathrm{~mm}$.; hind tibie, of $19 \mathrm{~mm}$., $\$ 18.5 \mathrm{~mm}$; ovipositor, $6 \mathrm{~mm}$.

2 \& 2 \%. Matamoras, Tamaulipas, Mexico, L. B. Couch; Ringgold Barracks at the lower end of the Rio Grande, C. A. Schott; Carrigo Springs, Texas, A. Wadgymar, through L. Bruner.

\section{Ceuthophilus ensifer.}

Ceuthophilus ensifer Pack.!, Amer. Nat., xv. 882, pl. 7, figs. 4, 4ab (1881); Id.!, Mem. Nat. Acad. Sc., iv. 71-72, 83, figs. 17, 17ab (1888); Blatchl., Proc. Ind. Acad. Sc., 1892, 153 (1894).

Body luteo-testaceous, heavily marked with blackish fuscous, which broadly borders all the abdominal segments posteriorly and inferiorly, as it does also (but more or less broken mediodorsally) the thoracic; there are also two large subdorsal anterior blackish fuscous spots on the meso- and metanotum, and the pronotum has a large $\mathrm{T}$-shaped blackish median spot heavily mapped out with a basal expansion and which is cut by a mediodorsal luteous line, bordered on either side posteriorly by one, anteriorly by two luteous dots, transversely aligned; the inferior border is broadly margined with black, leaving in the middle of either side a large irregular luteous blotch more or less streaked with fuscons; the legs are castaneous, the hind femora with fuscous scalariform markings and apically broadly annulate with fuscous; the apical half of tibix and the tarsi pallid. The antennæ are about twice the length of the body and the legs long and slender. The fore femora are not stouter than the middle femora, nearly twice as long as the pronotum and somewhat more than half as long as the hind femora, the inner carina with 3-4 spines of considerable size. Middle femora with four spines on the front carina and on the hind carina three besides a moderately long genicular spine. Hind femora about as long as the body, somewhat less than twice as long as the fore femora, slender, the apical third subequal, the inferior margin 
nearly straight, the whole fully four times as long as broad, the dark portions of the surface, even of the inner side, with slight, equally distributed raised points but none independent of them, the outer carina ( $q$ ) with delicate distant spinules especially beyond the middle, the inner carina similarly armed, the intervening sulcus moderately narrow. Hind tibiæ considerably longer than the femora, slender, armed beneath with a single preapical spine besides the apical pair; spurs rudely opposite, the basal well beyond the end of the proximal third of the tibia, half as long again as the tibial depth, set at an angle of $35^{\circ}$ with the tibia and divaricating 90-100, their tips strongly incurved; inner middle calcaria considerably longer than the outer, much more than twice as long as the others or as the spurs, but much shorter than the first tarsal joint. Hind tarsi almost half as long as the tibiæ, the first joint as long as the rest together, the second almost three times as long as the third and with it longer than the fourth. Cerci tapering throughout, finely pointed, half as long again as the femoral breadth. Ovipositor hardly three quarters as long as the fore femora, stout in basal third, tapering in middle third, slender and subequal in distal third, the apex produced and slightly upturued, the inner valves with eight sharp but slight serrations.

Length of body, $919.5 \mathrm{~mm}$. ; pronotum, $5.2 \mathrm{~mm}$; fore femora, 10 mm.; hind femora, $18.75 \mathrm{~mm}$; hind tibiæ, $20.25 \mathrm{~mm}$; ovipositor, $7 \mathrm{~mm}$.

2 \&. Nickajack Cave, Tenn.

\section{Ceuthophilos stygius.}

Rhaphidophora stygia Scudd.!, Proc. Bost. Soc. Nat. Hist., viii. 9 (1861); Pack., Amer. Nat., v. 745 (1871).

Ceuthophilus stygius Scudd.!, Bost. Journ. Nat. Hist., vii. 438 (1862) ; Walk., Cat. Derm. Salt. Brit. Mus., i. 202 (1869); Pack., Guide Ins., 565 (1869) ; Riley, Stand. Nat. Hist., ii. 184 (1884); Pack., Mem. Nat. Acad. Sc., iv. 70-71, 83 (1888) ; Brunn., Monogr. Stenop., 65 (1888) ; Blatchl., Proc. Ind. Acad. Sc., 1892, 148-149 (1894).

Ceuthophilus sloanii Pack.!, Ann. Rep. Peab. Acad. Sc., v. 93-94 (1873) ; Id.!, Mem. Nat. Acad. Sc., iv. 71, 83 (1888). Immature.

Body pale brown, the segments bordered posteriorly with dark brown or black, becoming gradually paler toward the hinder part of the body and dotted with pale spots; the markings in general closely resemble those of $C$. gracilipes, but the dark colors do not generally prevail to so great an extent as in that species. The antennx, moderately

voL. $\mathrm{xxx}$. (N. $\mathrm{s} \times \mathrm{x} \times 11$.) 
coarse at the base, taper very gradually, and are of immense length, being more than four times the length of the body. The legs are very long and slender. Fore femora scarcely broader than middle femora, very slender, three fourths as long again as the pronotum, yet only about half as long as the hind femora, the inner carina armed with 2-5 spines. Middle femora with $2-\overline{5}$ spines on the front carina and on the hinder 1-3 spines besides a not very long genicular spine. Hind femora about as long as the body and twice the length of the fore femora, not very stout, about four times as long as broad, tapering gracefully, the apical third being subequal, the darker portions covered with exceedingly fine and subdued raised points, the outer carina with more or less slight distant serrations or triangular denticulations occasionally developing as spines, especially on the apical half, the inner carina with a few slighter distant similar serrations closest in the middle half, the intervening sulcus not very broad. Hind tibiæ slender, straight in both sexes, fully a tenth longer than the femora, armed beneath with 2-3 subapical spines besides the apical pair; spurs vaguely opposite or subopposite, the basal within the proximal fourth of the tibia, about half as long again as the tibial depth, set at an angle of about $40^{\circ}$ with the tibia and divaricating about $90^{\circ}$, their tips much incurved; inner middle calcaria much longer than the outer, more than twice as long as the others or as the spurs and as long as the first joint of the tarsus, beset with short hairs, as are also the upper calcaria. Hind tarsi fully two fifths the length of the tibia, the first joint shorter than the rest combined, the second twice as long as the third and with it shorter than the fourth. Cerci rather long and slender, tapering to a fine point, fully balf as long as the hind femora. Ovipositor three fifths the length of the hind femora, not greatly swollen at base, tapering gently in basal half, equal beyond and not very narrow, the tip scarcely upturned and not produced, the apex being nearly rectangular, the teeth of the inner valves feebly crenate.

Length of body, \& $17 \mathrm{~mm} .$, \& $19.5 \mathrm{~mm}$; pronotum, $\delta 5.5 \mathrm{~mm}$., क $5.3 \mathrm{~mm}$; fore femora, of $\$ 9.75 \mathrm{~mm}$.; hind femora, of $19.5 \mathrm{~mm}$., १ $20.1 \mathrm{~mm}$. ; hind tibiæ, of $21.5 \mathrm{~mm}$., $\% 22.8 \mathrm{~mm}$.; ovipositor, $13 \mathrm{~mm}$.

1 \&, 3 \%. Hickman's Cave, Ky., A. Hyatt ; cave in Crawford Co., Ind., W. P. Hay, through W. S. Blatchley. In the Museum of Comparative Zoölogy there are specimens taken at White's Cave, near Mammoth Cave, Ky.; Fountain's Cave, A. S. Packard; and One Hundred Dome Cave, near Glasgow Junction, Ky., F. G. Sanborn, 
II. Garman. Packard, in his Memoir on Cave Animals, reports it also from Little and Great Wyandotte Caves, a cave in Washington Co., and Georgetown, Floyd Co., all in Indiana, and also from the following caves in Kentucky: Diamond Cave, near Mammoth Cave, John and Fred Field Cave, near Dismal Creek, Bee Spring and Laurel Caves, Carter Co. According to Brunner, specimens seen by him come from Texas. C. sloanii was described from caves in Kentucky aud Bradford, Ind.

\section{Ceuthophilus gracilipes.}

Phalangopsis gracilipes Hald., Proc. Amer. Assoc. Adv. Sc., ii. 346 (1850) ; Walk., Cat. Derm. Salt. Brit. Mus., i. 116 (1869).

Rhaphidophora gracilipes Scudd.!, Proc. Bost. Soc. Nat. Hist., viii. 7 (1861).

Ceuthophilus gracilipes Scudd.!, Bost. Journ. Nat. Hist., vii. 439 (1862) ; Walk., Cat. Derm. Salt. Brit. Mus., i. 202 (1869); Scudd.!, Rep. U. S. Geol. Surv. Nebr., 249 (1872) ; Brunn., Monogr. Stenop., 62-63 (1888) ; Smith, Cat. Ins. N. J., 409 (1890) ; McNeill, Psyche, vi. 27 (1891).

Ground color of body varying from luteous to dark castaneous, very heavily marked with blackish fuscous, so that the latter is often or perhaps generally the prevailing tint; the darker colors prevail always on the hinder half of all the segments but the pronotum and sometimes, especially in young specimens, to such an extent that all parts behind the pronotnm are blackish fuscous, dotted with luteous; in the lightest colored specimens, the dark coloring prevails on the pronotum along the anterior and especially the posterior margins, and is generally present in a subdorsal posterior tongue emitted on either side from the anterior margin; the anterior edge of the dark posterior markings of each segment, especially in the front portion of the body, is exceedingly irregular and broken, and the lightest parts are more or less and irregularly clouded with fuscous; the femora are usually of the prevailing tint of the body, but, even when the body is dark, are sometimes luteous throughout as the tibiæ and tarsi always are, except for occasional infuscation of the former at base; the outer sides of the hind femora have the characteristic markings of the genus more or less distinct. Antennæ moderately coarse at base, tapering with great regularity, 3-4 times the length of the body. Legs very long and slender. Fore femora no stouter than the middle femora, more than half as long again as the pronotum, especially in the $\delta$, distinctly less than half as long as the fore femora, the inner carina usually with 2-3 
spines, often rather long in old individuals, especially the distal ones. Middle femora with 3-4 spines on either carina, the bind carina with a not very long genicular spine. Hind femora as long as or longer than the body, considerably more than twice the length of the fore femora, very stout at base, but gradually diminishing in stoutness so that the distal third is slender and subequal and the whole less than three and a half times longer than broad, the surface mostly glabrous, but on the darker portions above beset not very sparsely with feeble raised points, the outer carina with about thirteen distant unequal rather coarse spines, the longest shorter than the tibial spurs $(\delta)$ or almost unarmed ( $\$$ ), the inner carina much less elevated than the outer, with equal abortive denticulations numerous in the $\delta$, infrequent and equidistant in the $\$$, the intervening sulcus moderately broad. Hind tibiæ rather slender, straight or in old male specimens gently subarcuate or slightly waved in the proximal third, nearly a sixth longer than the femora, armed beneath usually with two aligned preapical spines besides the apical pair; spurs subopposite, the basal pair near end of proximal fourth of tibia, less than half as long again as the tibial depth, set at an angle of about $40^{\circ}$ with the tibia and usually divaricating about $60^{\circ}$, but sometimes to as much as twice that, incurved especially at tip; inner middle calcaria much longer than the outer, more than twice as long as the other calcaria, about twice the length of the spurs, but much shorter than the first tarsal joint. Hind tarsi much less than half as long as the tibia, the first not so long as the rest together, the second nearly three times as long as the third and with it fully as long as the fourth. Cerci stout at base, tapering throughout, nearly a third as long as the hind femora. Ovipositor with the basal third rather.stout, beyond equal and rather slender, nearly three fourths the length of the hind femora, the armature of inner valves acicular, arcuate, elongate.

Length of body, $\delta 19 \mathrm{~mm}$., $\& 23 \mathrm{~mm}$; antennæ, $\delta$ (est.) $75 \mathrm{~mm}$;

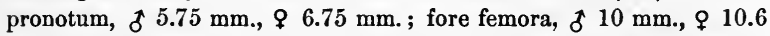
mm.; hind femora, $\delta 21.5 \mathrm{~mm}$., $\& 22 \mathrm{~mm}$; hind tibix, $\delta 24.75 \mathrm{~mm}$., \& $25 \mathrm{~mm}$. ; ovipositor, $15.5 \mathrm{~mm}$.

22 ð, 11 \&. Maryland, New Jersey, P. R. Uhler ; Ithaca, N. Y., Comstock; Blockton, Florida (C. Caule, Jr.), J. H. Comstock; Southern Illinois, P. R. Uhler; Illinois, Walsh, Webster; Northern Illinois, R. Kennicott ; Minnesota ; Red River, Manitoba, D. Gunn; Nebraska City, Nebr., F. V. Hayden. It bas also been reported from Pennsylvania by Haldeman, and from Georgia and Colorado by Brunner. 


\section{Ceuthophilus latebricola, sp. nov.}

Blackish fuscous, sometimes almost piceous, glabrous, profusely spotted with luteous or rufo-luteous and more or less blotched with the same on the thoracic segments, though nowhere in large masses, but, except the luteous bordering of the inferior margins, more as if through the confluence of minute spots. There is al ways a narrow mediodorsal line or stripe on the thoracic segments with slight expansions anteriorly and posteriorly on the pronotum; legs luteous with heavy blackish infuscations at the femoral tips, the hind femora heavily marked with fuscous scalariform markings. The antennæ are slender and about three times as long as the body, and the legs moderately long and slender. Fore femora no stouter than the middle femora, considerably less than half as long as the hind femora, a little more ( $\delta$ ) or a little less (\$) than a third longer than the pronotum, the inner carina with a long preapical spine and sometimes another much smaller. Middle femora with 2-4 spines on the front carina and on the hind carina with 1-2 spines besides a long genicular spine. Hind femora about as long as the body, considerably more than twice as long as the fore femora, moderately stout, in the male somewhat strongly constricted before the genicular lobes, about three and a quarter times longer than broad ( $\delta$ ), the surface with only a few raised points along the upper edge interiorly, the outer carina considerably elevated before the constriction, armed with 6-9 unequal teeth, the largest tumid at base and not so long as the tibial spurs $(\delta)$ or with 2-3 feeble serrations ( $\$$ ), the inner carina with distant feeble minute spinules (\$), the intervening sulcus slender. Hind tibiæ sinuate in the proximal half $(\delta)$ or straight throughout ( $\$$ ), considerably longer than the femora (scarcely longer in Eastern examples), armed beneath with a single subapical spine besides the apical pair; spurs subopposite, the basal just before the end of the proximal third of the tibia, about half as long again as the tibial depth, set at an angle of $45^{\circ}$ with the tibia and divaricating $100^{\circ}$, their apical third incurved; inner middle calcaria very much longer than the outer, almost twice as long as the others or as the spurs and nearly as long as the first joint of the tarsi. Hind tarsi not a third as long as the tibix, the first joint longer than the rest together, the second fully twice as long as the third and with it at least as long as the fourth. Cerci rather stout, rapidly tapering, a little longer than half the femoral width. Abdomen roundly truncate in the male. Ovipositor straight, two thirds as long as the hind femora, gently tapering in basal third, beyond equal and slender, the 
tip considerably upcurved and very acuminate, the teeth of the inner valves aculeate.

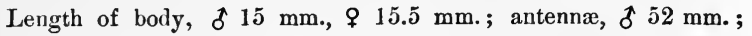
pronotum, of $5 \mathrm{~mm}$., $\$ 4.75 \mathrm{~mm}$; fore femora, of $6.9 \mathrm{~mm}$., $\$ 6 \mathrm{~mm}$; hind femora, of $15.5 \mathrm{~mm}$., $q 13.5 \mathrm{~mm}$; hind tibiæ, of $17.5 \mathrm{~mm}$., ९ $14.5 \mathrm{~mm}$.; ovipositor, $9 \mathrm{~mm}$.

4 8 , 6 \%. Lexington and Tyrone, Ky. (S. Garman); Washington, D. C., Wright; Centre Co., Peun., Shaler ; and Petroleum, Ritchie Co., W. Va. (Mus. Comp. Zoöl.).

\section{Ceuthophilus grandis, sp. nov.}

Body dark luteo-castaneous very heavily marked with blackish or blackish fuscous, which is heaviest at the posterior margins of all the segments, along the front margin of the pronotum, and in a stripe bordering the broad mediodorsal rufo-luteous stripe of the pronotum; the anterior lower angle of the pronotum, and to some extent that of the other thoracic segments, are dull luteous, merging with the luteous of the central portion of the descending lobes; on the abdomen the darker colors prevail above to such a degree that the luteous appears to be maculate on a dark ground; antennæ and legs luteotestaceous, more or less though generally feebly infuscate, the hind femora with fuscous scalariform markings, apically broadly marked with fuscous but preceded by a broad more or less clearly marked luteous annulation. The antennæ are slender except near the base and fully four times as long as the body, the legs very long and slender. Fore femora scarcely stouter than the middle femora, barely half as long as the hind femora, two thirds $(\delta)$ or three fifths $(q)$ as long again as the pronotum, the inner carina with 3-4 spines none of them very long nor very unequal. Middle femora similarly armed on the front carina and on the hind carina 3-4 spines besides the moderately long genicular spine. Hind femora as long as the body, very little more than twice as long as the fore femora, pretty stout at base, but with the slender portion much produced, the apical third or in the female even more than that being subequal, the whole being in the male nearly four and a half times longer than broad, the surface above and on both sides just beyond the middle with a few scattered raised points, the outer carina armed throughout all but extreme base with 8-12 distant, not greatly unequal, subequidistant spines, the longest scarcely so long as the tibial spurs but tumid at base $(\delta)$ or with similarly distant feeble serrulations ( $q$ ), the inner carina sparsely $(\delta)$ or very sparsely (\$) serrulate, the intervening sulcus narrow. Hind 
tibiæ straight in both sexes, fully a tenth longer than the femora, armed beneath with 1-2 subapical spines (one sometimes paired) besides the apical pair; spurs subopposite, the basal at about the end of the proximal third of the tibia, slightly longer than the tibial depth, set at an angle of $50-60^{\circ}$ with the tibia and divaricating about $120^{\circ}$, their tips much incurved; inner middle calcaria very much longer than the outer, fully twice as long as the others or as the spurs and nearly as long as the first joint of the tarsi. Hind tarsi two fifths as long as the tibiæ, the first joint about as long as the rest together, the second nearly three times as long as the third and with it as long as the fourth. Cerci slender and delicately tapering, a quarter as long again as the femoral breadth. Ovipositor more than half as long as the hind tibix, the lower margin straight, not stout and gently tapering in the basal half, slender and equal in the apical half, the tip upturned and bluntly acuminate, the teeth of the inner valves triangular and rather long, straight.

Length of body, $\delta 19 \mathrm{~mm}$., $\$ 23.5 \mathrm{~mm}$; antennæ (est.), ठ $90 \mathrm{~mm}$; pronotum, $\delta$ \& $6.7 \mathrm{~mm}$; fore femora, of $11.25 \mathrm{~mm}$., $\$ 10.75 \mathrm{~mm}$; hind femora, $\delta 22.8 \mathrm{~mm}$., $\$ 23.4 \mathrm{~mm}$; ; hind tibix, $\delta 25 \mathrm{~mm}$., $\$ 25.6$ $\mathrm{mm}$; ovipositor, $13.5 \mathrm{~mm}$.

1 §, 2 \&. Chattanooga, Tenn., J. W. Martin (U. S. Nat. Mus.).

This species is not far removed from $C$. gracilipes in structural details, though with much duller and less diversified markings.

\section{Ceutholinlus secretus, sp. nov.}

In markings this species agrees altogether with $C$. palmeri except that the luteous colors are clearer and that the abdomen is more completely fuscous, the luteous being almost entirely confined to a narrow stripe across the anterior margin, not seen when the segments are contracted. The antennæ are fully three times the length of the body, slender and gradually tapering, the legs long and slender. Fore femora scarcely stouter than middle femora, considerably more than half as long again as the pronotum and about half as long as the hind femora, the inner carina with 1-3 small spines. Middle femora with 2-4 spines of varying length on the front carina, and on the hind carina occasionally a single small spine besides the long genicular spine. Hind femora nearly as long as the body, about twice the length of the fore femora, tapering with no abruptness, nearly four times as long as broad, the apical fourth subequal, with scattered but nowhere numerous minute raised points on the upper apical half, the outer carina with small but rather coarse unequal spines, mostly next the narrower por- 
tion of the femora, the longest less than a third as long as the tibial spurs, the inner carina with similar but smaller and subequal spines throughout its extent, on both far more delicate in the female than in the male, the intervening sulcus decidedly narrow. Hind tibiæ straight in both sexes, slender, about an eighth longer than the $\cdot$ femora, armed beneath with two subapical spines besides the apical pair; spurs scarcely subopposite, the basal at the end of the proximal third of the tibia, almost or quite twice as long as the tibial depth, set at an angle ordinarily of $30-40^{\circ}$, but sometimes of more nearly $80^{\circ}$ with the tibia, divaricating $100-160^{\circ}$, their tips incurved inner middle calcaria considerably longer than the outer, nearly twice as long as the others or as the spurs, but much shorter than the first tarsal joint. Hind tarsi almost half as long as the tibiæ, the first joint as long as the rest together, the second three times as long as the third and with it longer than the fourth. Cerci slender, tapering, half as long again as the femoral breadth. Ovipositor fully three fourths as long as the hind femora, gently and uniformly arcuate throughout, of equal width throughout, the tip not sharply acuminate, the inner valves with a feebly crenulate armature.

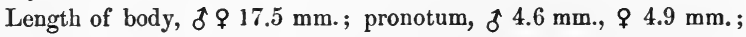
fore femora, of $8 \mathrm{~mm}$., $\$ 7.8 \mathrm{~mm}$; hind femora, of $16 \mathrm{~mm}$., $\$ 14.75$ mm. ; hind tibiæ, of $18 \mathrm{~mm}$., $\& 16.5 \mathrm{~mm}$; ovipositor, $11.6 \mathrm{~mm}$.

6 oे, 2 \%. Dallas, Texas, Boll.

\section{Ceuthophilus palmeri, sp. nov.}

Dark fuscous heavily blotched and spotted with dull luteous, the lighter markings consisting of a broken mediodorsal stripe of generally varying and greater or less width, of very irregular blotches and tortuous streaks on the sides of the pronotum, of large anterior spots on the sides of the meso- and metanotum, and of anterior transverse dashes or belts on the abdominal segments; the fore and middle legs are fusco-luteous becoming more or less deeply fuscous at the distal extremity of the femora and proximal end of the tibix, the hind femora fuscous except at base with the usual dull luteous markings, the rest of the leg dull luteous, but the basal half of the tibiæ more or less infuscated. The antennæ are three or four times as long as the body, and very slender except toward the base, and the legs long and slender. Fore femora no stouter than the middle femora, about three fifths as long again as the pronotum and half or less than half as long as the hind femora, the inner carina with $2-4$ mostly long spiues. Middle femora with 1-2 spines besides a long subapical one on the 
front carina, and on the hind carina 2-3 spines besides a very long genicular spine. Hind femora nearly as long as the body, fully twice as long as the fore femora, stout basally but rapidly tapering so that the apical third or more is subequal, nearly four times as long as broad, with no raised points, both carinæ distantly and finely serrulate in the apical half, a little finer and more distant in the female than in the male, the intervening sulcus not very broad. Hind tibiæ straight in both sexes, fully a sixth longer than the femora, armed beneath usually with two subapical spines besides the apical pair; spurs subalternate, the basal a little beyond the proximal fourth of the tibia, nearly three times as long as the tibial depth, set at an angle of about $50^{\circ}$ with the tibia and divaricating $110-130^{\circ}$, their tips considerably incurved; inner middle calcaria a good deal longer than the outer, fully twice as long as the others or as the spurs, but shorter than the first joint of the tarsi. Hind tarsi more than two fifths the length of the tibix, the first joint as long as the rest together, the second three times as long as the third and as long as the fourth. Cerci very long and slender, but shorter than the fore femora. Ovipositor two thirds as long as the hind femora, very feebly arcuate, rather slender, tapering gently throughout, a little upturned and very acutely pointed at tip, the apical teeth of the inner valves delicate and finely pointed, but not very long, especially the proximal.

Length of body, \& $23 \mathrm{~mm}$., $\$ 19 \mathrm{~mm}$; pronotum, \& $6 \mathrm{~mm}$.; \$ $5.75 \mathrm{~mm}$.; fore femora, $\delta 9.8 \mathrm{~mm}$., $\$ 9 \mathrm{~mm}$; hind femora, $\delta 19.5$ mm., $918 \mathrm{~mm}$.; hind tibiæ, of $23.5 \mathrm{~mm}$., $\$ 21 \mathrm{~mm}$.; ovipositor, $12 \mathrm{~mm}$.

$14 \delta, 14$. From the darkest recesses of the side caverns of a bat cave $48 \times 20$ feet in size, of which the roof had fallen in, in Georgetown, Williamson Co., Texas, E. Palmer; New Braunfels, Texas, H. E. Scudder; Texas, Schaupp in coll. S. Henshaw. The New Braunfels specimen is referred to under $C$. californianus in Bost. Journ. Nat. Hist., vii. 438.

\section{Ceuthophilus corticicola, sp. nov.}

Dark fuscous feebly marked, at least on the pronotum, with cloudy dull luteous vermiculations, especially on the lower part of the descending lobes, which are generally edged more distinctly with luteous; legs of the color of the body or lighter, the anterior pairs more or less infuscated near the femoro-tibial articulation, the distal part of the tibiæ and tarsi more clearly luteous; hind femora with the usual markings, growing luteous toward the base. The antennæ are slender 
and three or more times as long as the body, the legs long and slender. Fore femora faintly stouter than the middle femora, more than half as long again as the pronotum and fully half as long as the hind femora, the inner carina with 2-3 long spines. Middle femora with 2-3 pretty long spines on the inner carina, and on the outer two small ones besides a long genicular spine. Hind femora about as long as the body, nearly twice as long as the fore femora, moderately stont in the basal half, but the swollen portion short, the apical third being subequal and the whole about four times as long as broad, the upper half with a very few scattered raised points apically, the outer carina feebly delicately and distantly serratulate on the distal half, more delicately in the $q$ than in the $\delta$, the inner carina similarly but more closely spined throughout, the intervening sulcus narrow. Hind tibiæ straight in both sexes and slender, nearly a sixth longer than the femora, armed beneath with 1-2 subapical spines besides the apical pair ; spurs subalternate, the basal just beyond the proximal fourth of the tibia, fully twice as long as the tibial depth, set at an angle of about $45^{\circ}$ with the tibia and divaricating $100-120^{\circ}$, their tips incurved; inner middle calcaria distinctly longer than the outer, more than twice as long as the others or as the spurs, and nearly equal to the first tarsal joint. Hind tarsi nearly half as long as the tibiæ, the first joint as long as the rest together, the second three times as long as the third, and nearly equal to the fourth. Cerci very long and slender, beyond the inflated basal portion tapering very gradually, as long as the fore femora. Ovipositor long and straight, fully three quarters as long as the hind femora, the base rather slender and tapering, the distal half or more slender and equal, the extreme tip scarcely upturned but very acute, the inner valves with an armature of fine but not very long pointed teeth.

Length of body, $\delta 17.5 \mathrm{~mm}$., $\$ 19.5 \mathrm{~mm}$; pronotum, $\delta 5.2 \mathrm{~mm}$., \$ $5.75 \mathrm{~mm}$; fore femora, of $8.2 \mathrm{~mm}$., \& $8.75 \mathrm{~mm}$.; hind femora, क $15.75 \mathrm{~mm}$., \& $17 \mathrm{~mm}$; hind tibix, of $18.4 \mathrm{~mm}$., \& $18.75 \mathrm{~mm}$.; ovipositor, $13 \mathrm{~mm}$.

5 f, 2 \%. Dallas, Texas, Boll. Texas, Belfrage, in woods under bark, and coming to the light at night in September.

\section{Ceuthophilus varicator, sp. nov.}

Dull testaceous, heavily infuscated especially on the thoracic segments which are more fuscous than testaceous, the latter appearing on the pronotum principally as an impure fuscous-streaked blotch in the middle of either lateral half, more or less connected posteriorly by 
a transverse bar; a transverse anterior series of four testaceous dots; on the other thoracic segments appearing in large anterior lateral spots more or less confluent; legs fusco-testaceous, becoming luteous apically, the hind femora testaceous with scalariform fuscous markings, the other femora darker apically than at base. The antennæ are tolerably stout at base but soon taper to a delicate thread and are about three times as long as the body, and the legs moderately long and slender. Fore femora no stouter than the middle femora, nearly half as long as the hind femora, and more than a third longer than the pronotum ( $\delta \&$ ), the inner carina armed with 2-3 spines, the subapical very long. Middle femora similarly armed on the front carina, and on the hind carina 1-2 moderate spines besides a very long genicular spine. Hind femora a little more than twice as long as the fore femora, moderately slender, being almost three and three quarters times as long as broad ( $\delta)$, the apical fourth subequal, the surface with no raised points, the outer carina entirely unarmed except for 4-5 very distant slight recumbent serrations on the apical half, more distinct in the $q$ than in the $\delta$, the inner carina with a few raised points, the intervening sulcus narrow. Hind tibiæ straight in both sexes, slender, fully a tenth longer than the femora, armed beneath with two median subapical spines besides the apical pair; spurs subalternate, the basal at or beyond the end of the proximal fourth of the tibia, more than twice as long as the tibial depth, set at an angle of about $80^{\circ}$ with the tibia and divaricating about $150^{\circ}$, their extreme tips incurved; inner middle calcaria very much longer than the outer, about twice as long as the others, or as the spurs, and just about as long as the first tarsal joint. Hind tarsi more than two fifths the length of the tibix, the first joint longer than the rest together, the second three times as long as the third, and as long as the fourth. Cerci slender, tapering, a third as long again as the femoral breadth. Ovipositor two thirds the length of the hind femora, faintly arcuate throughout, equal from close to the base, moderately broad, the tip scarcely upturned, acutangulate (about $40^{\circ}$ ), the inner ralves feebly crenulate, the prominences slightly accentuated.

Length of body, \& $17 \mathrm{~mm}$., \& $20 \mathrm{~mm}$; antennæ (est.), \& $50 \mathrm{~mm}$., $\$ 8 \mathrm{~mm}$.; pronotum, $\delta 5.25 \mathrm{~mm}$., $\& 6.4 \mathrm{~mm}$. ; fore femora, $\delta 7.5$ mm., $\$ 8.9 \mathrm{~mm}$.; hind femora, o $15.75 \mathrm{~mm}$., $\& 18 \mathrm{~mm}$; hind tibiæ, of $18 \mathrm{~mm}$., \& $20 \mathrm{~mm}$. ; ovipositor, $12 \mathrm{~mm}$.

1 \&, 1 \&. Waco, Texas, July 13 (Mus. Comp. Zoöl.). 3 from Columbus, Texas, are in the Riley collection (U. S. National Museum). 


\section{Ceuthophilus latibuli.}

Ceuthophilus latibuli Scudd.!, Ins. Life, vi. 313-314 (1894).

Dark brownish fuscous, heavily blotched with ferrugineo-testaceous, largely in the form of small longitudinally ovate spots more or less regularly disposed on the dorsum, but inclined to become confluent on the sides, and forming blotches on the pronotum, the hind femora dark with two series of longer and an intermediate series of shorter oblique testaceous lines, forming scalariform markings, all the tarsi and at least the distal half of the tibiæ pallid luteous. The antennæ are slender and fully three times as long as the body, and the legs long and slender. Fore femora slightly stouter at base than the middle femora, half as long again as the pronotum, considerably less than half as long as the hind femora, the inner carina armed with 2-4 longer or shorter spines on the distal half. Middle femora with two or three usually long spines besides a subapical long spine on the front carina, and on the hind carina a very long genicular spine, besides sometimes an additional spine. Hind femora about as long as the body, considerably more than twice as long as the fore femora, rather stout, but more than the distal fourth slender and subequal, the whole three $(\delta)$ to three and a half ( $\uparrow)$ times as long as greatest breadth, the surface very finely and uniformly scabrous with delicate raised points on the darker portions, the outer carina slightly prominent, furnished with 8-9 rather unequal inequidistant short spines, the longest not half the length of the tibial spurs $(\delta)$ or unarmed $(\$)$, the inner carina with 13-16 small inequidistant ( $ठ$ ) or 6-8 inconspicuous (\$) spines, the intervening sulcus rather deep but of moderate width. Hind tibiæ much longer than the femora, straight in both sexes, slightly compressed at the base, armed beneath with 1-2 median subapical spines, besides the apical pair; spurs not opposite, the basal generally at or before the end of the proximal fourth of the tibia, nearly or quite three times as long as the tibial depth, set at an angle of about $60^{\circ}$ with the tibia and of about $120^{\circ}$ more or less with each other, slightly incurved at tip; inner middle calcaria very slender, considerably longer than the outer, twice as long as the others or as the spurs and considerably longer than the first tarsal joint. Hind tarsi distinctly less than half as long as the tibiæ, the first joint not nearly so long as the rest combined, the second twice as long as the third and with it shorter than the fourth. Cerci slender, delicately tapering, about as long as the femoral breadth. Ovipositor straight, rather slender, from a third to more than one half as long as the hind tibiæ, the tip hardly upcurved 
and exceedingly acute, the denticulations of the inner valves triangular, hardly aculeate.

Length of body, $\delta 18 \mathrm{~mm}$., $\$ 17 \mathrm{~mm}$; antennæ, $\delta 55+\mathrm{mm}$., \& (est.) $65 \mathrm{~mm}$.; pronotum, of $5 \mathrm{~mm}$., $\$ 6 \mathrm{~mm}$.; fore femora, o 8 mm., $\$ 8.5 \mathrm{~mm}$; hind femora, $\delta$ \& $18 \mathrm{~mm}$; hind tibiæ, $\delta$ \& 19.5 $\mathrm{mm}$; ovipositor, $10 \mathrm{~mm}$.

7 8, 5 \%. Crescent City, Fla., in burrows of the gopher (Gopherus polyphemus), H. G. Hubbard; Georgia, H. K. Morrison.

\section{Ceuthophilus seclusus, $\mathrm{sp}$. nov.}

Glabrous, blackish fuscous, heavily and irregularly marked with luteous becoming rufo-luteous dorsally, the whole surface about equally divided between the fuscous and luteous, but the fuscous prevails dorsally, the luteous laterally; there is an interrupted and irregular broad rufo-luteous mediodorsal band on the thoracic segments, and the inferior margins of at least the pronotum are bordered with luteous, but the other luteous markings are mostly in the form of rather irregularly scattered, more or less irregularly confluent small round spots, often becoming blotches of great irregularity on the thorax; legs dull luteous, the femora infuscated especially apically and the hind femora heavily marked in a scalariform pattern as well as apically annulate with fuscous. The antennæ are slender and apparently about twice as long as the body, and the legs slender and moderately long. Fore femora not stouter than the middle pair, varying greatly in length in the sexes, in the male being only a little less than half as long as the hind femora and more than a third as long again as the pronotum, in the female very much less than half as long as the hind femora, and not a fifth longer than the pronotum, the inner carina with two spines, at least the subapical rather long. Mıddle femora with 2-4 spines on the front carina and on the hind carina 1-2 spines besides a not very long genicular spine. Hind femora about as long as the body, a little more than twice $(\delta)$ or considerably more than two and a half times ( $\$$ ) as long as the fore femora, slender and very gradually tapering, about three and three quarters times as long as broad, the apical fifth subequal, with no raised points upon the surface, the outer carina minutely and inequidistantly spinulate or subserrate, in the female the serrations much subdued, the inner carina similarly but more finely armed in both sexes, the intervening sulcus narrow. Hind tibiæ straight, scarcely longer than the femora, slender, armed beneath with a single preapical spine besides the apical pair; spurs subalternate, the basal about the end of the 
proximal fourth of the tibia, less than twice as long as the tibial depth, set at an angle of $70-80^{\circ}$ with the tibia and divaricating about $90^{\circ}$ (ठ) or $150-170^{\circ}(q)$, their tips incurved; inner middle calcaria distinctly longer than the outer, much more than twice as long as the others or as the spurs and as long as the first tarsal joint. Hind tarsi much less than half as long as the tibiæ, the first joint as long as the rest together, the second more than twice as long as the third and nearly as long as the fourth. Cerci short, being hardly longer than half the femoral breadth. Extremity of the abdomen roundly truncate in the male. Ovipositor straight beneath, the upper margin broadly arcuate, nearly two thirds as long as the hind femora, tapering in basal, equal and slender in distal half, the tip upcurved and finely acuminate, the teeth of the inner valves aculeate, only the last one arcuate.

Length of body, $\delta 12 \mathrm{~mm}$., $\& 16 \mathrm{~mm}$; pronotum, $\delta 3.5 \mathrm{~mm}$., १ $5.25 \mathrm{~mm}$; f fore femora, $\delta 5 \mathrm{~mm}$., $\$ 6.1 \mathrm{~mm}$; hind femora, $\delta 10.9$ mm., $\$ 16 \mathrm{~mm}$; hind tibiæ, $\delta 11 \mathrm{~mm}$., $\$ 16.3 \mathrm{~mm}$; ; ovipositor, $10.5 \mathrm{~mm}$.

3 \&, 7 \&. Dallas and Crawford Cos., Iowa (J. A. Allen); West Point, Nebr (L. Bruner).

\section{Ceuthophilus terrestris, sp. nov.}

Rhaphidophora lapidicola Scudd.!, Proc. Bost. Soc. Nat. Hist., viii. 7 (1861).

Ceuthophilus lapidicolus Scudd.!, Bost. Journ. Nat. Hist., vii. 435 (1862); Walk., Catal. Derm. Salt. Brit. Mus., i. 201 (1869); Glov., Ill. N. A. Entom., Orth., pl. 7, figs. 4, 5 (1872); Prov., Nat. Canad., viii. 75 (1876) ; Ril., Stand. Nat. Hist., ii. 184 (1884); Smith, Cat. Ins. N. J., 409 (1890) ; Osb. ?, Proc. Iowa Acad. Sc., ii. 119 (1892); Blatchl., Proc. Ind. Acad. Sc., 1892, 147-148 (1894).

Phalangopsis lapidicola Bess., Rep. Iowa Agric. Coll., vii. 206 (1877).

Glabrous, mottled with luteous and blackish fuscous, both colors varying in tint in different individuals ; there is often, but not always, a mediodorsal light stripe on the thorax bordered by dark tints, and the lower portions of the sides are always lighter than the rest; the interrening portions of the thorax may be described as fuscous, heavily sprinkled and blotched irregularly with luteous, sometimes one, sometimes the other prevailing; on the abdomen the darker colors prevail and the lighter appear as a tolerably regular and profuse sprinkling of often confluent luteous dots, most abundant on the posterior portions of the segments; the hind femora have the usual markings, and are feebly and narrowly infuscate apically. The antennæ are slender, 
fully twice as long as the body, the legs moderately short. Fore femora not stouter than the middle pair, a third longer than the pronotum and distinctly less than half as long as the hind femora, the inner carina with a long preapical spine sometimes accompanied by a shorter one. Middle femora with 1-2 spines on the front carina besides a preapical spine, and on the hind carina usually two spines besides the genicular spine. Hind femora somewhat shorter than the body, considerably more than twice as long as the fore femora, less than three times as long as broad, the swollen portion pretty stout, hardly more than the distal sixth of equal width, with a few feebly raised points on the upper apical portion of the inner side only, the outer carina delicately uniformly and densely serrate throughout $(\delta)$ or with a few apical obscure serrations ( $q)$, the inner carina similar. Hind tibiæ straight in both sexes, rather stout in the male, scarcely exceeding the femora in length, armed beneath with a preapical spine besides the apical pair; spurs subopposite, the basal beyond the end of the proximal third of the tibia, hardly or no longer than the tibial depth, set at an angle of $45^{\circ}$ with the tibia and divaricating $90-100^{\circ}$, their tips incurved; inner middle calcaria somewhat longer than the outer, twice as long as the others or as the spurs, but not so long as the first tarsal joint. Hind tarsi two fifths the length of the tibiæ, the first joint nearly as long as the rest together, the second twice as long as the third and with it longer than the fourth. Cerci rather slender throughout, tapering, pointed, as long as the femoral breadth. Ovipositor less than three fifths as long as the hind femora, gently tapering in the proximal half, equal and not very slender in the distal half, the tip upturned a little and pointed at an angle of $45^{\circ}$, the teeth of the inner valves sharp but not aculeate.

Length of body, \& $13 \mathrm{~mm}$., \& $15 \mathrm{~mm}$; pronotum, \& $\$ 4 \mathrm{~mm}$; fore femora, क $5.3 \mathrm{~mm}$., \& $5.6 \mathrm{~mm}$; hind femora, of $12.3 \mathrm{~mm}$., क $12.5 \mathrm{~mm}$; hind tibiæ, of $12.5 \mathrm{~mm}$., o $12.75 \mathrm{~mm}$; ovipositor, $7 \mathrm{~mm}$.

11 శ, 5 \&. North Red River, P. R. Uhler; Chateaugay Lake, Adirondack, N. Y., 2,000', F. C. Bowditch ; New Hampshire; Moosehead Lake, Me.; Cambridge and Lowell, Mass., S. Henshaw; Maryland, P. R. Uhler. Specimens in the Museum of Comparative Zoölogy are from Anticosti (Verrill), from Norway (Smith), Bethel (Miss Edwards), and Gorham, Me., and from Nahant and Malden, Mass. (A. Agassiz). It is also reported, partly no doubt by mistake for other species, from Iowa (Bessey, Osborn), Penn., Md., Geo., Ind. (Walker), Canada (Provancher), New Jersey (Smith), Indiana (Blatchley), and Nebraska (Bruner). 


\section{Centhophilus celatus, sp. nov.}

Body blackish fuscous, glabrous, liberally sprinkled with luteotestaceous giving it a speckled appearance in best marked specimens; some of these spots or dots are clustered in a more or less conspicuous mediodorsal stripe, while others margin subequidistantly the posterior border of all the abdominal segments or are submarginal ; on the pronotum and to a less degree on the meso- and metanotum they are liable to coalesce and form vague and irregular patches and blotches; the fore and middle legs are luteous, more or less infuscated especially at the distal ends of the femora; hind femora brownish fuscous, often with an olivaceous tint, the scalariform markings nearly obsolete. Antennæ very slender, about twice the length of the body, the legs rather short. Fore femora no stouter than the middle femora, about a third ( $\delta$ ) or a fourth ( $\$$ ) longer than the pronotum, and much less than half as long as the hind femora, the inner carina with a subapical spine sometimes accompanied by a few others near it. Middle femora with a subapical spine sometimes accompanied by one or two others ou the front carina, and on the hind carina a not very long genicular spine sometimes accompanied by two others. Hind femora rather slender, tapering almost regularly, about three and a half times as long as broad, considerably more than twice as long as the fore femora, with no raised points upon the surface, the outer carina very finely denticulate ( $\delta$ ) or wholly or almost wholly unarmed (\$), the inner carina feebly and very finely serratulate, the intervening sulcus narrow. Hind tibiæ straight in both sexes, a little longer than the femora, slender, armed beneath with a single subapical spine besides the apical pair; spurs opposite or subopposite, the basal at the end of the proximal fourth of the tibia, no longer than the tibial depth, set at an angle of about $45^{\circ}$ with the tibia and divaricating about $60^{\circ}$; inner middle calcaria considerably longer than the outer, more than twice as long as the others or as the spurs, but shorter than the first tarsal joint. Hind tarsi a little less than half as long as the tibia, the first joint scarcely as long as the rest together, the second much more than twice as long as the third and with it longer than the fourth. Cerci slight, tapering regularly, about three fourths as long as the femoral breadth. Ovipositor straight, tapering on the proximal, slender and equal on the distal half, somewhat more than half as long as the hind femora, the tip very gradually attenuated and very slightly upcurved, not very finely pointed, the inner valves rather feebly crenulate.

Length of body, \& $9 \mathrm{~mm}$., \& $13 \mathrm{~mm}$.; pronotum, of $3 \mathrm{~mm}$., $\$ 3.5$ 
mm. ; fore femora, of $4 \mathrm{~mm}$., $\$ 4.25 \mathrm{~mm}$; hind femora, $\delta 9 \mathrm{~mm}$., $\$ 10 \mathrm{~mm}$.; hind tibiæ, $\delta 9.5 \mathrm{~mm}$., $\$ 10.75 \mathrm{~mm}$.; ovipositor, $6 \mathrm{~mm}$. $3 \delta, 5$. Behrens, Shaster County, Cal., San Francisco, Cal., Los Angeles, Cal., Coquillett, all from L. Bruner; and Siskiyou, Placer, and Los Angeles Counties, Cal., mostly from Riley's collection (U. S. Nat. Mus.).

\section{Ceuthophilus brevipes.}

Ceuthophilus brevipes Scudd.!, Bost. Journ. Nat. Hist., vii. 434 (1862); Walk., Cat. Derm. Salt. Brit. Mus., i. 201 (1869); Prov., Nat. Canad., viii. 75 (1876); Fern., Orth. N. Engl., 19 (1888); Blatchl.!, Proc. Ind. Acad. Sc., 1892, 148 (1894).

Dull fuliginous brown, but glabrous, marked with very dull and pale luteous dots, occasionally somewhat confluent; there is sometimes, but rarely, a mediodorsal luteous stripe on the pronotum; the dots are generally a little elongate and margin the segments posteriorly, often turned obliquely inward and when accompanied by other dots in advance these arranged to give an added obliquity to their general course; the pronotum is more or less marmorate with dull luteous; the legs have the general tone of the body and the hind femora the usual markings of the genus, the darker colors generally the more extensive, but the pattern obscured apically so that the distal extremity of the femora, including more than the geniculation, is more or less deeply infuscated. The antennæe are stout at base but immediately become slender and are at least twice as long as the body. The legs are short and rather slender. Fore femora no stouter than the middle femora, a third longer than the pronotum and about half as long as the hind femora, the inner carina with a subapical spine. Middle femora with a subapical spine on the front carina and on the hind carina 1-2 spines, sometimes wanting in the $\&$, besides a fairly long genicular spine. Hind femora moderately stout and plump, regularly tapering, about three and a half times longer than broad, the distal fifth equal, the surface with no raised points, both carinæ sparsely and finely serrate in the $\delta$, almost unarmed in the $\$$, the intervening sulcus of moderate breadth and $\mathbf{V}$-shaped. Hind tibiæ considerably longer than the femora, unusually slender, straight in both sexes, armed beneath with two preapical spines besides the apical pair; spurs subopposite, the basal at the end of the proximal fourth of the tibia, nearly half as long again as the tibial depth, set at an angle of $40-45^{\circ}$ with the tibia and divaricating about $135^{\circ}$, their tips incurred; inner middle calcaria considerably longer than the outer, nearly twice 
as long as the others or as the spurs, but much shorter than the first tarsal joint. Hind tarsi about two fifths the length of the tibia, the first joint shorter than the others together, the second twice as long as the third and with it as long as the fourth. Cerci rather slender, regularly tapering, slightly longer than the femoral breadth. Ovipositor gently tapering on proximal, equal on distal half, rather slender, very slightly arcuate, two thirds the length of the hind femora, the tip acute but not produced, the armature of the inner valves a dull and nearly obsolete serration.

Length of body, \& $14 \mathrm{~mm}$., \& $15.5 \mathrm{~mm}$; pronotum, \& $3.9 \mathrm{~mm}$., \& $4.5 \mathrm{~mm}$; ; fore femora, of $5.5 \mathrm{~mm}$., $\& 6 \mathrm{~mm}$; hind femora, of 11 mm., \& $13 \mathrm{~mm}$; hind tibiæ, of $12 \mathrm{~mm}$., $\& 13.5 \mathrm{~mm}$; ovipositor, $8.4 \mathrm{~mm}$.

3 \&, 3 \&. Grand Menan Isl., Me., A. E. Verrill ; Vigo Co., Ind., October, Blatchley. Specimens are in the Museum of Comparative Zoölogy from St. Johns, N. B.

Provancher gives it from Canada with a query, and it appears, but wrongly, in Bruner's list of the Orthoptera of Nebraska (Publ. Nebr. Acad. Sc., iii. 32, 1893).

\section{Ceuthophiles lapidicola.}

Phalangopsis lapidicola Burm., Handb. d. Ent., ii. 723 (1838).

Locusta (Rhaphidophorus) lapidicola De Haan, Bijdr. Kenn. Orth., 178 (1842).

Body glabrous, blackish above and on upper part of sides, with a very broad dark rufous mediodorsal stripe, narrowing on the abdomen and disappearing in the middle of the same, the black portions sprinkled, especially on the abdomen where it covers all the sides, with rufo-luteous dots or small roundish spots, the lower portion of the sides of the thorax and especially of the pronotum luteous, flecked and clouded to a greater or less degree with fuscous ; antennæ fuscous, very distantly and narrowly annulated with luteous; legs luteous, infuscated more or less - and in this very variable - especially at the distal extremity of the femora, the hind femora almost wholly blackish fuscous externally, flecked, streaked, or stained, especially below, with sordid luteous. The antennæ are very slender and at least three and a half times as long as the body, and the legs slender and pretty long. Fore femora barely stouter in the basal half than the middle femora, somewhat less than half as long as the hind femora, nearly a half ( $\left.\delta^{\prime}\right)$ or almost a third ( $\$$ ) longer than the pronotum, the inner carina with two rather short spines. Middle femora with 2-3 rather short spines on the front 
carina and on the hind carina two very feeble spines besides a moderately long genicular spine. Hind femora about as long as the body, somewhat more than twice as long as the fore femora, rather slender, being fully three and a half times as long as broad, the distal third to fourth subequal, the inner surface above and beyond the middle with three or four distant raised points, both carinæ feebly spinulate in the distal half, the outer more strongly than the inner in the male, the reverse in the female which as a whole is a little more feebly armed, the intervening sulcus rather narrow. Hind tibiæ straight in both sexes, of the same length as the femora, armed beneath with 1-2 subapical spines besides the apical pair; spurs subopposite, the basal before the end of the proximal third of the tibia, with sometimes a supplementary spur still farther toward the base, fully half as long again as the tibial depth, set at an angle of about $70^{\circ}$ with the tibia, and divaricating about $160^{\circ}$, the apical third incurved; inner middle calcaria considerably longer than the outer, fully twice as long as the others or as the spurs and scarcely shorter than the first tarsal joint. Hind tarsi two fifths as long as the tibiæ, the first joint somewhat shorter than the rest combined, the second more than twice as long as the third and with it about as long as the fourth. Cerci rather slender, scarcely shorter than the femoral breadth. Ovipositor a little less than two thirds as long as the hind femora, straight, feebly tapering on the basal third, equal and moderately broad beyond, the tip a little upturned and acuminate (about $35^{\circ}$ ), the teeth not long, aculeate.

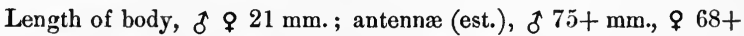
mm. ; pronotum, of $6.5 \mathrm{~mm}$., $\$ 7 \mathrm{~mm}$; fore femora, of $9.5 \mathrm{~mm}$., $\$ 8.9$ mm. ; hind femora and tibiæ, of $20.25 \mathrm{~mm}$., $\$ 20.4 \mathrm{~mm}$. ; ovipositor, $12.75 \mathrm{~mm}$.

$1 \delta, 2 q$, and 3 immature specimens, N. Carolina, Morrison (Coll. Henshaw, Bruner). A $q$ from Pennsylvania is in the Museum of Comparative Zoọlogy, and a $\$$ without locality in the U. S. National Museum.

Burmeister's Phal. lapidicola came from Virginia and South Carolina. The present species is the only one known to me from the Southern Atlantic States which completely or approximately agrees with his description, the species formerly referred by me and others to this being a Northern form to which the description poorly fits, and that described by Brunner under this name is a very different insect. 


\section{Ceuthophilus arizonensis, sp. nov.}

Pallid luteous, so heavily infuscated that behind the pronotum there is only left a single series of luteous spots on each side, which on the meso- and metanotum are transverse oval and rather large, and on the abdomen are transverse anterior stripes, sometimes confluent with those of the opposite side; the pronotum is mostly fuscous, deepest around the margin, more or less dotted and vermiculate with luteous elsewhere, there being commonly a transverse row of dots bordering the anterior fuscous margin, and the disk on either side more or less heavily blotched with the same; the legs are fuscous, varying in depth in different individuals, the hind femora generally with sufficiently conspicuous scalariform markings. The antennæ are very slender and fully three times as long as the body, and the legs are slender but not very long. Fore femora slightly stouter than the middle femora, a third longer than the pronotum and half as long as the hind femora, the inner carina with one or two spines. Middle femora with 1-3 spines on the front carina, and the hind carina generally unarmed except for a slight genicular spine, but sometimes with as many as three other minute spines. Hind femora nearly as long as the body, twice the length of the fore femora, moderately slender, being a little less than three and a half times longer than broad, gradually diminishing in size and yet with the distal fourth subequal, the surface with no raised points, the outer carina with only a few raised points, mostly on the distal half, the inner carina with most minute but sharp distant spinules, the intervening sulcus narrow. Hind tibiæ scarcely longer than the femora, straight in both sexes, very slender, armed beneath with a single preapical spine besides the apical pair; spurs nearly opposite, the basal beyond the end of the proximal third of the tibia, about as long as the tibial depth, set at an angle of from $35-40^{\circ}$ with the tibia and generally divaricating about $70-80^{\circ}$ (one example about $100^{\circ}$ ), their tips incurved; inner middle calcaria a little longer than the outer, fully twice as long as the others or as the spurs, but much shorter than the first tarsal joint. Hind tarsi less than half as long as the tibiæ, the first joint fully as long as the rest combined, the second twice as long as the third and with it as long as the fourth. Cerci stout on the proximal, slender on the distal half, nearly as long as the femoral breadth. Ovipositor four fifths the length of the hind femora, slender, nearly straight, tapering slightly, the tip finely pointed at an angle of about $30^{\circ}$ and barely upturned, the armature of the inner valves aculeate, only the terminal arcuate. 
Length of body, \& $8 \mathrm{~mm}$., \& $11.5 \mathrm{~mm}$.; pronotum, of $2.7 \mathrm{~mm}$, \$ $3.75 \mathrm{~mm}$.; fore femora, of $3.75 \mathrm{~mm}$, $\$ 5 \mathrm{~mm}$.; hind femora, o $7.5 \mathrm{~mm}$., $\$ 10 \mathrm{~mm}$.; hind tibix, \& $8 \mathrm{~mm}$., $\$ 10.2 \mathrm{~mm}$.; ovipositor, $8 \mathrm{~mm}$.

3 đ̊, 9 . St. George, Utah, April 1-12, E. Palmer; Prescott Mt. district, Central Arizona, E. Palmer. One specimen was collected by Xantus, locality not mentioned but not improbably Cape St. Lucas, Lower California. In the U. S. National Museum are $3 \delta, 1 \%$, from Ft. Wingate, N. Mex. (Shufeldt), in the Riley collection.

\section{Ceuthophilus uniformis, sp. nov.}

Ceuthophilus pallidus Scudd.!, Bull. U. S. Geol. Geogr. Surv. Terr., ii. 261 (1876) ; Id. !, Ann. Rep. Geogr. Surv. West 100th Mer., 1876, 279 ; Brun.?, Bull. Washb. Coll., i. 126 (1885), i. 194-195 (1886); Id. ?, Publ. Nebr. Acad. Sc., iii. 32 (1893).

Smoky luteo-testaceous with a slight olivaceous tinge, glabrous, marked more or less deeply with fuscous along the posterior margins of the segments and geuerally along the anterior margin of the pronotum; in this posterior infuscation are indistinct dots of luteous in a transverse series; generally there is also a mediodorsal luteous line over all the segments but deepest and broadest on the pronotum, which is also laterally irregularly streaked, clouded, or blotched with luteous; beyond the lighter more luteous bases of the femora, the legs are of the body color, but the hind femora are considerably infuscated in a scalariform pattern, apically confluent. The antennæ are slender and nearly or quite three times the length of the body and the legs are moderately short. Fore femora no stouter than the middle femora, more than a third $(\delta)$ or less than a fourth (\$) longer than the pronotum and somewhat less than half as long as the hind femora, the inner carina armed only with a subapical spine. Middle femora with two spines on the front carina, and on the hind carina 2-3 (\$) or 3-4 ( $\delta)$ spines besides a not very long genicular spine. Hind femora nearly as long as ( $\delta$ ) or much shorter than ( $\$$ ) the body, a little more than twice as long as the fore femora especially in the $\$$, pretty stout, in the $\delta$ being but a little more than two and a half times longer than broad, though in the $q$ fully three and a quarter times as long as broad, with no raised points on the surface, or at most four or five scattered insignificant ones on the inner surface in the $\delta$, the outer carina with a few spinous points on the distal half, the inner carina similarly armed but in the $\delta$ weaker, the intervening sulcus narrow. Hind tibix scarcely or no longer than the femora, straight 
in both sexes, slender, armed beneath with a single subapical spine besides the apical pair; spurs almost opposite, the basal rather beyond the end of the proximal third of the tibia, scarcely longer $(\delta)$ or a little longer ( $\%$ ) than the tibial depth, set at an angle of about $45^{\circ}$ with the tibia and divaricating $70-90^{\circ}$, their tips incurved; inner middle calcaria distinctly longer than the outer, twice as long as the others or as the spurs, but distinctly shorter than the first tarsal joint. Hind tarsi nearly half as long as the tibiæ, the first joint fully ( $\delta$ ) or nearly (\&) as long as the rest taken together, the second more than twice as long as the third and nearly as long as the fourth. Cerci rather stout tapering from before the middle, shorter than the femoral breadth. Ovipositor nearly twice as long as the fore femora and not very much shorter than the hind tibiæ, beyond the extreme rery slightly swollen base slender and subequal but gently tapering, slightly arcuate in the distal half, the extreme tip produced to a very fine scarcely upturned point, the armature including the apical members consisting of sharp minute reversed serrations hardly apparent until mature.

Length of body, $\delta 10.7 \mathrm{~mm}$., $\$ 16 \mathrm{~mm}$; pronotum, $\delta 3.25 \mathrm{~mm}$, \$ $4.1 \mathrm{~mm}$; fore femora, of $5 \mathrm{~mm}$., $\& 4.9 \mathrm{~mm}$; hind femora, ठ $10.2 \mathrm{~mm}$., $\& 11 \mathrm{~mm}$; hind tibiæ, o $10.5 \mathrm{~mm}$., $\& 11 \mathrm{~mm}$.; ovipositor, $9.4 \mathrm{~mm}$.

5 §, 9 \%. Plains of Northern New Mexico, eastern slope, October 14 ; Beaver Brook, Col., 6,000', July 11, S. H. Scudder; Empire City, Col., E. Palmer. It has also been reported from Southern Colorado, Manitou and Idaho, Col. (Scudder), Western Nebraska, and Topeka and Berks Co., Kans. (Bruner).

\section{Ceuthophilus heros, sp. nov.}

Body castaneous, so heavily marked with black or blackish fuscous as to appear rather as black marked with castaneous; the latter appears on the pronotum only in a very broad mediodorsal stripe of unequal width, an impure blotch in the middle of the sides usually connected with the former, and an inferior edging sometimes expanding anteriorly ; in younger specimens, however, it extends over nearly all the surface; on the meso- and metanotum it margins the segments anteriorly except below, separated from the black irregularly, and extends mediodorsally across the segments ; on the abdomen it appears as small spots dotting the surface and merging along the anterior margins; the antennæ are pale fuscous obscurely and distantly annulated with luteous; the legs are castaneous, more or less infuscated, the 
hind femora externally marked heavily with fuscous in a scalariform pattern, with a broad obscure castaneous annulation well before the genicular lobes. The antennæ are slender and exceedingly long, about four times as long as the body, and the legs are very long though only moderately slender. Fore femora no stouter than the middle femora, a little less than half as long as the hind femora, and rather more $(\delta)$ or rather less $(\$)$ than three fourths as long again as the pronotum, the inner carina with 2-3 spines. Middle femora with similar spines on the front carina and on the hind carina a couple of similar spines besides a not very long genicular spine. Hind femora fully as long as the body, a little more than twice as long as the fore femora, the basal portion stout and swollen but delicately tapering so that nearly or in the female quite the apical third is subequal, and the whole is four times as long as broad, the upper edge of the inner surface with 4-5 distant raised points, the outer carina with about ten sub-equal spines, the longest much shorter than the tibial spurs $(\delta)$, or with about six slight and distant recumbent spines ( $q$ ), the inner carina rather bluntly denticulate, distantly in the outer half $(\delta)$ or like the outer carina but more closely denticulate ( $\$)$, the intervening sulcus narrow. Hind tibiæ barely arcuate at base ( $\delta$ ) or straight $(\$)$, a very little longer than the femora, armed beneath with 1-2 subapical spines besides the apical pair; spurs subopposite, the basal at the end of the proximal third of the tibia, a little longer than the tibial depth, set at an angle of about $60^{\circ}$ with the tibia and divaricating about $130^{\circ}(\Im)$ or $150-170^{\circ}(\$)$, incurved at tip ; inner middle calcaria a little longer than the outer, twice as long as the others or as the spurs, and as long as the first tarsal joint. Hind tarsi two fifths as long as the tibix, the first joint much shorter than the rest together, the second nearly three times as long as the third and with it fully as long as the fourth. Cerci slender, nearly half as long again as the femoral breadth. Ovipositor three fifths as long as the hind femora, straight, tapering and not very stout in the basal, slender and equal in the apical half, the apex obliquely truncate, upturned, and acuminate but not much produced, the teeth of the inner valves rather short and aculeate.

Length of body, $\delta 23.5 \mathrm{~mm}$, \& $21 \mathrm{~mm}$; antennæ, $\delta 85 \mathrm{~mm}$., $992 \mathrm{~mm}$; pronotum, of $6.25 \mathrm{~mm}$., $\$ 7.2 \mathrm{~mm}$; f fore femora, of 11.5 mm., $\$ 12 \mathrm{~mm}$; hind femora, of $24 \mathrm{~mm}$., $\$ 25 \mathrm{~mm}$.; hind tibiæ, of $25.5 \mathrm{~mm}$., $\& 26 \mathrm{~mm}$; ; ovipositor, $15 \mathrm{~mm}$.

3 ठ, 2 \&. North Carolina, H. K. Morrison; over two hundred were found in one old hollow tree when it was felled. $2 \delta$ and $2 \%$. 
of what is apparently the same species," but smaller, are in the U. S. National Museum from Washington, D. C.

\section{Ceuthophilus uhleri.}

Ceuthophilus uhleri Scudd.!, Bost. Journ. Nat. Hist., vii. 435 (1862); Walk., Catal. Derm. Salt. Brit. Mus., i. 201 (1869) ; Glov., Ill. N. A. Ent., Orth., pl. 8, fig. 8 (1872) ; Riley, Stand. Nat. Hist., ii. 184 (1884); Brunn., Monogr. Stenop., 64-65, fig. 33b (1888); Smith, Catal. Ins. N. J., 409 (1890).

Ceuthophilus latisulcus Blachl.!, Proc. Ind. Acad. Sc., 1892, 146 (1894).

Dull luteo- or rufo-testaceous, very heavily flecked with dark fuscous so as to produce a tolerably uniform mottled appearance, ordinarily a little more open than elsewhere in a narrow mediodorsal streak on the pronotum, and in the tolerably clear luteous or pallid luteous of the inferior margin of the descending thoracic lobes; the flecking is made up of small more or less confluent dots, which assume a certain longitudinal regularity on the abdomen only; legs varying from luteous to testaceous, more or less infuscated, especially on the apical portions of the femora and in the distinct and heavy scalariform markings of the hind femora. The antennæ are moderately stout in the basal, but in the apical half very slender, apparently only a little more than twice the length of the body, the legs moderately long. Fore femora no stouter than the hind femora, much less than half as long as the hind femora, but considerably more than a third longer than the pronotum in the $\delta$ though only a fourth longer in the $q$, the inner carina with $2-3$ spines, the subapical not much longer than the others. Middle femora with the front carina as in the fore femora, the hind carina armed with 1-3 spines besides a moderately long genicular spine. Hind femora longer ( $\delta$ ) or shorter ( $\$$ ) than the body, considerably more than twice as long as the fore femora (at least a third more in the male), stout, the apical third or fourth subequal, about three and a third times as long as broad in the male, the darker portions of the surface of the apical half of the femora and the upper portion of the inner side rather heavily $(\delta)$ or very sparsely (\$) scabrous with raised points, the outer carina armed with 7-8 unequal inequidistant coarse irregular arcuate spines, the largest (just beyond the middle) as long as but much stouter than the tibial spurs $(\delta)$ or almost entirely unarmed but for some 3-4 raised points ( $\$$ ), the inner carina with about sixteen small inequidistant coarse spinules covering the whole length $(\delta)$ or a few slight ones only on the apical fourth of the femora ( $\$$ ), the interven- 
ing sulcus exceptionally broad. IIind tibiæ faintly and irregularly sinuous $(\delta)$ or straight $(\$)$, distinctly longer than the femora, slender, armed beneath with 1-2 subapical spines besides the apical pair; spurs subopposite, the basal at or a little beyond the end of the proximal fourth of the tibia, a little longer than the tibial depth, set at an angle of about $35^{\circ}$ with the tibia and divaricating $80^{\circ}-90^{\circ}$, the apical half incurved; inner middle calcaria much longer than the outer, more than twice as long as the others or as the spurs, but scarcely so long as the first tarsal joint. Hind tarsi two fifths as long as the tibix, the first joint about as long as the rest together, the second nearly three times as long as the third and with it fully as long as the fourth. Cerci rather stout, shorter than the femoral breadth. Ovipositor only slightly enlarged at base, the distal two thirds equal but not very slender, straight, almost two thirds as long as the hind femora, the tip considerably upcurved and finely acuminate, the teeth of the inner valves triangular, increasing in length apically, ouly the terminal arcuate.

Length of body, $\delta$ \& $15.5 \mathrm{~mm}$; antennæ, $\$ 32+\mathrm{mm}$.; pronotum, of $5.1 \mathrm{~mm}$., $\& 4.6 \mathrm{~mm}$.; fore femora, of $7.35 \mathrm{~mm}$., \& $5.75 \mathrm{~mm}$.; hind femora, of $17.75 \mathrm{~mm}$., $\& 13 \mathrm{~mm}$; hind tibix, of $18.5 \mathrm{~mm}$., \$ $14 \mathrm{~mm}$; ovipositor, $8.25 \mathrm{~mm}$.

$7 \delta, 3 \%$. Maryland (P. R. Uhler); Middle States (R. Osten Sacken); Vigo Co., Ind., (W. S. Blatchley); Georgia. It is also reported from New Jersey (Smith) and Tennessee (Brunner). Bruner quotes it doubtfully among Nebraska Orthoptera, but I do not know to what species he refers.

Easily confounded with $C$. blatchleyi.

\section{Ceuthophilus biatchleyi.}

Ceuthophilus uhleri Blatchl.!, Proc. Ind. Acad. Sc., 1892, 144-145 (1894).

In color and markings this species is indistinguishable from $C$. uhleri. The legs and especially the hind femora are slenderer. Fore femora no stouter than the hind femora, much less than half as long as the fore femora, fully a third ( $\delta$ ) or scarcely a fourth ( $\$$ ) as long again as the pronotum, the inner carina with 2-3 spines, the subapical long. Middle femora armed on the front carina much as in the fore legs, the hind carina with a long genicular spine sometimes accompanied by 1-3 other spines, often minute. Hind femora nearly two and a half times as long as the fore femora, longer than the body in both sexes, slendier and tapering, nearly the apical third subequal, three and a half times 
as long as broad in the male and fully three and three quarters in the female, the upper portion of the apical half of the inner surface and to a less degree the upper surface near it with numerous raised points, but not so pronounced as in $C$. uhleri, the outer carina armed exactly as there but with wider intervals between the larger spines and the spines less stout $(\delta)$, or with 2-3 scarcely noticeable spinules near the apex ( $\$$ ), the inner carina with about 12-14 serrulations unequally placed, slight, less numerous and distinctly slighter in the female than in the male, the intervening sulcus only moderately broad. Hind tibiæ with a hardly noticeable arcuation or sinuation in the male, hardly $(\delta)$ or much (\$) longer than the femora, slender, armed beneath with two median subapical spines besides the apical pair; spurs subalternate, the basal at about the end of the proximal fourth of the tibia, considerably longer than the tibial depth, set at an angle of about $35^{\circ}$ with tho tibia and divaricating $98^{\circ}-100^{\circ}$, their apical fourth incurved; inner middle calcaria considerably longer than the outer, more than twice as long as the others or as the spurs, and fully as long as the first tarsal joint. Hind tarsi about two fifths as long as the tibiæ, the first joint longer than the other joints together, the second much more than twice as long as the third and with it longer than the fourth. Cerci stout at base, beyond slender, about as long as the femoral breadth. Ovipositor straight, almost two thirds as long as the hiud femora, very little enlarged at base, tapering almost throughout but very gently, the tip upturned a little and finely acuminate, the armature as in C. uhleri.

Length of body, \& $13.5 \mathrm{~mm}$., $\$ 13 \mathrm{~mm}$; pronotum, $\delta 4.7 \mathrm{~mm}$, \$ $4.5 \mathrm{~mm}$; ; fore femora, $\delta 6.4 \mathrm{~mm}$., $\$ 5.5 \mathrm{~mm}$; hind femora, $\delta 15.75$ mm., $\$ 13.5 \mathrm{~mm}$; hind tibiæ, of $\$ 16.25 \mathrm{~mm}$; ovipositor, $8.5 \mathrm{~mm}$.

2 §, 2 \%. Vigo Co., Indiana (W. S. Blatchley); also from New York, Riley (U. S. Nat. Mus.).

Distinguishable from $C$. uhleri by the slightly different and weaker armature of the carinæ of the hind femora, but especially by the slenderer hind femora, and the narrower inferior sulcus of the same. I probably led Mr. Blatchley into his pardonable error by determining this for him as $C$. uhleri.

\section{Cedthophilus spinosus.}

Ceuthophilus lapidicola Brunn., Monogr. Stenop., 63-64 (1888).

Body dark fusco-castaneous, glabrous, with irregular luteous spots and blotches covering a considerable portion of the thoracic segments; the lower edges of the sides of the thoracic segments are sordid luteous 
and the abdomen is mostly marked with alternate longitudinal bars of luteous and fuscous, the latter prevailing dorsally; legs luteo-castaneous, the hind femora distinctly but not heavily marked with fuscous in scalariform patterns. Legs not very long. Fore femora broader basally than the middle femora, much less than half as long as the fore femora, and only a fifth longer than the pronotum, the inner carina with a short spine besides a long preapical spine. Middle femora armed with three spines on the front carina, the preapical very long, the hind carina with only a couple of very short spines besides the long genicular spine. Hind femora longer than the body, two and a half times as long as the fore femora, very stout but with the distal portion so produced that the apical fourth is equal, the whole three times as long as broad, the surface covered everywhere on the darker portions, but especially on the stouter part of the femora beyond the middle and within as well as without, with raised points closely crowded, the outer carina elevated, armed in the middle third with a series of about five spines, sometimes inequidistant, distally increasing in length, the last and to some extent the others bent-arcuate, about as long as the tibial spurs but coarser, followed by a rapid narrowing of the femora and on this narrow portion by 4-5 minute serrulations, the inner carina pretty regularly and minutely but not closely spinulate, the intervening sulcus broad. Hind tibiæ feebly arcuate, somewhat longer than the femora, armed beneath with a single subapical spine besides the apical pair ; spurs subopposite, the basal at the end of the proximal fourth of the tibia, half as long again as the tibial depth, set at an angle of about $45^{\circ}$ with the tibia and divaricating $90-100^{\circ}$, their tips incurved; inner middle calcaria considerably longer than the outer, fully twice as long as the others or as the spurs, and as long as the first tarsal joint. Hind tarsi about two fifths as long as the tibiæ, the first joint hardly as long as the rest together, the second twice as long as the third, but with it scarcely as long as the fourth. Cerci moderately slender, rather short, probably little exceeding in length the femoral breadth.

Length of body, $13 \mathrm{~mm}$; pronotum, $5 \mathrm{~mm}$. ; fore femora, $6 \mathrm{~mm}$; hind femora, $15 \mathrm{~mm}$; hind tibiæ, $16 \mathrm{~mm}$.

1 ठ.. Georgia.

This species is very closely related to $C$. uhleri, differing in its markings, which are less sprinkled, and in the more pronounced spinulations of the hind femoral carinæ in the male. 


\section{Ceuthofhilus celeus, sp. nov.}

Body glabrous, blackish fuscous above, pallid and more or less sordid luteous on the lower portion of the sides, with a mediodorsal rufo-luteous line and dotted above faintly and rather sparsely with rufo-luteous, some of the dots broadening the mediodorsal line, others next the luteous sides becoming larger and sometimes more distinctly luteous, and on the abdomen often becoming oblique dashes; the very edge of the inferior margins of the thoracic lobes castaneous; antennæ fusco-luteous; legs luteous, more or less infuscated, the hind.femora luteo-castaneous, with heavy and distinct blackish fuscous scalariform markings, much heavier on distal than proximal half. The antennæ are slender and about three times the length of the body, the legs moderately short. Fore femora slightly broader than the middle femora, very much less than half as long as the hind femora and at most $(\delta)$ only a fourth longer than the pronotum, the inner carina with 2-3 spines, at least the preapical long. Middle femora with 2-4 long spines, the preapical very long, on the front carina, the hind carina with 0-2 short spines besides a very long genicular spine. Hind femora as long as the body, two and a half times as long as the fore femora, very stout, scarcely more than three times as long as broad, the stout portion rapidly tapering so that the apical fourth is subequal, the inner surface of the male with a cluster of raised points beyond the middle, above, the outer carina elevated, having on the middle third a row of increasingly larger spinules, the largest still very much shorter than the tibial spurs, followed distally by half a dozen minute and equal spinules $(\delta)$ or unarmed $(q)$, the inner carina with a few small subequal spinules in the distal half, smaller and sparser in the $q$ than in the $\delta$, the intervening sulcus broad. Hind tibiæ straight in both sexes, a little longer than the femora, armed beneath with a single preapical spine besides the apical pair; spurs subopposite, the basal not much beyond the end of the proximal fourth of the tibia, almost twice as long as the tibial depth, set at an angle of $35-45^{\circ}$ with the tibia, divaricating about $130^{\circ}$ at least in the $\$$, their tips considerably incurved ; inner middle calcaria considerably longer than the outer, nearly twice as long as the others or as the spurs, and about as long as the first tarsal joint. Hind tarsi nearly two fifths as long as the tibix, the first joint fully as long as the rest together, the second three times as long as the third and with it fully as long as the fourth. Cerci moderately slender, bluntly pointed, much shorter than the femoral breadth. Ovipositor scarcely longer than the 
fore femora, feebly arcuate, the base moderately stout, the distal three fifths equal and moderately slender, the tip considerably upturned and very acuminate.

Length of body, \& $11.5 \mathrm{~mm} .$, \& $10 \mathrm{~mm}$; antennæ (est.), \& 32 mm., $\uparrow 31 \mathrm{~mm}$.; pronotum, के $4 \mathrm{~mm}$., $\$ 4.25 \mathrm{~mm}$.; fore femora, of $5 \mathrm{~mm}$., ${ }^{2} 4.5 \mathrm{~mm}$.; hind femora, of $12.5 \mathrm{~mm}$., $\$ 11.25 \mathrm{~mm}$; hind tibiæ, के $13.5 \mathrm{~mm}$., $\& 11.7 \mathrm{~mm}$; ovipositor, $4.75 \mathrm{~mm}$.

1 f, 2 \%. Lexington, Ky., June 28, S. Garman. A single imperfect $\delta$ in the National Museum without locality (Missouri?) probably belongs to this species.

\section{Ceuthophilus nigricans, sp. nov.}

Body glabrous, blackish fuscous with obscure rufo-luteous markings, becoming pallid luteous and more distinct on the abdomen; they consist almost wholly of a sprinkling of small roundish spots and dots, more profuse and elongated on the abdomen, but there is besides a very obscure mediodorsal line or stripe on the pronotum; excepting on the under surface of the femora, the femora and tibix are dark fuliginous and the outer side of the hind femora very dark castaneous, heavily infuscated in the apical half, blackish at tip, and with deep and heavy fuscous scalariform markings. The antennæ are slender and at least in the basal portion blackish fuscous, and the legs are rather short, though the hind legs are relatively much longer in the female than in the male. Fore femora not stouter than the middle femora, much less than half as long as the hind femora, particularly in the female, and very little longer than the pronotum, the inner carina with one or two short spines. Middle femora similarly armed on the front carina, the hind carina with one or two spines besides a short genicular spine. Hind femora shorter $(\delta)$ or longer $(q)$ than the body, somewhat more than twice $(\delta)$ or about three times $(q)$ as long as the fore femora, in the male stout and tapering pretty regularly to the genicular lobes, about two and three quarters times longer than broad, the middle of the distal half of the inner surface above with a small cluster of raised points, in the female much slenderer and with the apical fourth subequal, the outer carina uniformly elevated, delicately serratulo-spinous through most of its extent $(\delta)$, or with a few distant spinules in the outer half ( $\$)$, the inner carina armed as the outer but somewhat more delicately $(\delta)$ or with a few raised points (q), the intervening sulcus moderate. Hind tibiæ somewhat longer than the femora, straight in both sexes, armed beneath with a single subapical spine besides the apical pair; spurs subopposite, the basal 
scarcely beyond the end of the proximal fourth of the tibia, about as long as the tibial depth, set at an angle of about $50^{\circ}$ with the tibia and divaricating about $90^{\circ}$, faintly incurved; inner middle calcaria much longer than the outer, nearly twice as long as the others or as the spurs, but much shorter than the first joint of the' tarsus. Hind tarsi not much less than half as long as the tibiæ, the first joint almost as long as the rest together, the second twice as long as the third and with it as long as the fourth. Cerci very short and not very slender. Ovipositor about a fifth longer than the fore femora, straight, not stout and delicately tapering in basal half, the tip upturned and very acuminate, the teeth of the inner valves aculeate, straight.

Length of body, \& $\$ 11.5 \mathrm{~mm}$; pronotum, \& $4.5 \mathrm{~mm}$., $\& 4.35$ $\mathrm{mm}$; fore femora, of $4.75 \mathrm{~mm}$., \& $4.5 \mathrm{~mm}$; hind femora, $\delta 10.75$ mm., $913.4 \mathrm{~mm}$; hind tibiæ, of $11.1 \mathrm{~mm}$. , $\& 14.5 \mathrm{~mm}$; ovipositor, $5.3 \mathrm{~mm}$.

1 ช, 1 \&. Tyrone, Ky., April 23 (S. Garman).

The single $q$ has but one hind leg, and this has been attached after breaking off. As the leg seems to be abnormally different from that of the $\delta$, it is quite possible that it does not belong to this specimen, and that the characters given above drawn from it should be eliminated.

\section{Cedthophilus fosiformis, sp. nov.}

Body testaceous almost wholly overlaid with black above, the abdomen wholly, the meso- and metanotum all but an anterior mesial spot, and the pronotum to such a degree that the testaceous is confined to a large equilateral triangular patch on each side, the inferior margins for their base and a couple of small mesial patches, the larger behind; the lower half of the sides throughout, however, is pallid testaceous; the legs are testaceous and uniform except for rather faint fuscous scalariform markings on the hind femora. The antennæ are slender and about three times as long as the very compact body, and the legs short and not very slender. Fore femora distinctly stouter than the middle femora, somewhat less than half as long as the hind femora and but little longer than the pronotum, the inner carina armed only with a strong subapical spine. Middle femora armed with 2-3 spines on the front carina, the distal scarcely or no longer than the others, and on the hind carina $2-3$ spines besides a moderate genicular spine. Hind femora as long as the body, a little more than twice as long as the fore femora, very stout, the subequal apical portion not over one seventh of the whole, which is three times as long as 
broad only, a few scattered raised points beyond the middle above, the outer carina uniformly and rather closely serrulate, the inner carina similarly but more delicately armed with a tendency to a biseriate arrangement, the intervening sulcus rather broad. Hind tibiæ straight, shorter than the femora, armed beneath with a single subapical spine besides the apical pair; spurs subopposite, the basal at the end of the proximal fourth of the tibia, nearly half as long again as the tibial depth, set at an angle of about $55^{\circ}$ with the tibia and divaricating about $100^{\circ}$, their extreme tips incurved; inner middle calcaria barely longer than the outer, half as long again as the others or as the spurs, and a little shorter than the first tarsal joint. Hind tarsi alnost half as long as the tibix, the first joint about as long as the rest together, the second fully twice as long as the third and with it as long as the fourth. Cerci modèrately slender, considerably shorter than the femoral breadth.

Length of body, $10.5 \mathrm{~mm}$; antennæ, (est.) $28+\mathrm{mm}$.; pronotum, $4.25 \mathrm{~mm}$. ; fore femora, $4.75 \mathrm{~mm}$; hind femora, $10.3 \mathrm{~mm}$.; hind tibiæ, $9.75 \mathrm{~mm}$.

1 §. Lincoln, Nebraska, L. Bruner.

\section{Ceethophilus sallei, sp. nov.}

Dark mahogany brown, glabrous, marked with reddish luteous in a more regular pattern than common, there being a moderately broad mesial stripe of the brighter color, broader on the anterior than the posterior part of the segments, the sides with regularly disposed flecks and dots of luteous, becoming more numerous below, so that the luteous prevails on the lower portion of the sides; on the abdomen the luteous spots are usually either circular or made of short oblique dashes; the legs are as dark as the upper surface, the hind femora with the usual pattern, but the lighter portions subdued in tint. The legs are rather short, the antennæ not stout. Fore femora stouter than the middle femora, especially on the proximal half, about a fifth longer than the pronotum, at least in the $\delta$, very much less than half as long as the hind femora, the inner carina with a couple of spines, the subapical long. Middle femora with two spines besides a long subapical spine on the front carina, and on the hind carina 0-2 spines besides the long genicular spine. Hind femora fully as long as the body, nearly two and a half times longer than the fore femora, very stout, tapering so that the distal fourth is subequal, nearly three times as long as broad, the inner surface scabrous with a cluster of raised points near the middle above, the outer carina with 8-10 distant uuequal serrations or 
spines, one before the middle of the distal half longer than the others and nearly as long as the tibial spurs, stout at base only ( $\delta)$ or minutely and distantly denticulate in the distal half (q), the inner carina with a similar number of small subequal and subequidistant spines ( $\delta)$, or as in the male ( $q)$, the intervening sulcus narrow and deep. Hind tibiæ slender and straight in both sexes, scarcely longer than the femora, armed beneath with a single preapical spine besides the apical pair ; spurs generally opposite, the basal at about the end of the proximal third of the tibia, fully half as long again as the tibial depth, set at an angle of about $50^{\circ}$ with the tibia and divaricating about $140^{\circ}$ with each other, their tips incurved; inner middle calcaria very much longer than the outer, more than twice as long as the others or as the spurs and fully as long as the first tarsal joint. Hind tarsi almost balf as long as the tibix, the first joint nearly as long as the rest together, the second more than twice the length of the third and with it not so long as the fourth. Cerci tapering throughout equally, a little shorter than the femoral breadth, the tip not very pointed. Ovipositor tapering gently in proximal, equal in distal half, the tip upcurved and produced to a fine point, as long as the fore femora, the teeth and apical hook of inner valves slender, long, and arcuate.

Length of body, \& $16 \mathrm{~mm}$., $\$ 14.5 \mathrm{~mm}$; pronotum, \& $5.7 \mathrm{~mm}$., १ $5.5 \mathrm{~mm}$. ; fore femora, of $6.9 \mathrm{~mm}$., $\& 6 \mathrm{~mm}$; hind femora, of 17.5 mm., $\$ 14.8 \mathrm{~mm}$; hiud tibiæ, of $18 \mathrm{~mm}$., $\$ 15 \mathrm{~mm}$; ovipositor, $6 \mathrm{~mm}$.

1 d, 7 \%. New Orleans, Auguste Sallé.

The species is noticeable for the length of all the spines.

\section{Ceuthophilus latens.}

Ceuthophilus latens Scudd., Bost. Journ. Nat. Hist., vii. 437 (1862); Walk., Catal. Derm. Salt. Brit. Mus., i. 202 (1869); Brun., Publ. Nebr. Acad. Sc., iii. 31 (1893) ; Blatchl.!, Proc. Ind. Acad. Sc., 1892, 143-144 (1894).

Body glabrous, with a broad mediodorsal stripe of dark rufo-luteous on the thoracic segments, bordered very broadly on either side with blackish or blackish fuscous, fading out inferiorly, the lower portion of the sides pallid luteous, more or less impure, the very margin luteotestaceous; the abdominal segments obscurely continue these longitudinal markings, but the black becomes brownish fuscous and is so dotted with dull luteous as to give a very different appearance, the segments being marked with alternate and frequent short longitudinal 
or obliquely longitudinal bars of brownish fuscous and dull luteous, the darker parts often also dotted with luteous; legs luteous, more or less infuscated, especially the hind femora the outer surface of which excepting at base is increasingly fuscous distally and broadly annulate with blackish apically, the surface generally sprinkled with luteous dots, with faintly different depths of color marking a scalariform pattern. The hind tibial spines are distinctly blackish at the base. The antennæ are about three times as long as the body, luteous, the joints at first feebly infuscated at the base, afterwards wholly, and then interrupted by luteous for a single joint every few joints irregularly, the legs moderately slender and not very long, the hiud tibial spurs distinctly infuscated or blackish at base. Fore femora slightly stouter than the middle femora, considerably less than half as long as the hind femora, nearly a third longer than the pronotum in the $\delta$, though but little longer in the $\mathcal{q}$, the inner carina armed with 2-3 spines. Middle femora with generally 2-3 spines on the front carina and on the hind carina 1-2 spines besides a moderate genicular spine. Hind femora about as long as the body, at least two and a quarter times longer than the fore femora, the swollen portion very gradually tapering and of unusual length, the whole about three and a quarter $(\delta)$ or three and three quarters ( $($ ) times as long as broad, the surface with no raised points, both outer and inner carina in both sexes almost unarmed, at most a few feeble spinules being seen near the apex, the intervening sulcus narrow. Hind tibia scarcely or no longer than the femora, straight in both sexes, slender, generally armed beneath with two median subapical spines besides the apical pair; spurs irregularly opposite, the basal at the end of the proximal third of the tibia, slightly longer than the tibial depth, set at an angle of about $45^{\circ}$ with the tibia and divaricating about $120^{\circ}$, slightly incurved especially at tip; inner middle calcaria nuch longer than the outer, more than twice as long as the others or as the spurs, and as long as the first tarsal joint. Hind tarsi about two fifths as long as the hind tibix, the first joint as long as the rest together, the second more than twice as long as the third and with it as long as the fourth. Cerci rather slender, tapering, pointed, about two thirds as long as the femoral breadth. Ovipositor twice as long as the fore femora, and about two thirds as long as the hind femora, straight, geutly tapering in the proximal, rather slender and equal in the distal half, the tip upturned and acute but not aculeate, the armature of the inner valves consisting of deep denticulations.

Length of body, § $14.5 \mathrm{~mm}$., $\$ 16 \mathrm{~mm}$. ; antennx, $\$$ (est.) $44 \mathrm{~mm}$.; vol. $\mathrm{xxx} \cdot(\mathrm{N} . \mathrm{8} . \mathrm{XX11})$ 
pronotum, of $4.6 \mathrm{~mm}$., $\& 5 \mathrm{~mm}$; fore femora, of $6 \mathrm{~mm}$., $\$ 5.5 \mathrm{~mm}$; hind femora, $\delta$ क $14 \mathrm{~mm}$.; hind tibiæ, $\delta 14.5 \mathrm{~mm}$., $\$ 14 \mathrm{~mm}$; ovipositor, $9 \mathrm{~mm}$.

7 8, 6 \&. Ithaca and Endfield Falls, N. Y. (Cornell Univ., Morse); Vigo Co., Ind. (Blatchley); Texas, Belfrage. Originally described from Illinois. Said by Bruner to be found in Eastern Nebraska, but I have seen no specimens from so far west.

\section{Ceuthophilus meridionalis, sp. nov.}

Whole dorsal surface of body dark, being mostly almost piceous with dark mahogany brown markings consisting principally of a broad mesial stripe of irregular width on the thorax, fully as broad as the basal joint of the antennæ and on the abdomen made up of numerous spots and short longitudinal or oblique bars, which toward the sides become tinged with luteous; the sides dingy luteous, the femora fuscoluteous, the hind pair externally striped with clearer luteous above and spotted below; hind femoral geniculations blackish; all the tibiæ and antennæ dark luteous. The antennæ are moderately slender, the legs rather long. Fore femora scarcely stouter than the middle femora, fully one fourth longer than the pronotum but only two fifths the length of the hind femora, the inner carina with two spines, the outer of which is hardly subapical but pretty stout. Middle femora with three pretty stout spines on the front carina, and on the hind carina from 1-4 small spiues besides a long genicular spine. Hind femora of the length of the body, about two and a half times as long as the fore femora, very stout, the apical fourth subequal, about three and a quarter times as long as broad; the upper lalf very faintly but closely scabrous in the darker portions, the outer carina elevatel, with 5-6 unequal and inequidistant large or very large spines, the largest just beyond the middle, coarse, especially at base, and much longer than the tibial spurs, besides one or two spinules in the constricted portion of the femora, the inner carina rather distantly and rather regularly spinulate throughout, the intervening sulcus very broad. Hind tibiæ gently arcuate on basal third, much longer than the femora, not very slender, armed beneath apically with two or three spines besides the apical pair; spurs subalternate, the basal at end of proximal third of the tibia, slightly longer than the tibial depth, set at an angle of $45^{\circ}$ with the tibia and divaricating about $100^{\circ}$, the apical half incurved; (calcaria and hind tarsi lost in the only specimen known). Cerci slender, gently tapering, about two thirds as long as the femoral breadth. 
Length of body, $20 \mathrm{~mm}$; antennæ, $25 \times \mathrm{mm}$; pronotum, $6.5 \mathrm{~mm}$.; fore femora, $8.25 \mathrm{~mm}$; hind femora, $20.5 \mathrm{~mm}$; hind tibiæ, $22.3 \mathrm{~mm}$.

1 s. Chihuahua, Mexico.

\section{Ceuthophilus neglectus, sp. nov.}

Ceuthophilus maculatus (pars), Scudd.!, Bost. Journ. Nat. Hist., vii. 434 (1862).

Glabrous, castaneous, more or less, often deeply, infuscated especially above, the infuscation often but not always terminatıng below the middle of the sides, which are there sordid luteous; a broad more or less and often very obscure mediodorsal rufo-luteous stripe on the pronotum, sometimes extended farther back but then generally broken; the sides of the pronotum and to a lesser extent the meso- and metanotum are more or less blotched or vermiculate with luteous, and the abdomen is more or less but generally feebly maculate with luteous; the markings and the coloring vary greatly, so that it is difficult to formulate any general statement; the female is apt to be darker than the male, and specimens from New England are often almost uniformly dark, even almost black, while the contrasts between the dorsum and the lower portion of the sides are strongest in specimens from the Middle Atlantic States, where they grow to a large size; the legs are generally luteo-castaneous, the tips of all the femora dark, sometimes almost black, the hind femora with scalariform fuscous markings. The antennæ are not often infuscated and then generally more or less or feebly annulate with luteous, slender and generally 2-3 times as long as the body, the legs rather slender and moderately short. Fore femora scarcely stouter than the middle femora, considerably less than half as long as the hind femora and but very little longer than the pronotum, the inner carina with a subapical spine, rarely accompanied by another. Middle femora with 1-3 spines (largely depending upon age) on the front carina, and on the hind carina 0-3 spines besides a longer but short genicular spine. Hind femora two and a quarter times longer than the fore femora, about as long as the body, stout and tumid, the upper and lower margins almost equally arcuate, scarcely more than the genicular portion subequal, almost three times as long as broad, the inner surface with a very few raised points next or at the upper margin beyond the middle, scarcely perceptible or absent from the female, the outer carina minutely, closely, and pretty uniformly serrulate through all but the basal third, sometimes almost imperceptible in the female, the inner carina a fecbler repetition of the outer, the intervening sulcus moderate in width. Hind tibiæ slender, 
straight in both sexes, barely or no longer than the femora, armed beneath with 1-2 subapical spines besides the apical pair; spurs subopposite, the basal at the end of the proximal third of the tibia, scarcely shorter than the tibial depth, set at an angle of about $45^{\circ}$ with the tibia and divaricating about $100-110^{\circ}$, their tips incurved; inner middle calcaria considerably longer than the outer, about twice as long as the others or as the spurs, but shorter than the first tarsal joint. Hind tarsi almost two fifths as long as the tibiæ, the first joint not so long as the rest together, the second considerably more than twice as long as the third and with it fully as long as the fourth. Cerci moderately stout, tapering rather uniformly, about two thirds as long as the femoral breadth. Ovipositor half as long as the hind tibiæ, straight, tapering in basal half, equal and moderately slender, the tip slightly upcurved and acutely pointed (about $35^{\circ}$ ), the inner valves with aculeate, scarcely arcuate teeth.

Length of body, के $\$ 12.5 \mathrm{~mm}$; pronotum, of $4.4 \mathrm{~mm}$., $\% 4.6 \mathrm{~mm}$.; fore femora, $\delta$ \& $5 \mathrm{~mm}$; hind femora, $\delta 12 \mathrm{~mm}$., $\$ 11.7 \mathrm{~mm}$; hind tibiæ, \& $\$ 12 \mathrm{~mm}$. ; ovipositor, $6 \mathrm{~mm}$.

31 ఫे, 29 \&. Ithaca, N. Y., Comstock (Cornell Univ., Morse) ; Jay, Vt. (A. P. Morse) ; Sudbury, Vt. (S. H. Scudder) ; side of Mt. Washington, N. H. (S. H. Scudder) ; Forest Hills, Mass. (S. Henshaw); Cambridge, Mass. (Mus. Comp. Zoöl.) ; Princeton, Mass. (S. H. Scudder); Pennsylvania (Mus. Comp. Zoöl.); Maryland (P. R. Uhler); Baltimore, Md. (Mus. Comp. Zoöl.); Washington, D. C. Cornell Univ., L. Bruner); Virginia (L. Bruner); West Virginia (Museum Comp. Zoöl.). In the U. S. National Museum, from C. V. Riley's collection, are $3 \delta, 2$ \&, from Maryland, District of Columbia, and Virginia.

\section{Ceuthophilus macelatus.}

Rhaphidophora maculata [Say, MS.], Harr., Treat. Ins. Inj. Veg., ed. 1841-42, 126 ; Fitch, Amer. Journ. Agric. Sc., vi. 146 (1847); Pack., Rep. Nat. Hist. Me., 1861, 375 ; Thom., Trans. Ill. St. Agric. Soc., v. 444 (1865).

Phalangopsis maculata Harr., Treat. Ins. Inj. Veg., ed. 1852, 137 ; ed. 1862, fig. 73 ; Walk., Cat. Derm. Salt. Brit. Mus., i. 116 (1869).

Ceuthophilus maculatus Scudd.! (pars), Bost. Journ. Nat. Hist., vii. 434 (1862); Pack., Rep. Nat. Hist. Me., 1862, 196; Smith, Proc. Portl. Soc. Nat. Hist., i. 145 (1868); Pack., Guide Ins., 565 (1869) ; Walk., Cat. Derm. Salt. Brit. Mus., i. 201 (1869) ; Id., Ibid., Suppl., v. 23 (1871) ; Smith, Rep. Conn. Bd. Agric., 1872, 359, 380; 
Glov., Ml. N. A. Ent., Orth., pl. 3, fig. 5 (1872); Scudd., Hitchc., Rep. Geol. N. H., i. 366 (1874); Prov., Nat. Canad., viii. 75, fig. 5 (1876) ; Putn., Proc. Dav. Acad. Sc., ii. 11 (1876) ; Bol., Ann. Soc. Ent. France (5), x. 72 (1880) ; Ril., Stand. Nat. Hist., ii. 184, fig. 259 (1884) ; Brun.?, Bull. Washb. Coll. i. 126 (1885); Caulf., Can. Ent., xviii. 212 (1886); Id., Rep. Ent. Soc. Ont., xviii. 63, 69 (1888); Brunn., Monogr. Stenop., 63 (1888); Pack., Mem. Nat. Acad. Sc., iv. 72, 116 (1888); Fern., Orth. New Engl., 19 (1888); Pack., Psyche, v. 198 (1889); Davis, Ent. Amer., v. 80 (1889); Smith, Cat. Ins. N. Jers., 409 (1890); Charlt.?, Ent. News, i. 64 (1890); Cock.?, Can. Ent., xxii. 76 (1890); McNeill, Psyche, vi. 27 (1891); Osb., Proc. Iowa Acad. Sc., i. ii. 119 (1892); Towns. ?, Ins. Life, vi. 58 (1893); Blatchl., Proc. Ind. Acad. Sc., 1892, 142-143 (1894); Cock.?, Trans. Amer. Ent. Soc., xx. 336 (1894).

Phalangopsis lapidicola Uhl, Harr. Treat. Ins. Inj. Veg., 155 (1862).

Ceuthophilus lapidicolus Brun.!, Publ. Nebr. Acad. Sc., iii. 32 (1893).

Color and markings almost precisely the same as in $C$. terrestris, so that imperfect and immature specimens are exceedingly difficult to separate; but the darker markings in this species are as a rule darker and cover the surface to a greater extent, and when the mediodorsal stripe is present it is often broader and extends upon the meso- and metanotum ; on the other hand, the maculation of the abdomen with luteous is usually more striking in the present species (partly from the darkness of the ground) and forms sometimes a tolerably regular pattern, consisting on each joint of an anterior mediodorsal triangular spot, a central subdorsal oblique dash, and posterior spots farther from the middle line. The antennæ are from two to three times as long as the body, and slender except at extreme base, and the legs are moderately long. Fore femora no stouter than the middle femora, a little more than a fourth longer than the pronotum and much less than half as long as the hind femora, the inner carina with a long subapical spine and occasionally an additional one. Middle femora with 0-2 spines besides a rather long subapical spine on the front carina, and on the hind carina an occasional small spine besides a long genicular spine. Hind femora of about the length of the body, three and a half times as long as broad, about two and a third times as long as the fore femora, moderately stout at base, the distal fifth subequal, with no raised points on the upper or inner surface, the outer carina with about thirteen unequal coarse spines, the longest hardly half as long as the tibial spurs $(\delta)$ or with minute distant inconspicuous spinules ( $\$$ ), 
the inner carina with similar but uniform spinulation, none so large as on the outer carina $(\delta)$ or with a few minute spinules on the apical half $(\$)$, the intervening sulcus not very broad. Hind tibiæ feebly undulate in the basal half in the male, slender in both sexes, distinctly but not greatly longer than the femora, armed beneath with a single preapical spine or occasionally with two minute unaligned spines besides the apical pair; spurs rudely opposite, the basal at the end of the proximal third of the tibia, more than half as long again as the tibial depth, set at an angle of about $40^{\circ}$ with the tibia and divari. cating $90-100^{\circ}$, their tips incurved; inner and outer middle calcaria subequal, more than twice as long as the others or as the spurs, and as long as the first tarsal joint. Hind tarsi about two fifths as long as the tibiæ, the first joint shorter than the rest together, the second twice as long as the third and with it longer than the fourth. Cerci stout in the proximal half, tapering beyond, about two thirds as long as the femoral breadth. Ovipositor nearly two thirds as long as the hind femora, shaped and armed as in C. terrestris.

Length of body, \& $14 \mathrm{~mm}$., $q 16$ ? mm.; pronotum, \& $5 \mathrm{~mm}$., $5.1 \mathrm{~mm}$; fore femora, of $6.6 \mathrm{~mm}$., $\% .7 \mathrm{~mm}$; hind femora,

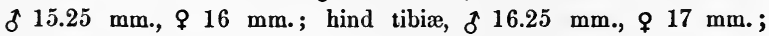
ovipositor, $10 \mathrm{~mm}$.

18 o, 9 9. Montreal, Canada, Caulfield; valleys of the White Mts., N. H.; Chateaugay Lake, Adirondacks, N. Y., 2,000', F. C. Bowditch; Ithaca, N. Y., Pearce, Pettit (Corn. Univ.); Michigan, J. G. Jack; Cape Elizabeth, Me., E. S. Morse; Blue Hills, Milton, Mass., S. Henshaw ; Mass., F. G. Sanborn; Conn., E. Norton; New York; S. Orange, N. J.; Moline, Ill., MeNeill; Vigo Co., Ind., W. S. Blatchley; Iowa City, Iowa, Shimek (Bruner). I have also seen specimens in the Museum of Comparative Zoölogy from Norway (Smith), Gorham, Cape Elizabeth (Morse), Maine, Vermont, Malden (Higgins), House Island (Cooke), Feltonville (Jilson) and Nahant, Mass. In addition to the districts mentioned above it has been reported (but may often have been erroneously taken for another species) from Howe's Cave, N. Y. (Packard), Missouri (Brunner), McPherson Co., Kansas and Nebraska (Bruner), and Colorado (Charlton, Cockerell, Townsend).

\section{Ceuthophilus tenebrarum, sp. nov.}

Ceuthophilus latens McNeill!, Psyche, vi. 27 (1891).

Body glabrous, brownish or blackish fuscous, heavily marked with luteo-castaneous, often more or less pallid, sometimes with a rufous 
tinge; the markings consist of a mediodorsal stripe of varying width but usually rather broad on the pronotum, especially a little before either border, generally reduced to a line on the abdomen, a large lateral patch on either side of the pronotum, sometimes confined to the inferior margin, sometimes extending half way to the mediodorsal line, and a conspicuous and liberal sprinkling of roundish spots, generally more or less elongated longitudinally, especially on the abdomen; the antennæ are pale fuscous and the legs sordid luteous more or less infuscated, the hind femora with heavy fuscous scalariform markings, leaving roundish dull luteous spots in the openings of the upper half. The antennæ are slender and apparently only about twice the length of the body or a little more, and the legs short though slender. Fore femora of the same slenderness as the middle femora, much less than half as long as the hind femora and a little more $(\delta)$ or a little less ( $q$ ) than a fourth longer than the pronotum, the inner carina with 1-2 small spines. Middle femora with 1-3 spines on the front carina, the subapical the longest but not long, the hind carina with rarely more than the moderately short genicular spine. Hind femora somewhat shorter than the body, about two and a half times longer than the fore femora, moderately slender, being about three and a third times as long as broad, fully the apical fourth subequal, the surface with no raised spines, the outer carina with a few distant serrations or recumbent spines on apical half $(\delta)$ or unarmed $(\$)$, the inner carina similar to the outer, the intervening sulcus narrow. Hind tibiæ straight in both sexes, not a great deal longer than the femora, armed beneath with a single subapical spine besides the apical pair; spurs subalternate, the basal at the end of the proximal third of the tibia, scarcely if any longer than the tibial depth, set at an angle of $45^{\circ}$ with the tibia and divaricating about $110^{\circ}$, their tips incurved; inner middle calcaria much longer than the outer, more than twice as long as the others or as the spurs, and nearly as long as the first joint of the tarsus. Hind tarsi fully two fifths as long as the tibiæ, the first joint almost as long as the rest together, the second twice as long as the third and with it fully as long as the fourth. Cerci slender, tapering regularly, three fourths as long as the femoral breadth. Ovipositor as long as the fore femora, straight, the apical three fifths equal and moderately slender, the apex a little upturned and subacute but not very much produced, the teeth of the inner valves consisting of blunt pointed crenations.

Length of body, \& $13.5 \mathrm{~mm}$., $\$ 12.5 \mathrm{~mm}$; pronotum, \& 3.75 mm., $\uparrow 3.8 \mathrm{~mm}$., fore femora, o $4.8 \mathrm{~mm}$., $\uparrow 4.25 \mathrm{~mm}$.; hind femora, 
क $11.75 \mathrm{~mm}$., \& $10.25 \mathrm{~mm}$; hind tibiæ, of $12.5 \mathrm{~mm}$., क $10.6 \mathrm{~mm}$; ovipositor, $4.25 \mathrm{~mm}$.

7 d , 4 \&. Port Byon, Ill., July 7 (McNeill) ; S. Illinois (Kennicott); Lexington, Ky., May, June, August (S. Garman); Bee Spring, Ky., June, Sanborn (Mus. Comp. Zoöl.); Beaufort, N. C., Shute (Mus. Comp. Zuöl.). $2 \delta, 2 \%$, from Olio are in the collection of Riley (U. S. Nat. Mus.).

\section{Ceuthophiles bicolor, sp. nov.}

Borly glabrous, luteo-testaceous, with a broad subdorsal blackish fuscous band on either side, leaving between them a broad bright stripe the whole length of the body, next the stripe sharply delimited, laterally more or less broken, ragged and fading away, narrow on the pronotum where it is infringed upon by a large central luteous spot on the sides, broader and profusely spotted with luteous posteriorly, the lower portions of the sides almost wholly pallid luteous with cloudy infuscations, the extreme margin testaceous; legs luteo-testaceous, the hind femora feebly marked with fuscous in a scalariform pattern and tipped with fuscous. The antennæ are slender and at least three times as long as the body, and the legs slender and rather short. Fore femora no stouter than the middle pair, much less than half as long as the hind femora, a fifth as long again as the pronotum, the inner carina with two or three spines, the preapical much longer than the others. Middle femora with the front carina similarly armed and the hind carina with one or two spines mesially situated besides a long genicular spine. Hind femora as long as the body, two and a half times longer than the fore femora, stout, tapering with great regularity to the slightly enlarged genicular lobes, scarcely more than three times as long as broad, the inner surface above beyond the middle with a small cluster of raised points, the outer carina armed on the stouter part of the femora with an open series of serrulations, developing distally into spines, the last two much larger than the others and balf as long as the tibial spurs, followed by $3-4$ slight spines just before and on the genicular lobes, the inner carina equally but inequidistantly and rather sparsely spinulate, the intervening sulcus broad. Hind tibiæ straight, slender, more than a tenth longer than the femora, armed beneath with a single subapical spine besides the apical pair; spurs subalternate, the basal before the end of the proximal third of the tibia, nearly or quite twice as long as the tibial depth, set at an angle of about $50^{\circ}$ with the tibia and divaricating about $110^{\circ}$, their tips incurved; inner middle calcaria greatly 
longer than the outer, more than twice as long as the others or as the spurs, and fully as long as the first tarsal joint. Hind tarsi barely two fifths as long as the tibiæ, the first joint as long as the rest together, the second three times as long as the third and with it as long as the fourth. Cerci not very slender, blunt tipped, about two thirds as long as the femoral breadth.

Length of body, $11.5 \mathrm{~mm}$; antennæ, (est.) $32+\mathrm{mm}$; pronotum, $3.75 \mathrm{~mm}$.; fore femora, $4.5 \mathrm{~mm}$; hind femora, $11.5 \mathrm{~mm}$. ; hind tibiæ, $13 \mathrm{~mm}$.

1 §. Bee Spring, Ky., June 14, F. G. Sanborn (Mus. Comp. Zoöl.).

\section{Ceuthophilus nodolosus.}

Ceuthophilus nodulosus Brunn., Monogr. Stenop., 64, fig. 33a (1888).

Luteo-castaneous, heavily marked with black ish fuscous especially along the posterior borders of all the segments and the anterior border of the pronotum, and the latter also flecked with it in an obscure fashion upon the whole disk; legs luteous, the hind femora almost lacking the usual scalariform markings. The antennæ are slender, but are apparently less than twice the length of the body, the legs short. Fore femora very slightly stouter than the middle femora, slightly $(\delta)$ or no $(q)$ longer than the pronotum and distinctly less than half as long as the hind femora, the inner carina with a feeble subapical spine, at least in the male. Middle femora generally with 3-4 small spines on the front carina, and on the hind carina 0-1 (\$) or 3-8 ( $\delta$ ) short spines besides a short genicular spine. Hind femora pretty stout, a very brief apical portion equal, a little less than three times as long as broad, considerably more than twice as long as the fore femora, all the scalariform dark portions of the surface, especially in the male, scabrous with raised points, which are also clustered about the upper portion of the inner side just beyond the middle, the outer carina elevated, with three or four inequal and irregularly distant large and rather coarse more or less arcuate spines, the longest nearly or quite as long as the tibial depth, placed in the middle half, besides a few minor spines beyond them $(\delta)$ or with 4-5 small distant spines, most of them in the constricted part of the femora ( $q$ ), the inner carina with a series of closer but in no way crowded smaller and uniform spinules, subobsolete in the female, the intervening sulcus moderate in breadth. Hind tibiæ strongly bent or bowed near the middle and subsinuate, on the middle of the proximal half compressed to form a triangular denticle on the under surface, from which a regular curve 
sweeps to an inferior slight spiniferous swelling just before the middle of the distal half $(\delta)$, shorter than the femora in both sexes, armed beneath on the distal half with a series of about three recumbent spines (in the $\delta$ arising from slight elevations) besides the apical pair; spurs subopposite, the basal well beyond the end of the distal third of the tibia, hardly more than half as long as the tibial depth, set at an angle of about $45^{\circ}$ with the tibia and divaricating about as much; inner middle calcaria somewhat longer than the outer, twice as long as the others or as the spurs but much shorter than the first tarsal joint. Hind tarsi less than two fifths the length of the tibiæ, the first joint nearly as long as the rest together, the second fully twice as long as the third and with it as long as the fourth. Cerci very short, not very slender, rapidly tapering, hardly more than half as long as the femoral breadth ( $q$ ) or developed basally as a single stout subclavate apically upturned blunt joint, surmounted by a brief conical multiarticulate appendage, the only portion which surpasses the supraanal plate $(\delta)$. Ovipositor brief and slight, no longer than the fore femora, tapering in proximal, equal in distal half, the apex and armature as in $C$. inquinatus.

Length of body, \& $13.5 \mathrm{~mm}$., $\$ 12 \mathrm{~mm}$; pronotum, \& $4 \mathrm{~mm}$, $3.8 \mathrm{~mm}$; fore femora, of $4.5 \mathrm{~mm}$., $\$ 3.6 \mathrm{~mm}$; hind femora, o $10.5 \mathrm{~mm}$., \& $8.5 \mathrm{~mm}$.; hind tibiæ, of $9.6 \mathrm{~mm}$., $\& 8 \mathrm{~mm}$; ovipositor, $3.5 \mathrm{~mm}$.

2 ठ, 2 \&. West Point, Nebr.; McPherson Co., Kans., Rundstrom, all from L. Bruner. Subsequently to the description of the above I received from the U. S. National Museum $3 \delta, 1 \%$, from Dallas, Texas, of considerably larger size, like that described by Brunner, also from Texas.

\section{Ceuthophilus valgus, sp. nov.}

Dark luteo-testaceous, more or less infuscated especially along the hind borders of all the segments and the front border of the pronotum; occasionally a few indistinct luteous dots occur in a transverse series on the abdominal segments, but most of the varied markings are confined to the pronotum, where they are not pronounced and consist of a dull luteous mediodorsal stripe and vague and irregular streaks or clouds of luteous upon either side, more or less extensive; the legs are generally lighter than the body, but are more or less infuscated beyond the base of the femora, the hind pair of which scarcely show any scalariform markings. The antennæ are not very slender, two to three times as long as the body, and the legs are moderately long and 
slender. Fore femora no stouter than the middle femora, less than a quarter longer than the pronotum and somewhat less than half as long as the hind fenora, the inner carina with a single minute spine, at least in the $\delta$, besides a distinct preapical spine. Middle femora with a single spine ( 9 ) or $2-4$ spines $(\delta)$ on the front carina, and on the hind carina about four spines (generally fewer in the $q$ ) besides a short genicular spine. Hind femora nearly as long as the body, distinctly more than twice as long as the fore femora, not very stout, being about three and a quarter times longer than broad, glabrous, the surface with no raised points, the outer carina elevated, armed with about ten unequal and inequally separated spines, the largest stouter than and about as long as the tibial spurs $(\delta)$ or scarcely elevated and unarmed ( $\$$ ), the inner carina with distant raised thick points, occasionally becoming minute spines $(\delta)$ or unarmed $(q)$, the intervening sulcus narrow. Hind tibiæ as long as the femora, straight in the $\$$, strongly bowed on proximal half in the $\delta$ (unless immature), armed beneath with a single preapical spine besides the apical pair; spurs subopposite, the basal at about the end of the proximal third of the tibia, scarcely if at all longer than the tibial depth, set at an angle of about $50^{\circ}$ with the tibia and divaricating about $100^{\circ}$, their tips incurved; inner middle calcaria about a third longer than the outer, twice as long as the others or as the spurs, but hardly more than half as long as the first tarsal joint. Hind tarsi less than half as long as the tibix, the first joint nearly as long as the rest together, the second more than twice as long as the third and with it fully as long as the fourth. Cerci stout, tapering, pointed, hardly more than half as long as the femoral breadth. Ovipositor almost as long as the hind tibix, rather slender, equal from close to the base to near the tip, gently arcuate, the tip barely upturned and pointed at an angle of not less than $50^{\circ}$, the inner valves scarcely armed, the teeth being barely indicated by a slight crenulation.

Length of body, $\delta 13 \mathrm{~mm}$., $\$ 10 \mathrm{~mm}$; pronotum, $\delta 4.7 \mathrm{~mm}$, $\$ .65 \mathrm{~mm}$; fore femora, of $5.5 \mathrm{~mm}$., $\$ 4.5 \mathrm{~mm}$.; hind femora and tibiæ, each, of $12.9 \mathrm{~mm}$., $\$ 9.4 \mathrm{~mm}$; ovipositor, $8.5 \mathrm{~mm}$.

6 ₹ , 3 ․ Colorado 7-8,000', H. K. Morrison ; South Park, Colorado, $8-10,000^{\prime}$, August 11-16, S. H. Scudder. I also place here an immature $q$ taken by me at Pueblo, Colorado, 4,700', August 30-31. Since the description was written, Mr. L. Bruner has sent me $1 \delta$, 2 \&, from Brush Creek, Custer Co., Colorado, 10,000'. and Granite, Colorado. 


\section{Ceuthophilus divergens.}

Ceuthophilus divergens Scudd.!, Bost. Journ. Nat. Hist., vii. 436 (1862) ; Walk., Cat. Derm. Salt. Brit. Mus., i. 201 (1869); Thom. ?, Proc. Acad. Nat. Sc. Philad., 1870, 77 ; Id. ?, Ann. Rep. U. S. Geol. Geogr. Surv. Terr., ii. 265, 269 (1871) ; Id.?, Bull. U. S. Geol. Geogr. Surv. Terr., iv. 485 (1878); Ril., Stand. Nat. Hist., ii. 184 (1884); Blatchl., Proc. Ind. Acad. Sc., 1892, 153 (1894).

Body subglabrous, dark blackish fuscous above, passing on the sides into rufo-testaceous more or less tinged with luteous, and with blotches and irregular spots of the same above; especially to be noted are a mediodorsal rufo-luteous interrupted stripe and on the sides of the pronotum a large spot of the same much vermiculate with fuscous; the abdomen is also more or less spotted with the same; the legs are dingy luteous, all the femora tipped with fuscous and the hind femora heavily marked with fuscous in a scalariform pattern. The antennæ are moderately slender and three or four times as long as the body, and the legs are rather long and slender, with prominent spines. Fore femora no stouter, but in the male slightly shorter, than the middle femora, much less than half as long as the hind femora and but little longer than the pronotum, the inner carina with 2-3 spines, the subapical long. Middle femora with 2-3 spines on the front carina, the subapical longest, and on the hind carina two small spines besides a long genicular spine. Hind femora about as long as the body, about two and a half times longer than the fore femora, moderately stout particularly in the male, where they are less than three and a half times while in the female they are nearly four times as long as broad, the middle of the inner surface in the male with a considerable cluster of raised points on the upper half, the outer carina with about ten unequal stout teeth the largest shorter but stouter than the tibial spurs $(\delta)$ or apically with a series of subdued serrulations ( $q$ ), the inner carina in $q$ armed like the outer carina but very inconspicuously, in the $\delta$ as in the $q$ but more conspicuously, the intervening carina narrow. Hind tibiæ scarcely longer than the femora, straight in both sexes, slender, distinctly though feebly constricted at the base, faintly enlarging above toward the apex, armed beneath with a single subapical spine besides the apical pair ; spurs subalternate, the basal at the end of the proximal fourth of the tibia, nearly or quite twice as long as the tibial depth, set at an angle of about $70^{\circ}$ with the tibia and divaricating from $130^{\circ}$ to $180^{\circ}$, their tips incurved; inner middle calcaria much longer than the outer, fully twice as long as the others or as the spurs, and as long as 
the first tarsal joint in the $\delta$, scarcely so long in the $q$. Hind tarsi less than half as long as the hind tibix, the first joint almost equalling the rest together, the second much more than twice as long as the third and with it about as long as the fourth. Cerci rather stout and short, hardly exceeding in length half the femoral breadth. Ovipositor nearly straight and short, shorter than the fore femora, the basal half tapering, the apical half sleuder and equal, the tip more than usually upturned and produced to a very acuminate point, the teeth of the inner valves long, aculeate, arcuate.

Length of body, శᄒ $12 \mathrm{~mm}$., \& $13 \mathrm{~mm}$; antenuæ, (est.) $\delta 40 \mathrm{~mm}$., क $48 \mathrm{~mm}$.; pronotum, o $4.5 \mathrm{~mm}$., \& $5 \mathrm{~mm}$.; fore femora, $\delta 5.4 \mathrm{~mm}$., $5.25 \mathrm{~mm}$; hind femora, $\delta 13.5 \mathrm{~mm}$., $\$ 12.75 \mathrm{~mm}$; hind tibix, के $13.75 \mathrm{~mm}$., $\% 13 \mathrm{~mm}$; ovipositor, $4.75 \mathrm{~mm}$.

1 §, 2 \%. Nebraska, A. Agassiz (Mus. Comp. Zoöl.). Thomas reports it from several localities in Colorado, Wyoming, Dakota, and Montana, but it is quite as likely as not that some other species was mistaken for it. The one reported by Osborn and Bruner from Iowa and Nebraska is the one here described as C.bruneri.

\section{Ceuthophilus occultus, sp. nov.}

Body castaneous, more or less and irregularly blotched above with feeble fuscous markings, most couspicuous on the pronotum and absent from a narrow irregular and sometimes broken median stripe of the ground color, which does not extend upon the abdomen; abdomen obscured with fuscous on the posterior margins of the segments. Legs luteo-castaneous, the outside of the hind femora with the usual markings nearly obsolete. Antennæ very long and slender, the legs moderately long. Fore femora a little stouter than the middle femora, about a sixth longer than the pronotum, and half or less than half as long as the hind femora, the inner carina armed with a long preapical spine and sometimes with another short one. Middle femora with a long preapical spine on the front carina, sometimes accompanied in the $q$ by 1-2 others, the hind carina with a long genicular spine accompanied by $2-3$ spines in the $\delta$. Hind femora of about the length of the body in the $\delta$, about twice ( $\$$ ) or distinctly more than twice $(\delta)$ as long as the fore femora, rather slender, being nearly four times as long as broad, without conspicuous raised points on the surface, the outer carina elevated, with 5-6 distant spinules, the largest very small $(\delta)$ or not elevated, with many minute serrulations on the apical half $(q)$, the inner carina with numerous delicate spinules $(\delta)$ or similar to the other carina ( $)$. Ilind tibix straight, distinctly longer 
than the femora, beneath with a single preapical spine besides the apical pair; spurs subopposite, the basal before the end of the proximal fourth of the tibiæ, long and delicate, being nearly twice as long as the tibial depth, set at an angle of about $45^{\circ}$ with each other and divaricating about $110^{\circ}$, their tips incurved. Inner middle calcaria a little longer than the outer, twice as long as the others and nearly twice as long as the spurs, as long as the first tarsal joint. Hind tarsi two fifths as long as the tibiæ, the first joint as long as the others together, the fourth about equalling the second and third together. Cerci pretty stout at base, tapering throughout, pointed, longer than the femoral breadth. Ovipositor nearly two thirds as long as the hind femora, pretty stout at base, the distal two thirds equal and rather slender, the apex produced to a fine spinous point and the teeth of the inner valves prominent and sharp, the proximal subdenticulate, the others acicular and arcuate.

Length of body, \& $11 \mathrm{~mm}$., $\$ 12 \mathrm{~mm}$.; antennæ, (est.) \& $30 \mathrm{~mm}$., \$ $25 \mathrm{~mm}$; pronotum, $\delta 4 \mathrm{~mm}$., $\$ 3.75 \mathrm{~mm}$; fore femora, $\delta 4.7$ mm., \& $4.5 \mathrm{~mm}$; hind femora, of $10.5 \mathrm{~mm}$., $\& 8.5 \mathrm{~mm}$; hind tibiæ, of $11.5 \mathrm{~mm}$., \& $9 \mathrm{~mm}$. ; ovipositor, $5.25 \mathrm{~mm}$.

1 ช̊, 2 \%. Georgia, Morrison.

\section{Ceuthophilus alpinus, sp. nov.}

Luteo-testaceous, traversed by distinct and rather broad fuscous bands at the incisures of all the segments (about equally on the anterior and posterior margins) which fade out more or less on the lower portion of the sides; pronotum with two broad subdorsal longitudinal fuscous bars, extending across at least the anterior half of the segment, leaving between them a slender mediodorsal luteous stripe; legs luteo-testaceous, scarcely at all infuscated excepting on the hind femora which sometimes show coarse and obscure scalariform markings. The antennæ are moderately slender and probably do not twice exceed the length of the body, and the legs are short. Fore femora scarcely if at all stouter than the middle femora, but very little longer than the pronotum, about half as long as the hind femora, the inuer carina with a subapical spine only. Middle femora armed with 1-2 (q) or 3-4 (ठ) spinules on the front carina, and on the hind carina with 1-2 spinules besides a short genicular spine. Hind femora very much shorter than the body, twice as long as the fore femora, moderately stout, being scarcely more than three times as long as broad, and the enlarged portion long, the surface with exceedingly few scattered raised points on the upper half beyond the middle, the outer carina 
uniformly and rather finely serrulate, more finely in the $q$ than in the $\delta$, the inner carina with similar but finer and less frequent serrulations or spinules, the intervening sulcus narrow. Hind tibiæ as long as the femora, straight in both sexes, armed beneath with two distant median spines besides the apical pair; spurs opposite for the most part, the basal at the end of the proximal third of the tibia, no longer than the tibial depth, set at an angle of $45^{\circ}$ to the tibia, and divaricating about $60^{\circ}$, their tips incurved; inner middle calcaria of about the same length as the outer, less than twice as long as the others or as the spurs, and fully two thirds as long as the first tarsal joint. Hind tarsi almost half as long as the tibiæ, the first joint distinctly shorter than the rest together, the second twice as long as the third, and with it as long as the fourth. Cerci stout on the basal half, tapering beyond, shorter than the femoral breadth. Ovipositor stout at extreme base, suddenly narrowing to a slender almost straight blade, nearly two thirds as long as the hind tibiæ, the teeth of the inner blades aculeate, arcuate, and long.

Length of body, \& $13 \mathrm{~mm}$., $\& 12.5 \mathrm{~mm}$; pronotum, \& $3.9 \mathrm{~mm}$., \& $3.4 \mathrm{~mm}$.; fore femora, of $4.4 \mathrm{~mm}$., $\$ 3.8 \mathrm{~mm}$; hind femora and tibiæ, each, of $9 \mathrm{~mm}$., \& $7.6 \mathrm{~mm}$; ovipositor, $4.85 \mathrm{~mm}$.

2 J, 2 \&. South Park, Colorado, 8-10,000', Aug. 11-16, S. H. Scudder; Mt. Lincoln, Colorado, 11-13,000', above timber, Aug. 13, S. H. Scudder.

\section{Ceuthophilus bruneri, sp. nov.}

Ceuthophilus divergens Osb., Proc. Iowa Acad. Sc., i., ii. 119 (1892); Brun.! (pars), Publ. Nebr. Acad. Sc., iii. 32 (1893).

Obscure brownish fuscous, with luteous markings which are very dull and inconspicuous except in the bordering of the inferior margins of the thoracic segments; they are mostly found in large blotches of very irregular form on the sides of the pronotum and in smaller lateral and dorsal anterior spots on the other segments, sometimes confluent and the lateral often crossing the abdominal segments ; there is sometimes an interrupted mediodorsal thread; legs luteous, much infuscated especially on either side of the femoro-tibial articulation, the hind femora very broadly marked with blackish fuscous in a scalariform pattern. The antennæ are slender and about three times as long as the body, and the legs slender but not very long. Fore femora no stouter than the middle pair, much less than half as long as the hind femora and only about a sixth longer than the pronotum, the inner carina with a long preapical spine sometimes accompanied by a shorter 
one. Middle femora with 2-3 spines, the preapical long on the front carina, the hind carina with a very long genicular spine and sometimes an additional shorter one. Hind femora considerably more than twice as long as the fore femora, about as long as the body, the upper margin more arcuate than the lower, moderately slender, about three and a quarter times longer than broad, less than the apical fourth subequal, the surface with no raised points, the outer carina with two or three very feeble distant serrulations in the apical third $(\delta)$ or unarmed (q), the inner carina with distant raised points, the intervening sulcus narrow. Hind tibiæ straight in both sexes, very slender, slightly longer than the femora, armed beneath with 1-2 median spines besides the apical pair ; spurs subopposite, the basal at the end of the proximal fourth of the tibia or a little beyond it, usually fully twice as long as the tibial depth, set at an angle of about $60^{\circ}$ with the tibia and divaricating about $130^{\circ}$ (rather less in the \&), their tips incurved; inuer middle calcaria considerably longer than the outer, more than twice as long as the others, about twice as long as the spurs and a little longer than the first joint of the tarsi. Hind tarsi more than two fifths as long as the tibix, the first joint as long as the others combined, the second more than twice as long as the third and with it as long as the fourth. Cerci tapering throughout, but especially in the basal half, nearly as long as the femoral breadth. Ovipositor fully two thirds as long as the hind femora, straight, tapering strongly in basal half, beyond equal and slender, the tip strongly upcurred and very acute, the teeth aculeate, arcuate.

Length of body, \& $11 \mathrm{~mm}$., $\$ 14 \mathrm{~mm}$; pronotum, \& $3.9 \mathrm{~mm}$., \& $4.25 \mathrm{~mm}$.; fore femora, $\delta 4.5 \mathrm{~mm}$., \& $5 \mathrm{~mm}$; hind femora, $\delta 10.5$ mm., \& $11 \mathrm{~mm}$; hind tibiæ, \&े $11 \mathrm{~mm}$., \& $11.4 \mathrm{~mm}$.; ovipositor, $7.5 \mathrm{~mm}$.

4 శ, 5 q. Lincoln, West Point, and Chadron, Dawes Co., Nebr. (L. Bruner, Corn. Univ.); Sedgwick Co., Kans., S. S. Tucker (Univ. Kans., through L. Bruner); Gulf Coast of Texas, S. F. Aaron. Osborn also reports it from Iowa.

Mr. Bruner has also sent me from Carrizo Springs, Texas, two males of a much larger size, in which the body is almost completely infuscated, so that the markings of the thorax cannot or can scarcely be seen. The following measurements are taken from one of them: length of body, $16.5 \mathrm{~mm}$.; pronotum, $5.5 \mathrm{~mm}$.; fore femora, $6.9 \mathrm{~mm}$. ; hind femora, $15.5 \mathrm{~mm}$; hind tibiæ, $16.5 \mathrm{~mm}$. 


\section{Ceuthophlus agassizil.}

Rhaphidophora agassizii Scudd.!, Proc. Bost. Soc. Nat. Hist., viii. 11 (1861).

Ceuthophilus agassizii Scudd.!, Bost. Journ. Nat. Hist., vii. 439 (1862); Walk., Cat. Derm. Salt. Brit. Mus., i. 202 (1869); Brunn., Monogr. Stenop., 65 (1888).

Ceuthophilus zonarius Walk., Cat. Derm. Salt. Brit. Mus., i. 203 (1869).

Body luteous, more or less infuscated in irregular patches which especially form broad bands on the posterior margins of the segments and leave the pronotum irregularly blotched, the fuscous portions occupying the anterior and posterior and usually also the lateral margins, sometimes broken along the middle line, and running backward from the anterior margins in a pair of large subdorsal stripes, the fuscous portions often dotted with distinct luteous dots. The hind femora are marked in the usual compound scalariform manner with fuscous, which unites distally in two elongate patches on the lower half of the outer surface. Antennæ more than twice as long as the body, not very slender. Legs moderately long. Fore femora distinctly broader than the middle femora, a fifth longer than the pronotum, and at least in the $\delta$ considerably less than half as long as the hind femora, the inner carina with a preapical spine, and at least in the $\delta$ with 3 or 4 other unequal spines. Middle femora with 4-5 unequal spines on the front carina besides a preapical spine, and on the hind carina numerous unequal spines, especially in the male, besides a rather long genicular spine. Hind femora as long as the body, stout, the apical fifth subequal, about three times as long as broad, with scattered raised points on the distal half, especially above, the outer carina with a tolerably uniform series of very short spines or serrations, the inner carina with similar but finer serrations. Hind tibiæ of the same length as the femora or ( $\delta$ ) scarcely longer, straight in both sexes or feehly sinuate in old males, moderately stout, armed beneath with 1-2 preapical spines besides the apical pair; spurs subopposite, about the length of the tibial depth, set at an angle of $35-40^{\circ}$ with the tibia and divaricating about $80^{\circ}$, their tips incurved; inner middle calcaria a little longer than the outer, fully half as long again as the others or as the spurs, but much shorter than the first tarsal joint. Hind tarsi about two fifths the length of the hind tibiæ, the first joint about as long as the rest together, the second twice as long as the third and with it shorter than the fourth. Cerci tapering regu- 
larly, from a half to two thirds as long as the femoral breadth. Ovipositor fully two thirds as long as the hind femora, rather slender and equal in the distal half, the distal teeth of the inner valves long, slender, and arcuate, the proximal obsolescent.

Length of body, \& $17 \mathrm{~mm}$., \& $12.5 \mathrm{~mm}$; ; antennæ, d circ. $36 \mathrm{~mm}$.; pronotum, of $6.25 \mathrm{~mm}$., $\$ 4.6 \mathrm{~mm}$; fore femora, of $7.5 \mathrm{~mm}$., ? 6.2 mm.; hind femora, of $18 \mathrm{~mm}$., $912.5 \mathrm{~mm}$; hind tibix, of $18.5 \mathrm{~mm}$., \$ $12.5 \mathrm{~mm}$. ; ovipositor, $9.5 \mathrm{~mm}$.

$10 \delta, 1 \%$. Islands in the Gulf of Georgia, between Vancouver Isl. and the State of Washington, A. Agassiz ; Vancouver Isl., H. Edwards; Oregon; British Columbia, G. W. Taylor in Bruner's coll. Through misunderstanding Brunner von Wattenwyl has credited this also to the State of Georgia.

\section{Ceuthophilus mexicands, sp. nov.}

Pallid, probably in life luteous, heavily overlaid with dark fuscous markings; pronotum mostly fuscous, with a mediodorsal luteous thread, expanding near anterior and posterior margins into a small rhomboid spot and with a large posterior central luteous spot in the middle of each side, the extreme inferior margin also luteous; mesoand metanotum with a large central luteous spot on either side often reaching the border posteriorly and a posterior median similar spot, the two sometimes confluent and often very irregular; abdominal segments, when darkest, with a large luteous spot on each side and a median anterior one, but the fuscous is often largely reduced; legs luteous, more or less infuscated, especially on the distal halves of the fore and middle femora, the hind femora rather heavily marked with fuscous in a scalariform pattern. Antennæ very slender, at least three times as long as the body, the legs slender and rather long. Fore femora scarcely stouter than middle femora, a fourth longer than the pronotum and half as long as the hind femora, the inner carina with two spines, both long but especially the subapical. Middle femora with 1-2 spines besides a very long subapical spine on the front carina, and the hind carina with 1-2 spines besides a long genicular spine. Hind femora as long as the body and twice as long as the fore femora, rather stout at base but slender in the distal third, nearly three times as long as broad, with a few feeble raised points on the distal half of the extreme upper surface, the outer carina with 1-4 very small distant spines on the apical half, the inner carina with 8-10 minute points, the intervening sulcus narrow. Hind tibiæ straight, slender, somewhat longer than the femora, armed beneath with a single subapical spine 
besides the apical pair; spurs subopposite, the basal at the end of the proximal fourth of the tibia, considerably longer than the tibial depth, set at an angle of $35-40^{\circ}$ with the tibia and divaricating about $100^{\circ}$, their tips incurved; inner middle calcaria considerably longer than the outer, more than twice as long as the others or as the spurs, and nearly or quite as long as the first tarsal joint. Hind tarsi about two fifths the length of the tibiæ, the first joint as long as the rest together, the second fully twice as long as the third and with it rather longer than the fourth. Cerci rather long and tapering, fully as long as the femoral breadth.

Length of body, $10 \mathrm{~mm}$; pronotum, $4 \mathrm{~mm}$; fore femora, $5 \mathrm{~mm}$; hind femora, $9.8 \mathrm{~mm}$; hind tibiæ, $10.5 \mathrm{~mm}$.

6 §. San Pedro, Cohahuila, Mexico, May 20 ; San Lorenzo, Cohahuila, Mexico, found in a cave among mummies, E. Palmer.

\section{Ceuthophilus pallescens.}

Ceuthophilus pallescens Brun.!, Can. Ent., xxiii. 37-38 (1891); Id.!, Publ. Nebr. Acad. Sc., iii. 32 (1893).

Very pallid luteous, marked with fuscous and blackish fuscous, the latter in the posterior bordering of all the segments, the former in obscure blotches on the pronotum and along its front margin, more obscure in some specimens than in others; a mediodorsal luteous thread breaks most of the fuscous markings of the body; the legs are very pallid luteous, sometimes infuscated on the distal portions of the femora and especially in scalariform markings, never deep, upon the hind femora ; the spines of the legs are all dusky tipped; eyes black. The antennæ are slender and from twice to thrice the length of the body, and the legs are rather long and slender. Fore femora scarcely if any broader than the middle femora, about a fifth longer than the pronotum and half as long as the hind femora, the inner carina with a subapical spine sometimes accompanied by a shorter spine. Middle femora with 4-5 delicate spines, the subapical longer than the others on the front carina, and on the hind a similar series besides a not very long genicular spine. Hind femora much shorter than the body, twice as long as the fore femora, rather slender, being about three and a half times longer than broad, tapering pretty regularly to the tip with no genicular swelling, the surface with a few very scattered raised points especially on the inner side and above beyond the middle, both carinæ minutely and rather distantly serrulate, the intervening sulcus slender. Hind tibia straight in both sexes, considerably longer than the femora, rather slender, apically armed beneath with a series of three recum- 
bent spines besides the apical pair ; spurs subopposite, the basal beyond the end of the proximal third of the tibia, fully as long as the tibial depth, set at an angle of about $50^{\circ}$ with the tibia and divaricating about $90^{\circ}$, feebly incurved at tip; inner middle calcaria considerably longer than the outer, twice as long as the others and nearly twice as long as the spurs, but very much shorter than the first tarsal joint. Hind tarsi fully two fifths the length of the tibia, the first joint fully equal to the rest together, the second twice as long as the third and with it as long as the fourth. Cerci slender and regularly tapering, about as long as the femoral breadth. Ovipositor of exceptional length, being nearly as long as the hind femora, very feebly arcuate, slender throughout but especially beyond the proximal third, the tip scarcely upturned more than the uniform arcuation and produced to an angle of only about $40^{\circ}$, the teeth of the inner valves more distant than usual, aculeate but not long, arcuate.

Length of body, \& $8.5 \mathrm{~mm}$., \& $18 \mathrm{~mm}$.; pronotum, \& $3 \mathrm{~mm}$., \& 5 mm. ; fore femora, $\delta 3.5 \mathrm{~mm}$., $\$ 6.1 \mathrm{~mm}$.; hind femora, $\delta 7.5 \mathrm{~mm}$., \$ $12 \mathrm{~mm}$.; hind tibiæ, $88 \mathrm{~mm}$., \& $13.5 \mathrm{~mm}$; ovipositor, $11.25 \mathrm{~mm}$.

$1 \delta, 29$. Hat Creek, Nebr., in wells; Pine Ridge, Nebr., Aug. 4, under timber; Hecla, Wyo.; all from L. Bruner. The $\delta$ from Pine Ridge is rather immature.

\section{Ceuthophilus sylvestris.}

Ceuthophilus sylvestris Brun.!, Bull. Washb. Coll., i. 126-127 (1885).

Nearly uniform mahogany brown, glabrous, very faintly and broadly infuscated at the hinder margins of all the segments and on the front margin of the pronotum, the lateral margins of the thoracic segments very faintly bordered with obscure luteous; legs uniformly of a lighter tint than the body, the hind femora without scalariform markings. Antennæ slender, more than twice as long as the body, the legs moderately short. Fore femora no stouter than the middle femora, scarcely longer than the pronotum, half as long as the hind femora, the inner carina with a short subapical spine. Middle femora with only a single small spine or occasionally a second on either carina besides the posterior genicular spine. Hind femora moderately stout, tapering regularly to the tip with no pregenicular constriction or genicular enlargement, fully three times as long as broad, twice as long as the fore femora, with no raised points upon the surface, both carinæ (\$) with the most delicate possible uniform and not crowded serrulation, the intervening sulcus narrow. Hind tibiæ considerably longer 
than the femora, slender; if armed beneath, so slightly as not to be seen with an ordinary hand-glass; spurs subopposite, the basal at about the end of the proximal third of the tibia, rather longer than the tibial depth, set at an angle of about $35^{\circ}$ with the tibia and divaricating about $70^{\circ}$, their tips scarcely incurved; inner middle calcaria considerably longer than the outer, twice as long as the others or as the spurs, but shorter than the first tarsal joint. Hind tarsi almost half as long as the tibiæ, the first joint not so long as the others combined, the second about twice as long as the third and with it shorter than the fourth. Cerci slender, tapering, finely pointed, slightly longer than the femoral breadth. Ovipositor straight, considerably more than two thirds as long as the hind femora, gently tapering in proximal, slender in distal half, the tip upturned to an excessively fine point, the teeth produced, triangular, subaculeate.

Length of body, $97 \mathrm{~mm}$.; pronotum, $3 \mathrm{~mm}$.; fore femora, $3.1 \mathrm{~mm}$.; hind femora, $6.1 \mathrm{~mm}$; hind tibiæ, $7 \mathrm{~mm}$; ovipositor, $4.4 \mathrm{~mm}$.

2 \&. Topeka, Kans., F. W. Cragin, through L. Bruner.

\section{Ceuthophilus crassus, sp. nov.}

Specimens preserved after immersion in alcohol are dark fuscous and very dull castaneous, the former prevailing, the latter seen on the anterior borders of the abdominal segments in a median thoracic line, irregular transverse bands on the middle of the meso- and metanotum, and irregular blotches on the pronotum, mostly sublinear and very angular; the legs are prevailingly dusky except at base. Antennæ imperfect in all specimens but probably twice as long as the body. Legs rather short. Fore femora distinctly broader than the middle femora, but little longer than the pronotum and much less than twice as long as the hind femora, the inner carina with two small semirecumbent spines, one of them subapical. Middle femora with 3-4 small spines on the inner carina, one subapical, and on the hind carina 3-4 similar spines besides a small genicular spine. Hind femora considerably more than twice as long as the fore femora, much shorter than the body, stout, tapering to the tip with no pregenicular constriction, scarcely more than two and a half times longer than broad, with a very few scattered raised points on the upper surface apically, the outer carina finely and sparsely serrulate throughout, more densely in the $\delta$ than in the $\$$, the inner carina similar, the intervening sulcus narrow. Hind tibix straight in both sexes, scarcely or no longer than the femora, moderately stout, armed beneath with a single subapical spine besides the apical pair; spurs subopposite, the basal pair 
at the end of the proximal fourth of the tibia, not much longer than the tibial depth, set at an angle of $30-40^{\circ}$ with the tibia and divaricating about $60^{\circ}$, faintly incurved; inner middle calcaria somewhat longer than the outer, nearly twice as long as the others, twice as long as the spurs, and as long as the first tarsal joint. Hind tarsi much less than half as long as the tibiæ the first joint hardly equalling the rest taken together, the second twice as long as the third and with it a little shorter than the fourth. Cerci rather short and slender. Ovipositor two thirds the length of the hind femora, rapidly tapering at base, the distal half slender, the armature of the inner valves acicular, arcuate.

Length of body, \& $13 \mathrm{~mm}$., $\$ 17.5 \mathrm{~mm}$; pronotum, of $4.5 \mathrm{~mm}$., $?$ $5.6 \mathrm{~mm}$. ; fore femora, $\delta 5 \mathrm{~mm}$., $\$ 6 \mathrm{~mm}$.; hind femora, $\delta 11.25 \mathrm{~mm}$.,

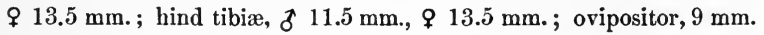

1 o, 3 \&. Locality unknown; probably from one of the Southwestern States. It is a very robust species.

\section{Ceuthophilus pinguis, sp. nov.}

Of mingled fuscous and luteo-castaneous, sometimes one, sometimes the other prevailing; when it is the latter, the fuscous shows itself on either side of the mediodorsal line in a series of subtriangular subdorsal patches seated upon the posterior margin of the segments, much larger on the thoracic than on the abdominal and partially or wholly absent from some of the latter; besides there is a series of lateral blotches, just failing to reach the lower margins of the nota and more extended on each segment anteriorly than posteriorly; on the pronotum these two sets blend irregularly, so that here the darker colors prevail; the hind femora are more or less infuscated with the markings common to the genus, more or less distinct, the geniculations laterally blackish. Antennæ moderately stout. Legs not very elongate. Fore femora basally somewhat stouter than the middle femora, considerably less than half as long as the hind femora, about a fourth longer than the pronotum, the inner carina with $2-3$ spines, the subapical and sometimes one or both the others pretty large. Middle femora with the front carina as in the fore femora, the hind carina. with 1-2 spines near the middle besides a very long genicular spine. Hind femora a little shorter than the body, considerably more than twice as long as the fore femora, very stout and broad, being considerably less than three times as long as broad, with a preapical broad constriction, so that the distal fourth is subequal, the apical half covered very sparsely except beneath with raised spinous points 
of a reddish color, the outer carina armed with 3-4 very small subequal irregularly distant spines, the inner with a dozen spinules irregularly placed, the intervening sulcus not very broad. Hind tibix straight, about a tenth longer than the femora, armed beneath with a single preapical spine besides the apical pair; spurs subopposite, the basal at end of basal fourth of the tibia, fully twice as long as the tibial depth, set at an angle of about $30^{\circ}$ with the tibia and divaricating scarcely more than $90^{\circ}$, their tips incurved distinctly; inner middle calcaria twice or more than twice as long as the others or as the spurs and as long as or longer than the first tarsal joint. Hind tarsi fully two fifths the length of the tibiæ, the first joint almost or quite as long as the rest together, the second more than twice as long as the third and with it as long as the fourth. Cerci pretty stout at base, tapering delicately, probably as long as the femoral breadth (broken in all specimens seen).

Length of body, $16 \mathrm{~mm}$.; antennæ, $28+\mathrm{mm}$. ; pronotum, $5.1 \mathrm{~mm}$.; fore femora, $6.5 \mathrm{~mm}$; hind femora, $14.6 \mathrm{~mm}$.; hind tibix, $16 \mathrm{~mm}$. One imperfect specimen is nearly half as large again.

4 8. Eagle Pass, Texas, C. O. Schott.

\section{Ceuthophilus inquinatus, sp. nov.}

Ceuthophilus divergens Brun.! (pars), Publ. Nebr. Acad. Sc., iii. 32 (1893).

Deep blackish fuscous, almost black, marked slenderly with luteous which dorsally is tinged with reddish ; there is a mediodorsal line, expanding near the posterior margin of the pronotum, on the middle of the meso- and metanotum, and on the anterior margin of the abdominal segments into small subtriangular or sublozenge-shaped patches, and crossed near the anterior margin of the pronotum by a short transverse bar sometimes forming a rhomb; the sides of the segments and particularly of the pronotum are marked in the middle by irregular luteous blotches and the lateral margins of the thoracic segments are bordered with the same more or less conspicuously; the hind femora are dark luteous with heavy scalariform markings of black and with longi.tudinal streaks of blackish fuscous on either side of the submedian clear stripe apically; other femora luteous like the rest of the legs, but more or less infuscated, especially apically. Antennæ moderately sleuder and probably long; legs moderately long. Fore femora not stouter than middle femora, less than a fourth longer than the pronotum and distinctly less than half as long as the hind femora, the inner carina with a very long subapical spine, sometimes accompanied by 
one or two others. Middle femora with the front carina armed as in the fore femora, the hind carina the same but the apical spine genicular and very long. Hind femora broad but not heavy, scarcely more than three times as long as broad, tapering rather rapidly so that the distal fourth is subequal, considerably more than twice as long as the fore femora, with half a dozen raised points on the upper surface beyond the middle, the outer carina with four or five serrations next the narrowest portion of the femora and before it half a dozen widely separated inequidistant spines, of which two or three just beyond the middle of the femora are larger than the others and rather coarse, the longest no longer than the tibial spurs $(\delta)$ or wholly unarmed except for two or three inconspicuous pregenicular spinules ( $\$$ ), the inner carina with a series of rather distant slight spinules, slighter and less frequent in the $q$ than in the $\delta$, the intervening sulcus moderate. Hind tibiæ straight in both sexes or with the faintest possible arcuation in the $\delta$, distinctly though not greatly longer than the femora, armed beneath with a single preapical spine, besides the apical pair; spurs subalternate, the hasal placed before the end of the proximal fourth of the tibia, nearly or quite twice as long as the tibial depth, set at an angle of about $50^{\circ}$ with the tibia and divaricating about $110^{\circ}$, their tips feebly incurved; inner middle calcaria but little longer than the outer, considerably more than twice as long as the others, nearly twice as long as the spurs, and slightly longer than the first tarsal joint. Hind tarsi two fifths the length of the tibia, the first joint about as long as the rest together, the second twice as long as the third and with it about the length of the fourth. Cerci rather stout at base, tapering beyond, not so long as the femoral breadth. Ovipositor more than three fifths the length of the hind femora, straight, tapering on proximal half or less, beyond moderately slender, the tip upturned and produced to an extremely acute point, the teeth of the inner valves aculeate and more or less arcuate.

Length of body, \& $13.5 \mathrm{~mm}$., $\$ 13 \mathrm{~mm}$; pronotum, of $4.3 \mathrm{~mm}$., \& $5 \mathrm{~mm}$.; fore femora, $\delta$ \& $5.5 \mathrm{~mm}$; hind femora, \& $12.25 \mathrm{~mm}$., \$ $12.5 \mathrm{~mm}$; hind tibiæ, ठ $14 \mathrm{~mm}$., $\$ 13 \mathrm{~mm}$; ovipositor, $8 \mathrm{~mm}$.

2 子, 1 \&. Fairbury, Nebr., Dr. Eaton; Lincoln, Nebr.; both through Mr. L. Bruner.

\section{Ceuthophilus discolor, sp. nov.}

Body blackish fuscous, almost black with luteous markings, as follows: a mediodorsal series of moderately large roundish spots, two on the pronotum and one on each of the succeeding segments more or 
less distinctly connected by a luteous thread; on the middle of each side of each segment a transverse dash, on the abdominal segments more elongated than on the thoracic, and generally partly merged in the mediodorsal spot, on the pronotum larger than elsewhere and accompanied by some outlying dots; also as an inferior margining of the thoracic segments; but all these markings may become so enlarged as to make the surface prevailingly luteous; the femora are fuscous, becoming lutescent toward the base, on the hind pair as heavy scalariform markings, on the anterior pairs as slender stripes. The antennæ are brownish luteous, rather slender and apparently about three times the length of the body, the legs rather short and slender. Fore femora no stouter than the middle femora, less than a fourth longer than the pronotum, much less than half as long as the hind femora, the inner carina with a long subapical spine, sometimes accompanied by another minute spine. Middle femora with a very long subapical spine accompanied by a smaller one on the front carina, and the hind carina with a long genicular spine only. Hind femora much shorter than the body, but about two and a quarter times longer than the fore femora, rather slender, being nearly three and a quarter times longer than broad, the apical fourth subequal, the surface with a few raised points scattered here and there beyond the middle of the upper half of the femora both inside and outside, the outer carina with seven or eight small unequal and inequidistant recumbent denticulations on the apical half $(\delta)$ or apparently unarmed $(\$)$, the inner carina with some very distant and very slight serrulations, the intervening sulcus slender. Hind tibiæ straight in both sexes, distinctly longer than the femora, slender, armed beneath with a single preapical spine besides the apical pair; spurs subopposite, fully twice as long as the tibial depth, set at an angle of about $35-45^{\circ}$ with the tibia, and divaricating about $90-100^{\circ}$, their tips considerably incurved; inner middle calcaria scarcely longer than the outer, more than twice as long as the others, nearly twice as long as the spurs and about as long as the first tarsal joint. Hind tarsi two fifths the length of the tibiæ, the first joint fully as long as the rest together, the second more than twice as long as the third and with it nearly or quite as long as the fourth. Cerci rather slender, tapering regularly, about as long as the femoral breadth. Ovipositor more than two thirds as long as the hind femora, straight, beyond the proximal third very slender, the tip upturued abruptly and produced to an aculeate point, the teeth of the inner valves aculeate, pretty long and arcuate.

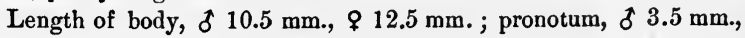


Q $3.75 \mathrm{~mm}$; f fore femora, of $4.25 \mathrm{~mm}$., $\$ 4.1 \mathrm{~mm}$; hind femora, ช $99.5 \mathrm{~mm}$. ; hind tibiæ, of $\$ 10.5 \mathrm{~mm}$. ; ovipositor, $6.75 \mathrm{~mm}$.

1 đ̊, 1 \&. West Point, Nebr., L. Bruner ; Ellis, Kansas, Watson (Mus. Comp. Zoöl.).

\section{Ceuthophilus pallidus.}

Ceuthophilus pallidus Thom.!, Ann. Rep. U. S. Geol. Geogr. Surv. Terr., v. 434 (1872); Id., Proc. Dav. Acad. Nat. Sc., i. 264 (1876); Glov., Ill. N. A. Ent., Orth., pl. 18, fig. 18 (1874); Towns., Can. Ent., xxiv. 197-198 (1892); [Ril.], Ins. Life, i. 282-283 (1893); Towns., Ins. Life, vi. 58 (1893).

Body bright luteous, heavily marked with blackish fuscous; on the pronotum the markings are very irregular, but consist in the main of the following: on either side of the front margin a large transverse fuscous spot, which reaches neither the mediodorsal line nor the lateral margin and is interrupted below by a roundish spot and above by the incursion from the anterior margin of a short narrowing dash; in the middle of the dorsum a quadrate spot divided by a mediodorsal luteous line into a pair of longitudinal bars, each connected anteriorly with the before mentioned anterior spot, and leaving a luteous submarginal anterior mediodorsal spot; an infero-posterior black spot not touching the margin; and a laterodorsal subtriangular spot on the posterior margin; on the succeeding thoracic segments, and on the abdominal there is a series of large irregularly triangular laterodorsal spots on the posterior margins, and another lateral series of roundish or transverse spots generally not reaching any margin; the legs are luteous, the fore and middle femora more or less infuscated in longitudinal streaks, the hind femora dull luteous with scalariform fuscous markings. Antennæ moderately slender, about twice the length of the body, the legs moderately long. Fore femora scarcely stouter than the middle femora, less than a fifth longer than the pronotum, much less than half as long as the hind femora, the inner carina with a tolerably long subapical spine sometimes accompanied by another minute one. Middle femora with a long subapical spine on the front carina, accompanied at least in the male by a couple of others smaller, and on the hind carina one or two short spines at least in the male, accompanied by a long genicular spine. Hind femora moderately slender, fully three times as long as broad, two and a third times longer than the fore femora, the surface with a few scattered raised points on the distal half and especially along the upper edge of the inner surface, the outer carina with 6-8 very unequal and inequidistant 
spines, the longest about as long as the tibial spurs (ठ) or wholly unarmed or with a few raised points apically ( $\$$ ), the inner carina very distantly and subequidistautly serrulate, finer in the $\$$ than in the $\delta$, the intervening sulcus moderate. Hind tibiæ straight in both sexes, slightly longer than the femora, armed beneath with a single subapical spine, besides the apical pair; spurs subalternate, the basal near the end of the proximal fourth of the tibia, about half as long again as the tibial depth, set at a varying angle with the tibia, the outer series at least in the $\delta$ being directed outward, the inner series both inward and posteriorly, divaricating about $120^{\circ}$, the tips incurved; inner middle calcaria considerably longer than the outer, more than twice as long as the others or as the spurs, and nearly as long as the first joint of the tarsi. Hind tarsi fully two fifths as long as the tibiæ, the first joint fully as long as the remaining joints together, the second threc times as long as the third and with it as long as the fourth. Cerci very slender and tapering in their distal half, stouter and subequal in their proximal half, scarcely so long as the femoral breadth. Ovipositor about half as long as the hind femora, straight, slender and equal beyond the basal third, the tip produced, acuminate and upturned, the teeth long, aculeate, arcuate.

Length of body, $\delta 15 \mathrm{~mm}$., $\$ 12 \mathrm{~mm}$; pronotum, $\delta \$ 4.5 \mathrm{~mm}$.; fore femora, $\delta 5.25 \mathrm{~mm}$., $\$ 5.1 \mathrm{~mm}$; hind femora, के $12.2 \mathrm{~mm}$., \$ $11.5 \mathrm{~mm}$.; hind tibiæ, ơ $13.1 \mathrm{~mm}$., $\$ 12 \mathrm{~mm}$. ; ovipositor, $5.5 \mathrm{~mm}$.

1 శో, 3 \&. Hot Springs, Dak: ; Denver, Col., Beales ; Las Cruces, N. Mex., C. H. T. Townsend; Silver City, N. Mex., C. H. Marsh ; all through L. Bruner. In the U. S. National Museum, mostly from the Riley collection, are 2 \&, 5 \& , from Laramie and Red Buttes, Wyo., Custer, Colorado (Cockerell), Colorado, and New Mexico. Thomas reported it from S. E. Colorado, Empire, Coi., and Red Buttes, Wyo.; Townsend from Colorado and New Mexico.

\section{Ceuthophilus vinculatus, $\mathrm{sp}$. nov.}

Pale testaceous, nearly uniform, the posterior margins of all the segments infuscated, the apices of the hind femoral geniculations touched with fuscous, and the pronotum more or less blotched with pale fuscous, particularly with a pair of short submedian stripes on the anterior half. Antennæ slender and nearly three times as long as the body, the legs short but not stout. Fore femora distinctly stouter than the middle femora, but very little longer than the pronotum, less than half as long as the hind femora, the inner carina with a preapical spine. Middle femora with 1-4 spines on the inner carina, and on the 
hind carina 1-2 spines besides the genicular spine. Hind femora moderately stout, tapering regularly to the very tip with no pregenicular contraction, considerably more than twice as long as the fore femora, less than three times as long as broad, glabrous, with no raised points on any part, the outer carina pretty uniformly and finely serrate, especially in apical balf, the inner carina similarly but more sparsely serrate, the intervening sulcus narrow except distally. Hind tibiæ straight in both sexes, slender, no wider in the middle than at base, equal to or scarcely so long as the hind femora, armed beneath with one or two preapical spines besides the apical pair ; spurs subopposite, not so long as the tibial depth, set at an angle of about $45^{\circ}$ with the tibia and divaricating at even a less angle. the extreme tips incurved; inner middle calcaria scarcely longer than the outer, nearly twice as long as the others or as the spurs, and much shorter than the first joint of the tarsi. Cerci rather stout, tapering, about two thirds as long as the femoral breadth. Ovipositor rather stout and uniformly tapering on the basal half, uniform and slender on the distal half, somewhat longer than the fore femora, the extreme tip prolonged to a spine, the teeth of the inner valves aciculate, arcuate.

Length of body, $\delta 12 \mathrm{~mm}$., \& $13 \mathrm{~mm}$.; antennæ, के (est.) $30 \mathrm{~mm}$; pronotum, of $3.75 \mathrm{~mm}$., ? $3.6 \mathrm{~mm}$; fore femora, o $4.2 \mathrm{~mm}$., $q 4$ $\mathrm{mm}$; hind femora, of $9 \mathrm{~mm}$., $q 7.65 \mathrm{~mm}$; hind tibix, of $8.5 \mathrm{~mm}$., १ $7.65 \mathrm{~mm}$; ovipositor, $5 \mathrm{~mm}$.

4 đ, 1 \%. Nevada, H. Edwards; North Pacific R. R. Survey below Lake Jessie at Fort Benton, Dr. Suckley. Since description I have received $2 \delta, 5 \%$, from West Point, Lincoln, and Holt Co., Nebraska, from L. Bruner; and have seen in the Museum of Comparative Zoölogy at Cambridge a $\delta$ and $q$ from Santa Barbara, Cal. (Osten Sacken), which apparently belong here, although there are no indications of any transverse banding. There are also $2 \delta$ in the U. S. National Museum from California and Washington, both from the Riley collection.

This species is closely allied to $C$. californianus, but has slenderer hind tibiæ and a longer ovipositor; its general appearance is very similar,

\section{Ceuthophilus testaceus, sp. nov.}

Light fusco-testaceous, with a faint mediodorsal luteous stripe and obscurely dotted with luteous (sometimes obsolete), the lower sides of the body growing gradually pallid luteous, and the pronotum more or less mottled or clouded with fuscous; legs testaceous, sometimes slightly 
infuscated, the hind femora with feeblest possible fuscous scalariform markings. Antennæ very slender, two or three times as long as the body, the legs short. Fore femora slightly broader than the middle femora, a very little longer than the pronotum (relatively longer in the $\$$ than in the $\delta$ ), a little more than half as long as the hind femora, the inner carina with a rather long subapical spine and sometimes an additional one. Middle femora with 2-4, usually three, subequal spines on the front carina, and on the hind carina generally four spines besides a moderately long genicular spine. Hind femora moderately slender, tapering with almost exact regularity to the tip, somewhat more than three times as long as broad, rather less than twice as long as the fore femora, the surface just beyond the middle with very scattered raised points on the whole upper half of the femora outside and inside, both carinæ distantly and delicately serrulate in both sexes, the intervening sulcus narrow. Hind tibiæ straight in both sexes, a very little longer than the femora, at least in the male, slightly enlarged apically as viewed from the side, armed beneath with a single subapical spine besides the apical pair; spurs subalternate, the basal set far before the end of the proximal fourth of the tibia, fully twice as long as the tibial depth, set at an angle of $30-40^{\circ}$ with the tibia and divaricating at not above $90^{\circ}$, their extreme tips scarcely incurved; inner middle calcaria of about the same length as the outer, nearly twice as long as the others and half as long again as the spurs, but shorter than the first joint of the tarsi. Hind tarsi almost half as long as the tibiæ, the first joint as long as the rest together, the second more than twice as long as the third and with it equal to the fourth. Cerci moderately slender, at least as long as the pronotum. Ovipositor slender, straight, tapering at the base, equal from before the middle, longer than the fore femora, the tip produced to an aculeate spine projecting a little upward, the teeth of the inner valves pretty long, aculeate, arcuate.

Length of body, $\delta 10 \mathrm{~mm}$., $\$ 9 \mathrm{~mm}$; pronotum, $\delta 4 \mathrm{~mm}$., $\$ 3.6$ $\mathrm{mm}$; f fore femora, of $4.25 \mathrm{~mm}$., $\$ 4.2 \mathrm{~mm}$; hind femora, $\delta 8 \mathrm{~mm}$., \& $7.7 \mathrm{~mm}$. ; hind tibix, of $8.5 \mathrm{~mm}$., क $7.8 \mathrm{~mm}$.; ovipositor, $4.5 \mathrm{~mm}$.

28,2 \%. West Point, Nebr.; Sheridan, Wyo., C. Y. Smith, all from L. Bruner; St. Louis, Engelmann.

\section{Ceuthophilus californianus.}

Ceuthophilus californianus Scudd.!, Bost. Journ. Nat. Hist., vii. 438 (1862) ; Walk., Cat. Derm. Salt. Brit. Mus., i. 202 (1869).

Ceuthophilus castaneus Thom.!, Rep. U.S. Geol. Geogr. Surv. Terr., 
v. 435 (1872) ; Glov., Ill. N. A. Ent., Orth., pl. 18, fig. 17 (1874); Fletch., Rep. Exp. Farms Can., 1888, 63 (1889).

Ceuthophilus denticulatus Scudd.!, Ann. Rep. Geogr. Surv. West 100th Mer., 1876, 279 (1877).

Varying from light to dark castaneous with very feeble markings, excepting usually a greater or less degree of infuscation along the posterior margins of all the segments and the anterior margin of the pronotum; the pronotum is also sometimes feebly enlivened with vermiculate fuliginous markings and not infrequently a faint luteous line may be traced along the middle of the dorsum, often conspicuous on the pronotum and always slender; the legs are concolorous with the body. The antennæ are rather coarse, tapering throughout uniformly, the eyes small, distinctly smaller than the antennal scrobes, the legs short and stouter than usual. Fore femora distinctly stouter than the middle femora, arched superiorly, about a fifth longer than the pronotum and slightly more than half as long as the hind femora, the inner carina with a single subapical spine besides being minutely serrulate throughout. Middle femora having a variable number of spines but usually $3-4$ on the front carina, and on the hind carina a variable but generally considerable number of minute spines or serrations besides a short genicular spine. Hind femora about two thirds as long as the body $(\delta)$ or a little less than that ( $q)$, almost twice as long as the fore femora, moderately stout, regularly tapering to the very apex with no pregenicular constriction, about three times as long as broad, glabrous, with a few feeble distant raised points above just before the geniculation, the outer carina uniformly and rather delicately serrulate except at base, more feebly in the female than in the male, the inner carina similarly but more delicately serrulate, the intervening sulcus tolerably broad apically but not at base. Hind tibiæ of male straight, unusually stout, on the upper surface twice as broad in the middle as at base, of the same length as the femora, armed beneath with a single preapical spine besides the apical pair; spurs subopposite, about equal to or a little longer than the tibial depth, set at an angle of about $45^{\circ}$ to the tibia and diverging at an angle of $60^{\circ}$ or less with each other, their tips incurved; inner middle calcaria slightly longer than the outer, half as long again as the other calcaria, twice as long as the spurs and nearly as long as the first joint of the tarsus. Hind tarsi nearly half as long as the tibiæ, the first joint nearly as long as the others combined, the second twice as long as the third and with it not so long as the fourth. Cerci rather stout, tapering throughout, not much longer than half the femoral breadth. Ovipositor as long as the pronotum, 
tapering in the basal half, beyond equal, not very slender and straight, the tip strongly upcurved, the armature of the inner valves formed of long, bluntly pointed, arcuate teeth.

Length of body, \& $19 \mathrm{~mm}$. , \& $16.25 \mathrm{~mm}$; antennæ, \& (est.) 40 $\mathrm{mm}$.; pronotum, ơ $5.25 \mathrm{~mm}$., $\$ 4.75 \mathrm{~mm}$.; fore femora, $\delta 6.75 \mathrm{~mm}$., १ $5.3 \mathrm{~mm}$.; hind femora and tibix, each, of $13 \mathrm{~mm}$., \& $10.25 \mathrm{~mm}$; ovipositor $4.75 \mathrm{~mm}$.

19 ठ 4 ९. California (Edwards, Behrens, Crotch, Osten Sacken, Palmer, Bruner), and in particular San Francisco, Pescadero, Gilroy, Sonoma and Marin Counties, Santa Barbara, June, and San Bernardino, Feb.; Beaver Dam, south of St. George, Utah, in the most desert region, April 20-28, E. Palmer; Ehrenberg, Colorado River, Arizona, E. Palmer. It has also been reported from Vancouver Isl. by Walker and Fletcher. In the U.S. National Museum, from the Riley Collection, are $4 \delta$ from California, Martinez, Cal. (Turner), Los Angeles Co., Cal., and no locality (A. E. Brush); also a single $\delta$ with extraordinarily broad hind tibiæ from Alameda Co., Cal.

\section{Cecthophilus latipes, sp. nov.}

Nearly uniform dull luteo-testaceous, with the usual fuscous slender scalariform markings on the hind femora and short longitudinal fuscous dashes on the posterior portions of the abdominal segments, repeated vaguely as cloudy markings on the meso- and metanotum; pronotum slightly infuscated anteriorly and posteriorly. Antennæ moderately slender, the legs exceptionally short. Fore femora distinetly though only slightly stouter than the middle femora, scarcely longer than the pronotum and much less than half as long as the hind femora, the inner carina unarmed. Middle femora with a single preapical spine on the front carina, and on the hind carina a single small spine or none besides a tolerably long genicular spine. Hind femora somewhat shorter than the body, exceptionally broad, about two and a half times longer than broad, almost two and a half times longer than the fore femora, strongly arcuate beneath, strongly and sharply constricted before the geniculation, with a very few raised points on the middle of the inner side above, the outer carina closely serrulate, the inner carina distantly and finely deuticulate, the intervening sulcus moderately broad and uniform. Hind tibiæ with the extreme base briefly arcuate, beyond straight, of the same length as the femora, slender, armed beneath with a single delicate subapical spine (sometimes two) besides the apical pair; spurs opposite, the basal at the end of the proximal third of the tibia, scarcely longer than the tibial breadth, set at an 
angle of about $60^{\circ}$ with the tibia and diraricating about $80^{\circ}$, their tips incurved; inner middle calcaria considerably longer than the outer, fully half as long again as the others or as the spurs, but much shorter than the first joint of the tarsi. Hind tarsi considerably less than half as long as the tibiæ, the first joint hardly so long as the rest together, the second fully twice as long as the third and with it as long as the fourth. Cerci rather stout, tapering rapidly, somewhat shorter than the breadth of the femora.

Length of body, $11 \mathrm{~mm}$; antennæ, 13+ mm. ; pronotum, $3.25 \mathrm{~mm}$.; fore femora, $3.65 \mathrm{~mm}$; hind femora, $9 \mathrm{~mm}$. ; hind tibiæ, $9 \mathrm{~mm}$.

$1 \delta$, Sierra de la Miguelito Mexico, E. Palmer.

\section{Ceuthophilus pacificus.}

Ceuthophilus pacificus Thom., Ann. Rep. U. S. Geol. Surv. Terr., v. 436 (1872); Glov., Ill. N. A. Ent., Orth., pl. 14, fig. 8 (1872).

Ceuthophilus unispinosus Brunn., Monogr. Stenop., 64 (1888).

Luteous, heavily irrorate with more or less confluent fuscous dots, giving it, as Thomas well expresses it, a mossy appearance; the amount of confluence and accordingly of infuscation varies somewhat in different individuals, and is usually deepest on the pronotum, which also often shows on either side a larger or smaller rufo-luteous patch free from dots; the hind femora retain the usual scalariform markings, which are narrower than common. Antennæ moderately stout at base, very slender beyond, three or four times as long as the body. Legs rather short. Fore femora scarcely stouter than the middle femora, about a fourth longer than the pronotum and much less than half as long as the hind femora, the inner carina with a long subapical spine. Middle femora with a long subapical spine on the front carina sometimes accompanied by 1-2 shorter ones, the hind carina with a single subapical spine besides the genicular spine. Hind femora almost as long as the body, considerably more than twice as long as the fore femora, very stout, apically tapering rapidly especially in the $\delta$, the distal fifth subequal, about two and a half times longer than broad $(\delta)$, the darker portions heavily scabrous with raised points: besides a sparse sprinkling of the same on the apical half of the inner surface, the outer carina minutely and bluntly bi- or tri-serrulate, sometimes with a large preapical triangular dentiform spine serrulate on its proximal edge $(\zeta)$ or unarmed $(q)$, the inner carina similar but in the distal half more coarsely uniserrulate, the serration stopping abruptly before the apex with a distinct denticle, sometimes produced to a stout triangular spine, serrulate on the proximal edge $(\delta)$ or with 
a few feeble raised points or spinules on the apical half ( $\$$ ), the intervening sulcus broad and $\mathbf{V}$-shaped. Hind tibiæ strongly and sharply bowed just before the middle, and on the proximal portion prominently and roundly laminate beneath, by reason of the bow no longer than the femora $(\delta)$ or straight and simple, slightly longer than the femora ( $\%$ ), armed beneath with a single preapical spine and an apical pair ; spurs subopposite, the basal pair but little before the middle of the tibia, about as long as the tibial depth, set at an angle of about $45^{\circ}$ with the tibia and divaricating but little more than that, the tips feebly incurved; inner middle calcaria slightly longer than the outer, more than twice as long as the others or as the spurs, and as long as the first tarsal joint. Hind tarsi about two fifths the length of the tibix, the first joint fully as long as the rest together, the second nearly three times as long as the third and almost equal to the fourth. Cerci stout in the basal half, beyond tapering, not more than half as long as the femoral breadth, except in the female. Ovipositor gently tapering in the basal half, slender beyond and finely pointed, scarcely upturned at tip, about two thirds as long as the hind femora, the inner valves feebly and bluntly serrulate apically with no apical hook.

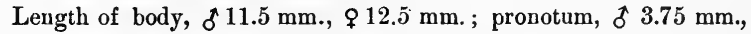
\$ $4.1 \mathrm{~mm}$. ; fore femora, of $4.4 \mathrm{~mm}$., $\$ 5 \mathrm{~mm}$; hind femora, $\delta 10$ mm., \& $11.7 \mathrm{~mm}$; hind tibiæ, of $10 \mathrm{~mm}$., $\$ 12.25 \mathrm{~mm}$; ovipositor, $7.5 \mathrm{~mm}$.

9 §ै, 13 \&. California, P. R. Uhler, J. Akhurst, H. Edwards, Behrens; Nevada, H. Edwards; Mountains about Lake Tahoe, Cal., Oct., H. W. Henshaw in Capt. Wheeler's Expl., 1876. The U. S. National Museum also contains 5 fo, 3 \&, from Martinez, Cal., H. W. Turner, and Los Angeles Co., Coquillet and others, mostly through the collection of $\mathrm{C}$. V. Riley.

The dorsal surface of the abdomen of the male of this species somewhat resembles its next neighbor, $C$. henshawi, in its sculpture, the several segments being somewhat uniformly and rather closely covered with blister-like elevations, largest and closest next the dorsal line. Neither Thomas nor Brunner has noticed this peculiarity.

\section{Ceuthophilus henshawi, sp. nov.}

Mostly brownish fuscous above, but very minutely and abundantly irrorate with lutecus, increasingly so in passing down the sides, so that the luteous prevails on the flanks; the pronotum is also usually marked with a broad prevailingly luteous mesial band, and the mesonotum and metanotum often but not always with a similar broad trans-

vol. $\mathrm{xxx}$. (N. s. $\mathrm{xx11.)}$ 
verse patch above; occasionally in young individuals these thoracic markings are reduced to a narrow mesial luteous stripe; the hind femora are similarly speckled in place of the usual markings, though these sometimes prevail. Antennæ very slender, probably about twice the length of the body. Legs rather short and not stout. Fore femora no stouter than the middle femora, about a fourth longer than the pronotum in the $\delta$, less than that in the $q$, and in both considerably less than half the length of the hind femora, the inner carina with an exceedingly minute preapical spine. Middle femora with 2-3 minute spines (sometimes obsolete in the $\$$ ) on the front carina, and the hind carina similarly armed besides a small genicular spine. Hind femora stout and broad, the lower margin straight by the posterior elevation of the outer carina almost to the geniculation, when it terminates abruptly and subacutely, as long as the body and about three times as long as broad $(\delta)$ or stout and broad, normal, about three fourths as long as the body, with a few raised points clustered above the depressed middle line of the femora $(q)$, the outer carina closely serrulate throughout $(\delta)$ or simple and uxarmed $(q)$. Hind tibiæ abruptly and considerably bent just beyond the base, but still nearly a tenth longer than the femora, beyond the bend nearly straight $(\delta)$, or straight throughout and similarly longer than the femora ( $\$$ ), beneath with a series of raised points and 1-2 recumbent subapical spines besides a preapical and apical pair $(\delta)$ or with a single subapical spine and an apical pair ( $\%$ ) ; spurs subopposite, the basal pair situated not far before the middle of the tibia, no longer than the tibial depth, set at an angle of $45^{\circ}$ with the tibia and divaricating about $90^{\circ}$, their tips incurved; inner middle calcaria considerably longer than the outer, more than twice as long as the others or as the spurs, but shorter than the first tarsal joint. Hind tarsi about one half the length of the hind tibiæ, very slender, the first joint not so long as the rest together, the second fully twice as long as the third, and with it longer than the fourth. Cerci greatly swollen in the basal half, beyond slight, the whole about half as long as the femoral breadth. Ovipositor considerably less than two thirds as long as the hind femora, tapering throughout, the tip pointed but hardly upturned, the inner blades obsoletely serrulate with 7-8 elevations.

Length of body, $\delta \$ 12 \mathrm{~mm}$; antennæ, $\delta$ \% $15+\mathrm{mm}$.; pronotum, $\delta 4 \mathrm{~mm}$., $\$ 3.5 \mathrm{~mm}$; fore femora, $\delta 5.2 \mathrm{~mm}$., $\$ 4 \mathrm{~mm}$; hind femora, o $11.5 \mathrm{~mm}$., $\$ 8.9 \mathrm{~mm}$; hind tibix, of $12.25 \mathrm{~mm}$., $\$ 9.4 \mathrm{~mm}$.; ovipositor, $5.25 \mathrm{~mm}$.

6 §, 2 \&. Sanzalito, Cal., California, Vancouver Isl., Washington, 
II. K. Morrison, coll. S. Henshaw ; $1 \delta, 4$ \%, Oregon, and Placer, Kern, and Los Angeles Counties, Cal., mostly from the Riley collection (U. S. Nat. Mus.).

The male of this species is remarkable for the surface sculpture of the dorsum of the abdomen, the first seven segments of which, but particularly the second to the sixth inclusive, are densely covered with minute strongly .elevated tubercles, besides which on the anterior portion of the first to the fifth segments and almost crossing the segment is a mesial series of large slightly transverse tumid elevations, rounded anteriorly, truncate posteriorly. I have seen nothing resembling it in any other species, excepting to a less degree in its next neighbor, C. pacificus; this and the peculiar characteristics of the outer hind femoral carina make this a very striking species, which I take pleasure in dedicating to my colleague, Mr. Samuel Henshaw.

\section{Cedthophilus devius, sp. nov.}

Nearly uniform brownish testaceous, subglabrous, with very feeble infuscated obscure blotches especially upon the pronotum, and a fine mediodorsal luteous thread runuing the length of the body; surface, especially in $\delta$ and particularly on the thorax, very finely subcorrugate. The antennæ are coarse at base (beyond broken), the joints more or less thickened apically. The legs are rather short. Fore femora much less than half the length of the body, hardly a fifth longer than the pronotum, a little stouter than the middle femora and a little less than half as long as the hind femora, the inner carina with a preapical spine and a few $(q)$ or many $(\delta)$ spinous points; the fore tibiæ with a single median spine on the inner side above, and beneath with $3(q)$ or $4(\delta)$ pairs of stout spines. Middle femora with 5-6 ( $\$$ ) or 8-9 (ठ) spines on the fropt carina, the preapical small, at least in the $\delta$, the hind carina similarly armed and with a small genicular spine. Hind femora considerably shorter than the body, distinctly more than twice the length of the fore femora, nearly straight above in the $\delta$ where they are of nearly equal breadth on the proximal two thirds and are then somewhat abruptly emarginate beneath, less than three and a half times as long as broad in both sexes, the surface glabrous with no raised points excepting sparsely scattered ones on the upper surface in the middle half, the outer carina of both sexes with equal slight denticulations on the constricted portion of the femora, the inner carina with larger denticulations throughout (except at base) much larger and more unequal in the $\delta$, where the largest are as long as the tibial spurs, the inferior sulcus narrow. Hind tibiæ 
straight, of the same length as the femora, stout, basally constricted, beneath with a row of distant spines besides the apical pair ; spurs subopposite, the basal pair at the end of the proximal third of the tibia, scarcely longer than the tibial depth, set at an angle of $45^{\circ}$ with the tibia and divaricating $70-80^{\circ}$; inner middle calcaria but little longer than the outer, about half as long again as the others or as the spurs, shorter than the first joint of the tarsis. Hind tarsi about one third as long as the tibiæ, the first joint scarcely longer than the fourth and less than twice as long as the second and third together, the second but little longer than the third. Cerci rather slender, tapering throughout, pointed, much shorter than the femoral breadth. Ovipositor nearly straight, scarcely longer than the fore femora, the basal half tapering, the apical slender and equal, the tip pretty strongly upcurved to a fine point, the teeth and especially the apical tooth very long, slender, and arcuate.

Length of body, $\delta 17 \mathrm{~mm}$., $\$ 17 \mathrm{~mm}$; pronotum, $\delta 6.25 \mathrm{~mm}$., $5.5 \mathrm{~mm}$.; fore femora, $\delta 7.65 \mathrm{~mm}$., $\$ 6.5 \mathrm{~mm}$.; hind femora and hind tibiæ, each, $\delta 16.25 \mathrm{~mm}$., $\$ 13 \mathrm{~mm}$; ovipositor, $7 \mathrm{~mm}$.

1 \&, 1 \%. Explorations of the Upper Missouri and Yellowstone under Lt. Warren, F. V. Hayden. I also find in the U. S. National Museum from the Riley collection $1 \delta, 2 \$$, from Nebraska, the Platte River, Nebr. (McCarthy), and Ft. Riley, Kans.

By the brevity of the first and second hind tarsal joints and the slight enlargement of the fore tibiæ in the male, this species approaches the genus Phrixocnemis, but the normal development of the armature of the hind tibiæ forbids placing it there.

\section{Ceuthophilus neomexicanus, sp. nov.}

Dark testaceous or castaneous, glabrous, broadly but gradually infuscated, especially above, on the posterior margins of all the segments, and on the anterior portion of the pronotum, which is otherwise more or less slightly mottled, beneath and on the lower portions of the sides invariably lighter and generally more nearly unicolorous. Legs testaceous, the hind femora externally with a feeble median longitudinal infuscation sometimes visible only on the distal half, where it is often diffused and accompanied by feeble slender herring-bone infuscations on either side, the hind tibial spines feebly infuscated at apex. The antennæ are not very slender and the legs short. Fore femora distinctly stouter than the middle femora, but little longer than the pronotum and less than half as long as the hind femora, the inner carina with a subapical spine, sometimes accompanied at variable 
distances by a smaller one. Middle femora with 1-4 spines on the front carina, most numerous in the $q$ and the subapical the largest, the hind carina similarly armed, but one spine genicular and the others as numerous in the $\delta$ as in the $\delta$. Hind femora much shorter than the body, considerably more than twice as long as the fore femora, stout, being in the $\delta$ less than three times as long as broad, with hardly any subapical constriction, that is, tapering almost regularly to the apex, the surface with no raised points, the outer carina pretty regularly and rather minutely denticulate in the distal half or less, exclusive of the geniculation $(\delta)$, or minutely denticulate throughout (\$), the inner carina similar to the outer, but in the $\delta$ more extensively denticulate than the outer, the intervening sulcus narrow. Hind tibiæ straight in both sexes, distinctly shorter than the femora, the upper surface rather broad in the $\delta$ and basally constricted, beneath with a longer $(\delta)$ or shorter (q) series of median spines, besides the apical pair; spurs subopposite, the basal pair at the end of the proximal third of the tibia $(\delta), *$ about as long as the tibial depth $(\delta)$, or two to three times as long as the tibial depth (\&), set at an angle of about $50^{\circ}$ $(\delta)$ or $30^{\circ}(q)$ with the tibia and divaricating as much, their tips scarcely incurved; inner middle calcaria not greatly longer than the outer, less than half as long again as the others or as the ( $\delta$ ) spurs, nearly as long as the first tarsal joint. Hind tarsi much less than two fiftls as long as the tibia, the first joint not so long as the rest together, the second but little longer than the third and with it a little shorter than the fourth. Cerci rather slender and regularly tapering, pointed, considerably shorter $(\delta)$ or considerably longer $(q)$ than the hind femoral breadth. Ovipositor about two thirds as long as the hind femora, its upper margin feebly arcuate, the apical two thirds subequal, the apex slightly upturned and very acuminate, the teeth of the inner valves long, aciculate, the distal arcuate.

Length of body, \& $12 \mathrm{~mm}$., \& $11.5 \mathrm{~mm}$.; pronotum, \& $3.5 \mathrm{~mm}$., \& $3.25 \mathrm{~mm}$; fore femora, $\delta 4 \mathrm{~mm}$., $\$ 3.6 \mathrm{~mm}$. ; hind femora, $\delta 8.75$ mm., \& $7.6 \mathrm{~mm}$; hind tibix, of $8.3 \mathrm{~mm}$., $\$ 7.25 \mathrm{~mm}$; ovipositor, $5.2 \mathrm{~mm}$.

4 §, 1 \&. Ft. Wingate, N. Mex. (Shufeldt), U. S. Nat. Mus.

The species is most nearly allied to $C$. devius, from which it differs principally in its smaller size and the armature of the femora.

* The single $q$ I have seen has four pairs of spurs on one tibia, the basal pair at the end of the proximal fourth of the tibia, while the other tibia has but a single non-opposite pair in the middle of the tibia. It is further anomalous in the excessive length of the spurs, in contrast to the $\delta$. 
The following species have not been seen by me.

\section{Ceuthophilus scabripes.}

Phalangopsis scabripes Hald., Proc. Acad. Nat. Sc., Philad., vi. 364 (1853); Walk., Cat. Derm. Salt. Brit. Mus., i. 116 (1869).

Rhaphidophora scabripes Scudd., Proc. Bost. Soc. Nat. Hist., viii. 7 (1861).

Ceuthophilus scabripes Scudd., Bost. Journ. Nat. Hist., vii. 436 (1862); Walk., Cat. Derm. Salt. Brit. Mus., i. 201 (1869).

I cannot find any species which corresponds sufficiently with Haldeman's description to apply this name to it. When we are better acquainted with the forms occurring in the South, west of the Alleghanies, we may be able accurately to fix it. It was described from Selma, Alabama.

\section{Ceuthophilus utahensis.}

Ceuthophilus utahensis Thom., Proc. Dav. Acad. Nat. Sc., i. 264, pl. 36, fig. 8 (1876).

None of the species I have seen can be referred to this. It seems to resemble $C$. valgus. It comes from Mt. Nebo, Utah. (See Appendix.)

Note. - Ceuthophilus cubaensis Walk. (Locusta Rhaphidophora cubensis De Haan), of Cuba, is a Pherterus, according to Bolivar and Brunner, belonging to the Anostostomata.

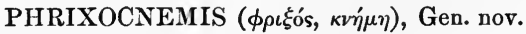

Closely allied to Ceuthophilus, and having its general aspect, though the legs are stouter than is commonly the case in that genus. Head rather large, the vertex well rounded and deflexed, barely interrupted from continuation into the frontal costa by the confluence of the antennal scrobes. Eyes small, subpyriform, as large as the antennal scrobes. Antennæ as in Ceuthophilus. Palpi very small, the antepenultimate joint but little shorter than those on either side of it. Pronotum sub-semicylindrical, the inferior margin of the descending lateral lobes arcuate, the anterior and posterior angles equally or almost equally rounded; those of the meso- and metanotum similarly rounded without the posterior oblique truncation common in Ceuthophilus, or present in the slightest degree. Anterior coxæ compressed and elevated to form a median denticle. Legs short and rather stout. Fore femora stout, or at least broad by compression. Middle femora unarmed apically, or, when armed, only by an inferior and brief spine 
on the posterior side, the genicular lobes very small. Hind femora very broad and incrassate, even the extremity stout, both inferior carinæ feebly denticulate, rarely with any conspicuous spines. Fore tibiæ unarmed above, enlarged in the male; middle tibiæ armed above with several pairs of spines besides those beneath ; hind tibiæ stout, no longer than hind femora, armed beneath with a single apical spine besides the apical pair and above with lateral spines of two classes: a larger series of generally long stout spines, longer than the calcaria, and, especially in the $\$$, becoming longer and more crowded apically, the 4-6 spines of one row not greatly divergent from those of the other; and minute denticulations occupying the interspaces, at least on the proximal half of the tibia and the proximal free portion, but, at least in the $\&$, commonly absent from the distal half of the tibia; the three pairs of apical calcaria are not widely different in length. Hind tarsi short, much less than half as long as the tibiæ, the first and fourth joints, and the second and third joints, respectively subequal, the latter together much shorter than either of the others. Ovipositor equal in breadth throughout, when viewed laterally scarcely or not tapering in the basal hale.

\section{Table of the Species of Phrixocnemis.}

Hind tibiæ of male strongly bowed; distal hind tibial spurs of male as widely separated as the proximal . . . . . truculentus. Hind tibiæ of male straight or almost straight; distal hind tibial spurs of male much more closely approximated than the proximal.

Nearly uniform in coloring; vertex at tip, between upper bases of antennæ, bituberculate; four pairs of hind tibial spurs in the male . . . . . . . . . . . . . . validus.

Distinctly particolored; vertex at tip, between upper bases of antennæ, not bituberculate; five pairs of hind tibial spurs in the male . . . . . . . . . . . bellicosus.

\section{Phrixocnemis truculentus, sp. nov.}

Extreme apex of vertex with a slight depression. Body glabrous, pale luteous, becoming rufo-luteous on the dorsum, where it is heavily marked with blackish or blackish fuscous, particularly on the posterior margins of the segments, the abdominal segments almost wholly brownish fuscous with only an anterior luteous stripe, the meso- and metanotum more rufo-luteous than blackish fuscous, and the pronotum rufo-luteous above, luteous on the sides, with heavy fuscous markings, 
particularly an anterior bordering not reaching the lower margins and thrusting back subdorsal stripes which are broadly separated by rufoluteous, all of which is sometimes very obscure; legs luteous, the hind femora externally tinged with rufo-fuliginous, in which fuscous scalariform markings more or less feebly appear. The antennæ are moderately slender and the legs short. Fore femora considerably stouter than the middle femora, as long as $(\delta)$ or less than a fifth louger than (q) the pronotum, and considerably less than half as long as the hind femora, the inner carina with two or three feeble denticulations; fore tibiæ subullate, considerably stouter than the middle tibiæ. Middle femora with 1-3 short spines on the front carina, the hind carina with 4-5 very short but not very slight spines ( $\delta$ ) or 1-2 feeble denticulations ( $\$)$, besides a very short inferior depending genicular spine, at least in the $\%$. Hind femora much shorter than the body, but considerably more than twice as long as the fore femora, stout and heavy, being in the $\delta$ about two and a half, in the $q$ about two and three quarters time as long as broad, with a rather strong pregenicular constriction beneath in the $\delta$, the upper carinate margin of the inner surface with a series of distant denticulations, the outer carina almost angularly elevated in the middle, armed, mostly beyond the middle, with a strong serration and just before the genicular lobes with a short arcuate compressed rather blunt triangular spine, serrate on its proximal edge, as long as the tibial depth, followed by a nearly similar but smaller tooth upon the genicular lobe $(\delta)$ or with a post-median spine much shorter than the shortest tibial spurs, another pregenicular spine of smaller size, and between them 6-8 spinules ( $\$$ ), the inner carina with a uniform series of raised points ( $\hat{\delta}$ ), , or with small denticulations throughont, similar to these of the outer carina but with no large spines ( $q)$, the intervening sulcus moderate. Hind tibiæ strongly and pretty regularly bowed $(\delta)$ or faintly arcuate $(\$)$, triquetral, deeper than broad, only three fourths ( $\$$ ) or a little more than three fourths $(\delta)$ the length of the hind femora, armed beneath with a single preapical spine besides the apical pair; spurs subopposite, in the $\delta$ four pairs in number, the basal at about the end of the proximal third of the tibia, markedly increasing in length toward the tarsi, so that the proximal are only half as long as the distal, the middle ones slightly longer than the tibial depth, set at an angle of about $70^{\circ}$ with the tibia and divaricating about $45^{\circ}$; in the $q$ six pairs in number, the basal placed before the end of the proximal fourth of the tibia and just beyond a slight but distinct constriction of the tibia, the distal series as long again as the proximal, the inner series a 
little longer than the outer, the shortest not exceeding in length the tibial depth, the proximal more recumbent than the distal and therefore set at an angle with the tibia varying from $40^{\circ}$ to $75^{\circ}$, divaricating $20^{\circ}-30^{\circ}$, the whole faintly incurved; inner middle calcaria of $\delta$ scarcely longer than the others or than the distal spurs and much shorter than the first tarsal joint; calcaria of $\uparrow$ subequal but decreasing in length from above downward, those of opposite sides subequal, the longest no longer than the shortest tibial spurs and much shorter than the first tarsal joint. Hind tarsi about two fifths as long as the tibiæ, the first and fourth joints subequal, and either nearly twice as long as the second and third, which again are subequal, and all but the last apically produced beneath in the $q$ to a spinous point. Cerci slender, tapering regularly, about three fourths as long as the femoral breadth. Ovipositor short, hardly as long as the fore femora, straight, broad even at apex, the extreme upper tip of which is feebly produced; teeth of inner valves aculeate, arcuate.

Length of body, \& $15 \mathrm{~mm}$., $\$ 16 \mathrm{~mm}$; pronotum, of $5 \mathrm{~mm}$., \& 4.5 $\mathrm{mm}$; f fore femora, of $5 \mathrm{~mm}$., $\& 5.25 \mathrm{~mm}$; hind femora, of $12.5 \mathrm{~mm}$., \$ $11.25 \mathrm{~mm}$.; hind tibiæ, $\delta 10.5 \mathrm{~mm}$., $\$ 8.5 \mathrm{~mm}$; ovipositor, $5 \mathrm{~mm}$.

2 o, 1 \&. Peru, Nebr., Professor Townsend; Colorado, July, Suow, Coll. Univ. Kans., - all through L. Bruner.

\section{Phrixocnemis validus, sp. nov.}

Nearly uniform testaceous, glabrous, with feeble infuscation in clouds upon the sides of the pronotum, and to a scarcely perceptible degree upon the whole dorsum, made more evident by a fine mediodorsal luteous thread down the whole body, the legs of the body color, but the apical half of the femora more or less though at most feebly infuscated and the hind femora tipped narrowly with fuscous; the hind femora have also a faint rufous tinge. The antennæ are moderately stout and probably at least three times as long as the body, and the legs short and stout, the vertex rudely bituberculate. Fore femora distinctly stouter than the middle femora, a sixth longer only than the pronotum and half as long as the hind femora, the inner carina furnished with a row of minutest denticles but with no subapical spine. Middle femora with three subequal spines on the front carina, the hind carina unarmed and apparently with no genicular spine. Hind femora very much shorter than the body, twice as long as the fore femora, very stout, being not over two and a half times longer than broad, with only two or three raised points on the inner edge of the upper surface beyond the middle, the outer and inner carinæ similarly armed 
with minute denticulations, the intervening sulcus not broad. Hind tibiæ considerably shorter than the femora, straight, stout, armed beneath with a single small preapical spine, besides the unusually long apical pair; the four pairs of spurs are opposite or subopposite, the basal near the end of the proximal third of the tibia, regularly increasing in length distally, so that the last are as long as the nearest calcaria, while the proximal are but little more than half that length or than the tibial depth, set at an angle of $70-80^{\circ}$ with the tibia and divaricating only about $20^{\circ}$, the whole feebly incurved, the tips not more so; the spurs are also more closely crowded on the distal half of the tibia than before it, and indeed so crowded as to have no intervening spines, which even between the others are few in number and irregular, the two distal spurs with the proximal calcaria being at uniform distances apart, a distance hardly one half that which separates the preceding spurs; all the calcaria are subequal in length, those of opposite sides similar, but they decrease slightly from above downwards, and the longest is as long as the first to third tarsal joints combined. Hind tarsi hardly more than a third as long as the tibiæ, the first and fourth joints subequal and either of them much longer than the subequal second and third joints combined. Cerci moderately stout, equal and single jointed in proximal half, tapering pointed and multiarticulate beyond, the whole about as long as the width of the hind femora.

Length of body, $15 \mathrm{~mm}$; antennæ, $29+\mathrm{mm}$. ; pronotum, $4.3 \mathrm{~mm}$.; fore femora, $5 \mathrm{~mm}$; hind femora, $10 \mathrm{~mm}$; hind tibiæ, $9 \mathrm{~mm}$.

1 d. California, H. Edwards.

\section{Phrixocnemis bellicosus, sp. nov.}

Vertex smooth. Rather bright luteo-testaceous, subglabrous, very broadly marked with blackish fuscous especially in a broad anterior bordering to the pronotum, and a broader or narrower posterior bordering to all the segments, relatively broader on the abdominal than on the thoracic segments, but on the latter sometimes reinforced by a stout mediodorsal stripe deeper in color posteriorly than anteriorly; the interior edges of the anterior and posterior borderings of the pronotum are very irregular, and particularly show subdorsal posterior thrusts of the anterior, and laterodorsal anterior thrusts of the posterior bordering; the lower borders of the thoracic segments are broadly luteous and immaculate; the legs are luteous, the femora infuscated more or less especially beyond the middle, the hind pair with more or less distinct scalariform markings. The antennæ are slender and about three times as long as the body, and the legs short. Fore 
femora distinctly stouter than the middle femora, very little longer than the pronotum and much less than half as long as the fore femora, the inner carina, at least in the male, with a couple of minute subapical spines; fore tibiæ much stouter in the $\delta$ than in the $\$$. Middle femora with two $(\delta)$ or $0-1(\%)$ spines on the frout carina, the hind carina quite unarmed, even wanting a genicular spine. Hind femora about two and a third times longer than the fore femora but much shorter than the body, very stout, being about two and three quarters times longer than broad (narrower in the $\$$ ), the upper surface with 3-4 raised points on its inner edge, the outer carina in the male elevated, arcuate, with about eleven subequal small triangular spines in the distal half, in the female hardly elevated with similar but very feeble spinules, the inner carina with a series of smaller denticulations, the intervening sulcus narrow, but in the male deep. Hind tibiæ very stout, much shorter than the femora, broadly and faintly arcuate, but in the female this is scarcely perceptible, armed beneath with a single subapical spine besides the apical pair; the five $(\delta)$ or six ( $\$$ ) pairs of spurs are subalternate, the basal at about the end of the proximal fourth of the tibia, increasing in length from the first to the penultimate, the ultimate and the three calcaria then decreasing in reverse order, the proximal not much more than half as long as the distal and much shorter than the tibial deptl, the distal spurs more closely crowded than the proximal, and lacking between them the few and irregular spines of the second order found between the proximal, all set at an angle of $60-70^{\circ}$ with the tibia and divaricating $20-30^{\circ}$ only, the whole feebly incurved, their tips perhaps slightly more; calcaria of opposite sides subequal, the longest (uppermost) shorter than the first tarsal joint. Hind tarsi much less than half as long as the tibix, the first and fourth joints subequal and either of them more than twice as long as the subequal second and third joints together. Cerci slender and no longer than the width of the hind femora. Ovipositor slender and of uniform width excepting a slight apical expansion, about as long as the hind tibiæ, the tip acutangulate, at an angle of about $40^{\circ}$, slightly upturned, the inner valves crenato-denticulate with four projections which face posteriorly.

Length of body, \& $11.5 \mathrm{~mm}$. , $\$ 9.5 \mathrm{~mm}$; antennæ, of $31+\mathrm{mm}$., \& (est.) $18+\mathrm{mm}$; pronotum, of $4 \mathrm{~mm}$., $\$ 3 \mathrm{~mm}$.; fore femora, o $4.3 \mathrm{~mm}$., $\$ 3.35 \mathrm{~mm}$; hind femora, of $9.9 \mathrm{~mm}$., $\& 8 \mathrm{~mm}$.; hind tibiæ, of $8.5 \mathrm{~mm}$., $\$ 6 \mathrm{~mm}$. ; ovipositor, $6 \mathrm{~mm}$.

$1 \delta, 1$. Colorado, H. K. Morrison, the $\delta$ at an elevation of $7,000^{\prime}$, the $q$ at one of $5,000^{\prime}$ (the $\delta$ therefore probably in the Ute Pass, the $\$$ on the plains between Denver and Colorado Springs). 


\section{DAIHINIA Haldeman.}

Daihinia Hald., Proc. Amer. Assoc. Adv. Sc., ii. 346 (1850); Girard, Marcy Expl. Red River, 257 (185̃3); Scudd., Bost. Journ. Nat. Hist., vii. 443 (1862). Not Daihinia Sauss., Orth. Nova Amer., i. 14-15 (1859).

This genus is remarkable for lacking the third tarsal joint of the fore and hind legs. Brunner (Monogr. Stenop., 60, foot-note) presumed this to be an abnormal condition found in a single specimen seen by me; but it was seen and specially remarked upon both by Haldeman and Girard before me, and I have examined fourteen specimens of both sexes, all of which agree in this particular except that in two or three of them the fore or hind tarsi, or both, are broken, so that it cannot be affirmed of them. There can be no question that it is normal as no specimen of the two species has been found in which the condition was different.

\section{Table of the Species of Daihinia.}

Hind femora of male about two and a half times longer than broad, armed with 3-4 very large spines on the apical half of the outer carina much larger than the others, the inner carina much more feebly armed; hind tibiæ armed beneath with a single subapical spine . . . . . . . . . . . . . . . brevipes.

Hind femora of male fully three times as long as broad, the spines of the outer carina nearly uniform and much less prominent than those of the inner carina; hind tibiæ armed beneath with a row of spines . . . . . . . . . . . . . gigantea:

\section{DAIHINIA BREVIPFS.}

Phalangopsis (Daihinia) brevipes Hald.!, Proc. Amer. Assoc. Adv. Sc., ii. 346 (1850); Walk., Catal. Derm. Salt. Brit. Mus., i. 116 (1869).

Daihinia brevipes Girard, Marcy Expl. Red River, 257, pl. 15, figs. 9-13 (1853) ; Id., Ibid., 246, pl. 15, figs. 9-13 (1854); Scudd.!, Bost. Journ. Nat. Hist., vii. 443, fig. 3ab (1862); Walk., Catal. Derm. Salt. Brit: Mns., i. 205 (1869) ; Glover, Ill. N. A. Entom., Orth., pl. 7, figs. 14, 15 (1872) ; Brunn., Monogr. Stenop., 60 (1888); Brun., Publ. Nebr. Acad. Sc., iii. 31 (1893).

Upper waters of the Red River of Arkansas (Girard), Platte River above Ft. Laramie, Wyo. (Haldeman, Scudder); Sand Hills, Western Nebraska, and other points in Nebraska, as Sugar Cañon and Thed- 
ford, Thomas Co. (Bruner); Ft. Hays, Ellis Co., Kans., J. A. Allen (Mus. Comp. Zoöl.) ; Ellis, Kansas, Watson (Mus. Comp. Zoöl.); Kansas (Bruner); Black Hills, South Dakota (E. P. Austin); a specimen was also obtained during the Pacific R. R. Surveys under Lt. E. G. Beckwith, U. S. A., near Lat. $38^{\circ}$, presumably in Southern Colorado, and it was taken by Snow in Colorado (Bruner). The species therefore extends along the eastern margin of the Rocky Mts. from Lat. $34^{\circ}$ to $44^{\circ} \mathrm{N}$.

\section{Daininia gigantea.}

Daihinia gigantea Brun.!, Bull. Washb. Coll., i. 127 (1885); i. 195 (1886).

Udeopsylla gigantea Brun.!, Can. Ent., xxiii. 39 (1891); Id., Publ. Nebr. Acad. Sc., iii. 31 (1893).

Labette and Berber Cos., Kans. (Bruner). Bruner also reports it to be found in Nebraska and the Indian Territory.

Note. - Daihinia mexicana Sauss. is not a Daihinia, nor one of the Ceuthophili, but has been placed by Brunner in the genus Glaphyrosoma among the Anostostomata

\section{UDEOPSYLLA SCUDDER.}

Udeopsylla Scudd., Bost. Journ. Nat. Hist., vii. 442 (1862) ; Brunn., Monogr. Stenop., 59 (1888).

\section{Table of the Species of Udeopsylla.}

Body piceous, occasionally with faint rufous spots . . . nigra. Body varying in color from dark testaceous to mahogany brown.

robusta.

\section{UDEOPSYlla NIGRA.}

Udeopsylla nigra Scudd.!, Can. Nat., vii. 284-285 (1862); Id.!. Bost. Journ. Nat. Hist., vii. 443, fig. 2 (1862) ; Walk., Catal. Derm. Salt. Brit. Mus., i. 205 (1869); Thom., Rep. Geol. Geogr. Expl. Surv. 100th Mer., v. 902 (1875) ; Broadh., Trans. St. Louis Acad. Sc., iii. 345 (1876) ; Caulf., Rep. Ent. Soc. Ont., xviii. 63, 69 (1886) ; Brun., Bull. Washb. Coll., i. 195 (1886); Brunn., Monogr. Stenop., 60 (1888) ; McNeill, Psyche, vi. 27 (1891); Osb., Proc. Iowa Acad. Sc., i. ii. 119 (1892) ; Brun., Publ. Nebr. Acad. Sc., iii. 31 (1893); Blatchl., Proc. Ind. Acad. Sc., 1892, 153 (1894).

Ceuthophilus niger Scudd.!, Bost. Journ. Nat. Hist., vii. 437 (1862); Walk., Catal. Derm. Salt. Brit. Mus., i. 202 (1869); McNeill, Psyche, vi. 27 (1891); Blatchl., Proc. Ind. Acad. Sc., 1892, 153 (1894). 
The specimens described by me as a Ceuthophilus belong to this species, though separately described at the same time.

Specimens are recorded as having been taken, or bave been seen by me, from Perry Co., Ill., Dr. E. R. Boardman (Uhler); Illinois (Uhler, Comstock, McNeill); Southern Illinois and Rock Island, Ill. (Uhler); Red River, Manitoba (Caulfield); Carbery, Manitoba, in the gizzard of a sparrowhawk (Fletcher); Northern Minnesota, leaping about in the grass at midday (Scudder); Denison, Crawford Co., Iowa, July 13, 15, 20 (J. A. Allen); Iowa (Osborn); Nebraska City and the Platte Valley, Nebr. (F. V. Hayden); Nebraska City, West Point, and Pine Ridge, Nebr. (Bruner); Northeast Nebraska (Bruner) ; Berber Co., Kans., and Topeka, Kans., Cragin (Bruner); Missouri (Broadhead); Sedalia, Mo. (U. S. Nat. Mus.); Dakota (Bruner), and Colorado, 5,000' (Morrison); so that its general range appears to be between the Mississippi River or a little east of the main stream to the Rocky Mountains between Lat. $37^{\circ}$ and $50^{\circ}$ North. But I have two specimens in my collection, one from North Carolina (Shute), the other from El Dorado Co., Calif., 4,000' (Gissler), both of them far beyond the otherwise known limits of the species. Of the latter locality I entertain no doubt, especially as I have recently found in the Museum of Comparative Zoölogy a single specimen collected by Morrison in Arizona; but as to the former I am inclined to believe the label became accidentally attached to the wrong insect, particularly as Shute's collection was made on the seaboard.

\section{Udeopsylla Robusta.}

Phalangopsis (Daihinia) robustus Hald.!, Proc. Amer. Assoc. Adv. Sc., ii. 346 (1850) ; Walk., Catal. Derm. Salt. Brit. Mus., i. 117 (1869).

Daihinia robusta Girard, Marcy Expl. Red River, 1853, 257; $1854,246$.

Udeopsylla robusta Scudd.!, Bost. Journ. Nat. Hist., vii. 442 (1862); Walk., Catal. Derm. Salt. Brit. Mus., i. 205 (1869); Pack., Guide Ins., 565 (1869) ; Thom., Proc. Acad. Nat. Sc. Philad., 1870, 77; Glov., Rep. [U. S.] Dep. Agric., 1871, 79 ; Thom., Ann. Rep. U. S. Geol. Surv. Terr., ii. 265 (1871), v. 437 (1872); Scudd.!, Rep. U. S. Geol. Surv. Nebr., 249 (1872); Glov., Ill. N. A. Ent., Orth., pl. 8, fig. 9 (1872) ; Scudd.!, Ann. Rep. Geogr. Surv. West 100th Mer., 1876, 279 ; Thom., Bull. U. S. Geol. Geogr. Surv. Terr., jv. 485 (1878) ; Scudd.!, Rep. U. S. Ent. Comm., ii. App. 23 (1881); Brun., Bull. Washb. Coll. i. 127 (1885); Brunn., Monogr. Stenop., 59-60, 
fig. 31 (1888) ; Osb., Proc. Iowa Acad. Sc., i. ii. 119 (1892); Brun., Publ. Nebr. Acad. Sc., iii. 31 (1893).

Udeopsylla compacta Brun.!, Can. Ent., xxiii. 38-39 (1891); Id., Publ. Nebr. Acad. Sc., iii. 31 (1893).

Specimens have been seen by me from Clifford, N. Dak. (Bruner), explorations in Dakota under Gen. Sully (Rothhammer); Sheridan, Wyo. (Bruner); Ft. Fettermann, Wyo. (U. S. Nat. Mus.); above Ft. Laramie, Wyo.; Denison, Crawford Co., Iowa, July 15 (J. A. Allen); Holt Co., Pine Hills, Lincoln, and Broken Bow, Nebr. (Bruner); Nebraska City and the banks of the Platte (Hayden); Nebraska (P. R. Uhler and Miss Walker); Republican River, Nebr. or Kans. (W. T. Wood); Syracuse, Kans. (U. S. Nat. Mus.); Pacific R. R. Surveys, Lat. $38^{\circ}$ (Lt. Beckwith); Colorado (U. S. Nat. Mus.); Albuquerque, N. Mex., Wickham (Bruner); Texas (Uhler); Pasadena, Cal. (Bruner). From the same States or Territories it has also been reported as follows: Dakota and Wyoming (Thomas); Holt and Wheeler Cos., Nebr. (Bruner), New Mexico (Bruuer, Scudder), and Texas (Brunner). It has also been credited to the following: Montana, Southern Idaho, and Bloomington, Ill., - the last probably in error (Thomas); Missouri (Bruner); Bourbon Co., Kans. (Bruner); Colorado (Scudder); and "open sections of the Rocky Mt. region" (Thomas); besides Utah (Glover, Thomas).

\section{GAMMAROTETTIX BRUNNER.}

Gammarotettix Brunn., Monogr. Stenop., 60, 61 (1888).

\section{Gammarotettix Bilobatus.}

Ceuthophilus bilobatus Thom.!, Ann. Rep. U. S. Geol. Surv. Terr., v. 437 (1872).

Gammarotettix californicus Brunn., Monogr. Stenop., 61, fig. 32 (1888).

California (Brunner, Behrens); Marion and Sonoma Cos., Cal. (Osten Sacken) ; Lakeport, Lake Co., Gilroy, Santa Clara Co., Chrystal Springs, San Mateo Co., and San Diego, Cal. (Crotch); Santa Cruz Mts., Santa Clara Co., Los Angeles Co., Cal. (U. S. Nat. Mus.). 


\section{APPENDIX.}

After this paper was in type, I received from the Davenport Academy of Natural Sciences, through the kind intervention of Prof. Herbert Osborn, of Ames, Iowa, the single type of Ceuthophilus utahensis Thom. (see p. 102), and append a description of it to render this paper more complete. It is not so closely related to $C$. valgus as I had supposed from the description and figure, but belongs rather in the near vicinity of $C$. uhleri and C. blatchleyi, though with the inferior sulcus of the hind femora not so exceptionally broad as in those species, and also with very different markings, in which respect it recalls rather C. pallidus. The measurement of the hind tibiæ given by Thomas is too great. The specimen was collected in alcohol, but has since been pinned.

Brownish fuscous with dull luteous markings; on the pronotum the fuscous borders all the margins broadly, the anterior and lateral margins very broadly, sending backward from in front a broad mediodorsal stripe nearly meeting the posterior bordering, and through it runs a faint median luteous thread; the posterior bordering throws forward on either side a subdorsal tooth embracing the posterior end of the mediodorsal stripe and leaving between the two a $U$-shaped luteous mark which connects the luteous disks of either side, the latter of which are more or less mottled with fuscous lines; the meso- and metanotum are heavily spotted anteriorly with partly confluent luteous spots, and the abdominal segments are more regularly margined anteriorly with luteous; legs warm luteous, the hind femora with the usual scalariform infuscations. The antennæ are moderately slender and more than twice, probably thrice, as long as the body, and the legs moderately long. Fore femora no stouter than the middle femora, a little less than half as long as the hind femora, scarcely more than a third longer than the pronotum, the inner carina with a moderately long preapical spine preceded by a shorter one. Middle femora with a single moderately long spine on the front carina and on the hind carina 1-2 short spines besides a moderate genicular spine. Hind femora nearly as long as the body, somewhat more than twice as long as the fore femora, moderately stout, only the distal sixth subequal, about three and a quarter times as long as broad, the surface with a very few raised points along the upper edge of the inner side, the outer carina considerably and subequally elevated, with about fifteen coarse but rather small subequal and inequidistant spines, the longest 
not a third as long as the tibial spurs, the inner carina with a series of rather distant short spinules partially biseriate, the intervening sulcus broad, equal, and deep. Hind tibiæ rather feebly and broadly sinuate (this point is exaggerated in the original figure), a very little longer than the femora, armed beneath with a single long preapical spine besides the apical pair; spurs subalternate, the basal beyond the end of the proximal third of the tibia, nearly twice as long as the tibial depth, set at an angle of about $35^{\circ}$ with the tibia and divaricating about $80^{\circ}$, their apical third or fourth considerably incurved; inner middle calcaria considerably longer than the outer, fully twice as long as the others or as the spurs, but somewhat shorter than the first tarsal joint. Hind tarsi about two fifths as long as the tibiæ, the first joint as long as the rest together, the second and fourth subequal, and each about twice as long as the third. Cerci rather stout, tapering regularly, about as long as the femoral breadth.

Length of body, $14.5 \mathrm{~mm}$. ; antennæ, $31+\mathrm{mm}$; pronotum, $4.4 \mathrm{~mm}$.; fore femora, $6 \mathrm{~mm}$; hind femora, $13 \mathrm{~mm}$.; hind tibix, $13.5 \mathrm{~mm}$.

1 ð. Mt. Nebo, Utah, August, Putnam (Dav. Acad. Nat. Sc.).

July 20, 1894.

voL. $\mathrm{xxx}$. (N. S. $\mathrm{xxII.)}$ 






\section{Date Due}

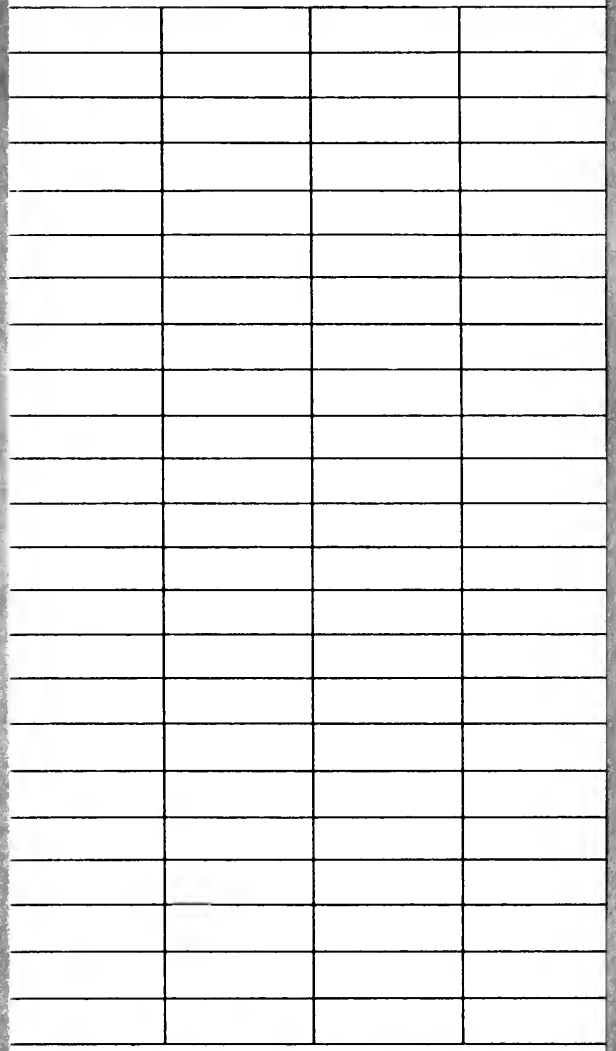

PRINTEDIN U.s.A. CAT. NO. 24161 


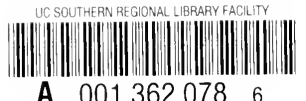

A 0013620786 
